MARIA CAROLINA TAVARES GERALDINO 

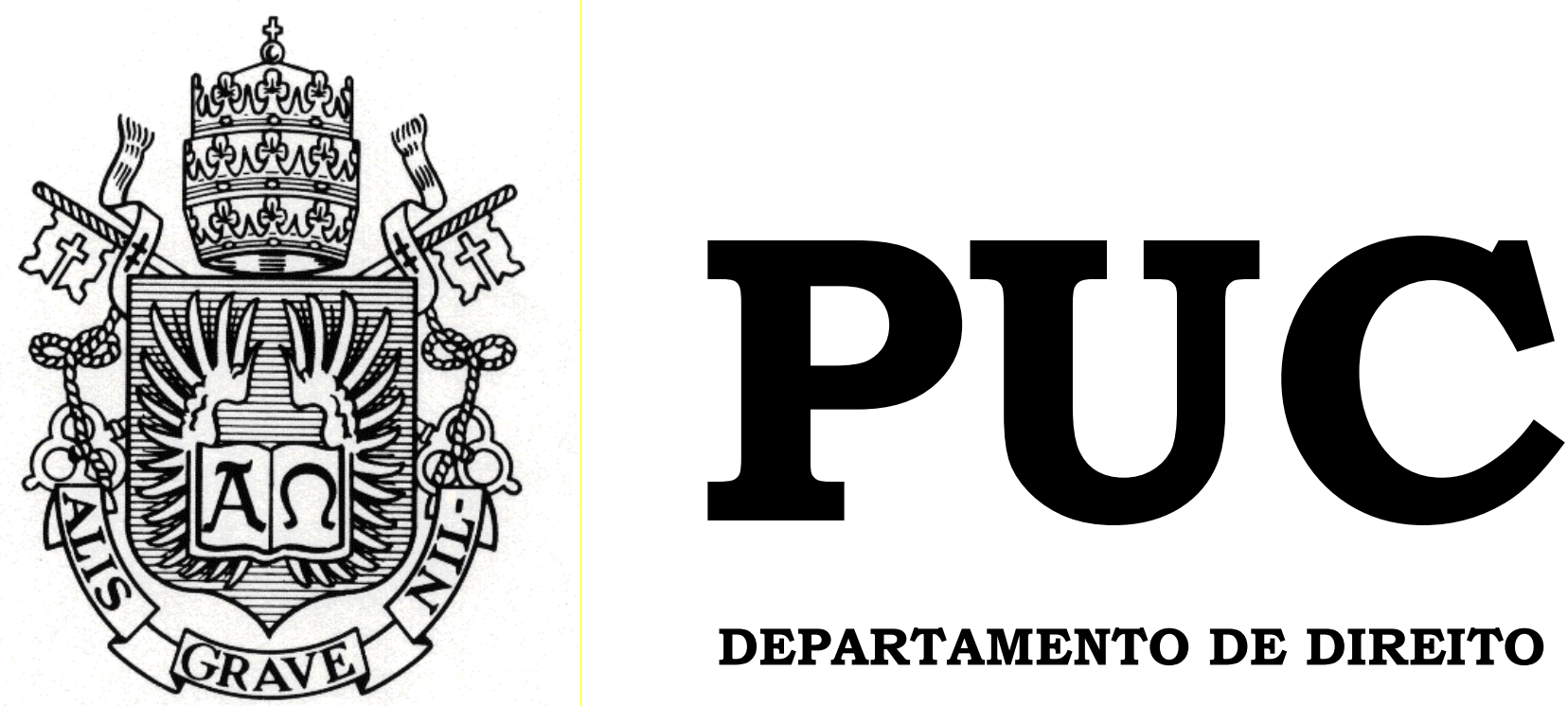

DEPARTAMENTO DE DIREITO

\section{DIREITOS FUNDAMENTAIS: CONFLITOS E PONDERAÇÃO}

por

MARIA CAROLINA TAVARES GERALDINO

ORIENTADORA: REGINA COELI LISBÔA SOARES

2010.1

PONTIFÍCIA UNIVERSIDADE CATÓLICA DO RIO DE JANEIRO

RUA MARQUÊS DE SÃO VICENTE, 225 - CEP 22453-900

RIO DE JANEIRO - BRASIL 


\title{
DIREITOS FUNDAMENTAIS: \\ CONFLITOS E PONDERAÇÃO
}

\author{
por
}

MARIA CAROLINA TAVARES GERALDINO

Monografia apresentada ao

Departamento de Direito da Pontifícia Universidade Católica do Rio de Janeiro (PUC-Rio) para a obtenção do Título de Bacharel em Direito.

Orientadora: Regina Coeli Lisbôa Soares 
À meus pais, por permitirem a realização de todos os meus sonhos. 


\section{Agradecimentos}

Agradeço, inicialmente, à professora Regina Soares, que atenciosa e generosa, aceitou orientar-me, incentivou a escolha do tema, e fez comentários preciosos para o desenvolvimento do trabalho.

Ao professor J. J. Gomes Canotilho por gerar em mim o interesse pelo tema, por ter me auxiliado nos primeiros passos deste trabalho, e por toda a atenção dispensada aos alunos Erasmus.

Aos professores de graduação da PUC-Rio, pelo conhecimento partilhado durante esses anos de curso.

À meus pais, Moacyr e Elizabeth, e ao meu irmão, Pedro, sem os quais eu jamais teria a possibilidade de cursar essa universidade, por me ensinarem as coisas mais preciosas desta vida, por incentivarem todos os meus sonhos, pelo amor e carinho incondicional, e aos quais terei eterna gratidão.

À meu namorado, Delcídio, que sempre ao meu lado, me ajudou a passar pelos momentos de dúvida e ansiedade e me fez acreditar que todos os meus sonhos são possíveis, agradeço mais do que posso expressar, pelo apoio incondicional. Pela privação de momentos preciosos devido à minha formação, na certeza de que passaremos juntos toda uma vida.

À minha tia, Belkiss, minhas primas, Luana, Renata e Raizza, e à Zeca, agradeço a acolhida carinhosa e as palavras de conforto sempre que a saudade de casa falava forte.

À meu sogro, Olegário, que carinhosamente cuidou das correções desta monografia, e à minha sogra, Fátima, por todo carinho e atenção durante todos esses anos. 
"O homem deve abraçar a justiça e marchar destemidamente, tornando-se, assim, sustentáculo da comunidade, baluarte contra o mal social e construtor de uma sociedade sadia, porque Deus não deixará de ajudar os justos, como jamais deixou."

Mokiti Okada 


\section{Resumo}

O presente trabalho busca ressaltar a temática dos conflitos de direitos fundamentais, identificando-os e buscando apresentar as possíveis soluções desse tipo de conflito de normas que por sua especificidade não pode ser solucionado com base nos métodos hermenêuticos tradicionais e com o uso do raciocínio subsuntivo.

Assim, após a apresentação da estrutura normativa dos direitos fundamentais, ressaltando a divisão entre regras e princípios, adentra-se na análise dos conflitos, diferenciando a concorrência de direitos fundamentais da colisão de direitos fundamentais em sentido amplo e em sentido estrito e estreitando-se suas características e limites.

Diante da apresentação desses diferentes tipos de conflito, busca-se identificar os possíveis meios de solução das colisões de direitos fundamentais, apresentando e ressaltando as principais vicissitudes de cada uma das técnicas comumente estudadas pela doutrina e, adotando uma posição favorável à utilização da técnica da ponderação de interesses como técnica que se apresenta como mais apta a solucionar de forma racionalmente controlável essas colisões.

Por fim, apresentam-se os limites que devem permear a técnica ponderativa para evitar que sejam perpretados subjetivismos e arbitrariedades com sua utilização.

\section{Palavras chave}

Regras; princípios; conflito de direitos fundamentais; concorrência de direitos; colisão de direitos em sentido amplo; colisão de direitos em sentido estrito; hierarquização; categorização; limites imanentes; ponderação; concordância prática; lei de colisão; lei de sopesamento; motivação; proporcionalidade; razoabilidade; núcleo essencial dos direitos fundamentais. 


\section{Sumário}

Introdução

\section{Capítulo I - Direitos fundamentais e sua estrutura normativa:}

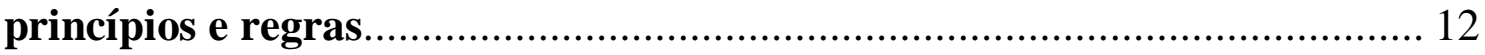

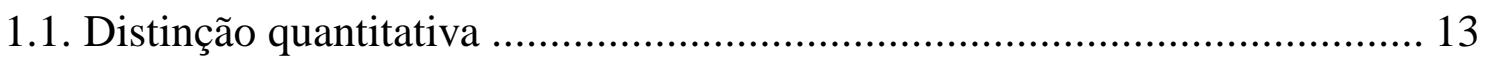

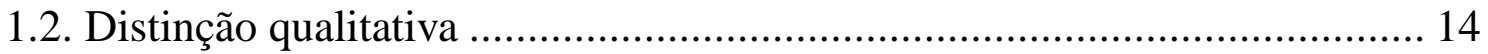

1.2.1. Crítica a distinção qualitativa: a possibilidade da ponderação de

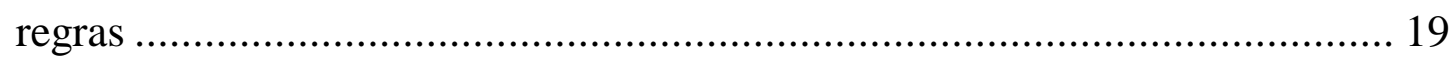

1.3. Outras distinções...................................................................... 23

1.4. A teoria dos princípios e os direitos fundamentais ............................... 24

1.4.1. modelo puro de regras ............................................................... 24

1.4.2. modelo puro de princípios .................................................... 26

1.4.3. modelo misto de príncipios e regras ................................................ 27

Capítulo II - Conflito de direitos fundamentais..................................... 29

2.1. Tipos de conflito de direitos fundamentais ......................................... 33

2.1.1. Concorrência de direitos fundamentais .......................................... 33

2.1.2. Colisão de direitos fundamentais em sentido estrito.......................... 34

2.1.3. Colisão de direitos fundamentais em sentido amplo .......................... 35

2.2. Os hard cases e o método da subsunção.............................................. 36

2.3. A colisão de direitos fundamentais e a atuação dos três poderes ................ 38

2.4. Métodos de resolução dos conflitos ................................................... 40

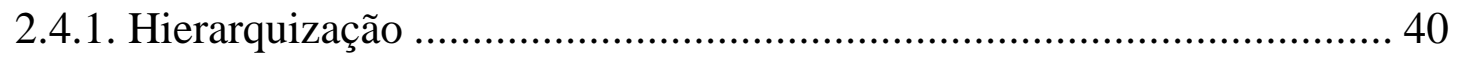

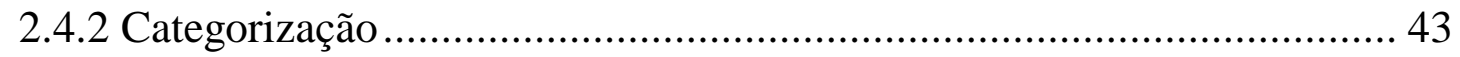

2.4.3 Limites Imanentes ................................................................ 45

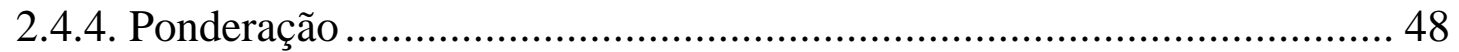

2.4.4.1. Conceito de ponderação ..................................................... 48

2.4.4.2. Teoria da concordância prática........................................... 52

2.4.4.3. Ponderação em abstrato e ponderação em concreto ...................... 54 
2.4.4.4. Proposta de ponderação em três etapas........................................... 57

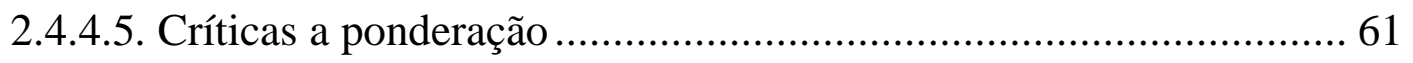

2.4.4.6. A lei de colisão e a lei de sopesamento de Robert Alexy como

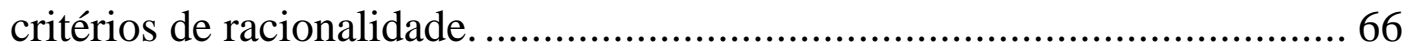

2.4.4.7. Motivação das decisões ponderativas............................................ 70

Capítulo III - Limites à ponderação de direitos fundamentais ..................... 73

3.1. Razoabilidade e proporcionalidade.......................................................... 73

3.2. A proporcionalidade e sua estrutura tripartite ……….................................. 74

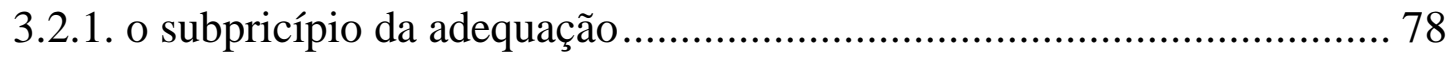

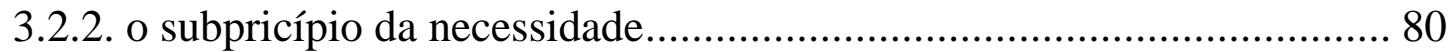

3.2.3. o subpricípio da proporcionalidade em sentido estrito........................... 81

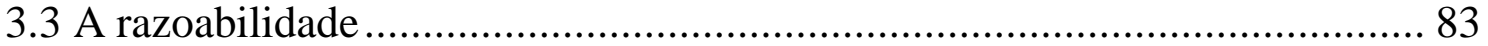

3.4. O núcleo essencial dos direitos fundamentais............................................ 85

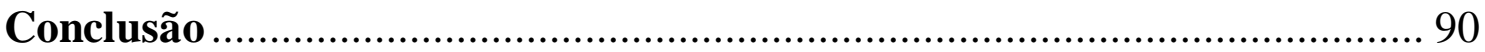

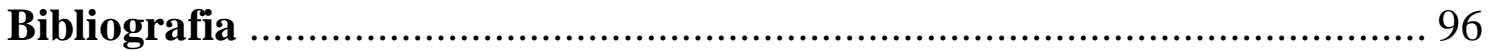

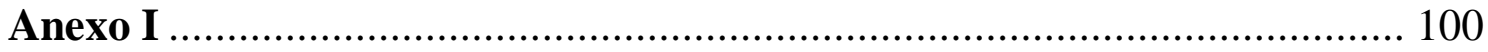

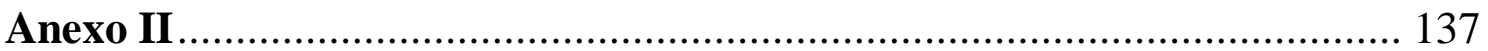




\section{Introdução}

O surgimento dos conflitos de direitos fundamentais está completamente ligado à análise histórica da passagem do modelo jurídico positivista para o modelo pós-positivista.

Explica-se: com a superação do ideal positivista, surgiu uma nova ordem jurídica que abrange conceitos valorativos e princípios que são inseridos no ordenamento jurídico. Assim, essas normas principiológicas, por sua natureza aberta, permitem uma colisão com outros direitos e princípios também consagrados, como insta demostrar.

$\mathrm{O}$ ideal positivista tentou trazer uma purificação para o direito, ou seja, pretendeu construir uma teoria pura do direito, livre de qualquer valoração social, econômica, moral, etc. Esta pretensão de pureza buscou afastar do direito qualquer processo valorativo e até a questão da justiça foi excluída do ramo da ciência jurídica ${ }^{1}$.

Deste modo, no mundo positivista, o direito se reduzia a norma, não importando o texto em si e sim o procedimento de criação da norma. Para considerar a validade de uma norma os positivistas não analisavam seu conteúdo; procuravam apenas analisar se a norma, em sua criação, seguiu corretamente os procedimentos previstos em lei.

O papel do juiz também se encontrava limitado no ideal positivista. O exegeta era visto como mera "boca da lei", não cabendo a ele interpretar ou valorar normas e sim apenas declarar as normas aplicáveis ao caso. O método da subsunção era visto como método único de aplicação das normas; não havia qualquer juízo sobre o caso concreto ou à justiça da

\footnotetext{
${ }^{1}$ BARROSO, Luis Roberto, ao definir o positivismo jurídico ressalta esse pensamento ao salientar que para o positivismo "a ciência do Direito, como todas as demais, deve fundar-se em juízos de fato, que visam ao conhecimento da realidade, e não em juízos de valor, que representam uma tomada de posição diante da realidade. Não é no âmbito do direito que se deve travar a discussão acerca de questões como legitimidade e justiça". Interpretação e aplicação da constituição: fundamentos de uma dogmática constitucional transformadora. 6. ed. rev., atual. e ampl. São Paulo: Saraiva, 2004.p.323.
} 
norma, estando o exegeta fadado a realizar apenas um raciocínio subsuntivo, de mera aplicação da norma aos fatos.

A partir da Segunda Guerra Mundial, e com a difusão dos modelos fascistas e nazistas, o método positivista começa a ser questionado, pois a análise apenas procedimental das normas permitiu a perpetuação e legalização de verdadeiras barbáries. Assim, surge o movimento chamado de pós-positivista que parte em busca de um religamento entre direito e moral, da análise de justiça das normas, da normatização dos princípios e da ampliação do papel do julgador.

Essa nova visão do direito, representada no constitucionalismo moderno, busca reaproximar o direito da moral e, assim, os valores, que representam a ideologia e os fins da sociedade, transformam-se em princípios e estes são inseridos na Constituição adquirindo normatividade e tornando-se a base de todo o ordenamento jurídico ${ }^{2}$.

Passamos, então, a uma Constituição valorativa e repleta de princípios que consagra valores de conteúdo bastante difuso, por permitirem variações no tempo, no espaço e principalmente diante das circunstâncias do caso concreto.

Aliado a isto, adoção brasileira de uma Constituição compromissória tenta representar uma sociedade plural e consagra ideais, opções e interesses diversos, antagônicos e possivelmente colidentes.

Como consequência desta nova realidade jurídica o papel do juiz teve de ser redesenhado, para, assim, permitir uma correta aplicação da Constituição. $\mathrm{O}$ exegeta adquire um papel mais interpretativo, passando a analisar as situações do caso concreto e a justiça da norma. Diante de interesses conflitantes cabe a ele manter e consagrar a unidade constitucional, preservar os valores ali consagrados e determinar os limites de conceitos abertos.

\footnotetext{
${ }^{2}$ BONAVIDES, Paulo. Curso de Direito Constitucional. 13 ${ }^{\mathrm{a}}$ ed. São Paulo: Malheiros Editores, 2003. Capítulo 8.
} 
É certo que no mundo contemporâneo tudo parece complexo, cada problema a ser analisado importa em variados pontos de vista e reflete valores e interesses diversos e muitas vezes conflitantes. Os problemas tornam-se ainda maiores e as decisões cada vez mais complexas quando ambos os interesses em conflito estão consagrados na ordem constitucional.

Verifica-se que a Norma Fundamental deve ser aplicada como um todo harmônico, mas que, por outro lado, consagra valores e interesses conflitantes que se opõem em diversas situações. Deste modo, a busca por soluções elimina os métodos hermenêuticos tradicionais e tenta a construção de uma técnica alternativa capaz de solucionar tais conflitos mantendo a unidade constitucional e que seja racionalmente controlável.

Para muitos essa técnica é representada pela ponderação de interesses. No entanto, essa consideração deve ser investigada e alguns questionamentos podem ser suscitados. No que consiste a técnica ponderativa? Seria ela realmente um meio apto a resolver os conflitos de direitos fundamentais? Como se dá seu funcionamento? Como fazer para limitar subjetivismos e permitir o controle racional da ponderação? Existem outras técnicas que se demonstrem como alternativas viáveis e até melhores que a técnica da ponderação?

Responder a estas questões e estudar os conflitos de direitos fundamentais e a aplicação da técnica ponderativa, suas particularidades, vicissitudes e limites é o objetivo deste estudo. 


\section{Capítulo I - Direitos fundamentais e sua estrutura normativa: princípios e regras}

Para a melhor compreensão do presente trabalho, torna-se necessária uma primeira distinção entre regras e princípios, ressaltando seus aspectos mais relevantes, facilitando assim o entendimento do tema a ser abordado. Essa diferenciação servirá como uma linha instrutora para toda a discussão acerca dos conflitos de direitos fundamentais.

A análise estrutural das normas de direitos fundamentais reveste-se de grande importância no estudo dos conflitos de direitos fundamentais, sendo a base para a solução de diversos problemas hermenêuticos que se apresentam no desenvolver do tema.

O eminente jurista alemão Robert Alexy já ressalta a fundamentabilidade desta distinção:

"Essa distinção é a base da teoria da fundamentação no âmbito dos direitos fundamentais e uma chave para a solução de problemas centrais da dogmática dos direitos fundamentais. Sem ela não pode haver nem uma teoria adequada sobre as restrições a direitos fundamentais, nem uma doutrina satisfatória sobre colisões, nem uma teoria suficiente sobre o papel dos direitos fundamentais no sistema jurídico."

A influência desta distinção reside no fato de que os direitos fundamentais são ora classificados como regras, ora como princípios. $\mathrm{Na}$ maioria dos casos, encontramos uma classificação dos direitos fundamentais como princípios, ressaltando sua carga valorativa e abertura semântica. Porém, quando se quer ressaltar a necessidade de entender a Constituição e sua aplicação como lei ou quando se trata da possibilidade de fundamentação dedutiva, os direitos fundamentais são tratados como regras. Sendo assim, torna-se necessária uma distinção precisa que permita diferenciar as regras dos princípios e enquadrar de forma correta os direitos fundamentais.

\footnotetext{
${ }^{3}$ ALEXY, Robert. Teoria dos Direitos Fundamentais. Traduzido por Virgílio Afonso da Silva. São Paulo: Malheiros Editores, 2008. p. 85.
} 
Essa distinção não é nova e apresenta uma abordagem polêmica e imprecisa, existindo uma infinidade de critérios distintivos.

Primeiramente, devemos considerar que ambos: regras e princípios, são espécies de normas jurídicas. Isto porque ambos traduzem juízos de dever-ser e expressam enunciados de permissão, proibição e dever ${ }^{4}$, servindo para disciplinar condutas e constituindo bases de decisões judiciais.

Essa classificação nem sempre foi assim considerada. Antes a metodologia jurídica tradicional realizava uma distinção entre normas e princípios, tratando-os como categorias distintas, porém, devido às concepções de Ronald Dworkin e aos desenvolvimentos de Robert Alexy, pacificou-se o entendimento de que os princípios, ao lado das regras, são espécies de normas.

Nos dias atuais as atenções estão voltadas principalmente para as distinções entre regras e princípios, bem como para as metodologias adotadas para tratar cada um dos tipos de normas. Tendo em vista essa discussão, Robert Alexy dividiu em duas categorias as distinções entre regras e princípios, uma qualitativa ou lógica e outra quantitativa ou de grau, as quais trataremos a seguir.

\subsection{Distinção quantitativa}

Essa distinção de regras e princípios baseia-se na idéia de que a diferença entre as espécies de norma é apenas quantitativa ou de grau, não existindo diferenças lógicas ou qualitativas.

Os adeptos deste tipo de distinção consideram os princípios como as normas mais fundamentais do sistema, sendo superiores em generalidade e abstração.

\footnotetext{
${ }^{4}$ ALEXY, Robert defende essa tese ao afirmar que "Tanto regras quanto princípios são normas, porque ambos dizem o que deve ser. Ambos podem ser formulados por meio das expressões deônticas básicas do dever, da permissão e da proibição". Teoria dos Direitos Fundamentais. Traduzido por Virgílio Afonso da Silva. São Paulo: Malheiros Editores, 2008. p. 87.
} 
Sendo assim, princípios e regras teriam como distinção determinante o seu grau de generalidade, posto que o dos princípios seria elevado enquanto que o das regras seria relativamente baixo.

Nesse sentido Norberto Bobbio define os princípios como "normas fundamentais ou generalíssimas do sistema, as normas mais gerais. ",

De acordo com essa distinção, os princípios seriam tendencialmente mais abstratos, incidindo sobre diversas situações, enquanto as regras seriam concretas, contendo um relato objetivo e voltado para incidir sobre situações específicas reguladas por elas.

Para os partidários deste modo de diferenciação os princípios norteiam uma grande diversidade de situações, sendo considerados diretrizes gerais do ordenamento jurídico enquanto as regras têm um conteúdo mais objetivo, cuidando de casos concretos.

Alexy, que considera essa distinção a mais comumente utilizada, classifica-a como a distinção fraca entre regras e princípios.

\subsection{Distinção qualitativa}

Em busca de melhores critérios de diferenciação entre regras e princípios foram criadas distinções baseadas no modos de interpretação e aplicação das duas categorias normativas.

Sendo assim, com base nas concepções de Ronald Dworkin e nos desenvolvimentos à sua teoria realizados por Robert Alexy foi desenvolvido um critério de diferenciação baseado em diferenças qualitativas ou lógicas entre regras e princípios.

O início dessa discussão é devido a Ronald Dworkin ao criticar o modelo positivista e sua forma de atuação.

$\mathrm{O}$ autor norte americano não concorda com o modo de concepção positivista no qual na ausência de regras aplicáveis ao caso o juiz pode criar novas regras baseado em sua discricionariedade. Sendo assim, promove

\footnotetext{
${ }^{5}$ BOBBIO, Norberto. Teoria do ordenamento jurídico. 5.ed. Brasília. DF.: UnB, 1994. p.158.
} 
duras críticas a esse metódo, fundamentando que nesse caso deveria ser utilizado o recurso aos princípios jurídicos e afirmando que o modelo subestima a importância que os princípios assumem no ordenamento jurídico, principalmente na solução dos chamados casos difíceis (hard cases). ${ }^{6}$ Nesse sentido afirma:

"Em minha argumentação afirmarei que, mesmo quando nenhuma regra regula o caso, uma das partes pode, ainda assim, ter o direito de ganhar a causa. O juiz continua tendo o dever, mesmo nos casos difíceis, de descobrir quais são os direitos das partes, e não de inventar novos direitos retroativamente."7

E arremata ao concluir que "se o caso em questão for um caso difícil, em que nenhuma regra estabelecida dita uma decisão em qualquer direção, pode parecer que uma decisão apropriada possa ser gerada seja por princípios, seja por politicas. ,8

Partindo deste pressuposto, Dworkin inicia uma diferenciação entre princípios e regras determinando que aqueles diferem destas em estrutura e lógica por constituirem pontos de aproximação entre o direito e a moral e terem assim uma forma diferenciada de aplicação. Para ele o princípio seria "um padrão que deve ser observado, não porque vá promover ou assegurar uma situação econômica, política ou social considerada desejável, mas porque é uma exigência de justiça ou equidade ou alguma outra dimensão da moralidade,"9.

Essa ligação entre o direito e a moral traz para o direito a possibilidade de valorações subjetivas, contrariando a tese positivista que prega a total separação entre Direito e Moral.

Considera ainda que ambas estruturas normativas são "standarts" utilizados para disciplinar condutas, apontando para decisões particulares, porém diferem na orientação estabelecida. Isso porque as regras seriam aplicadas no modelo do tudo ou nada, ou seja, seriam aplicadas de forma completa ou não seriam aplicadas ao caso. Se os dados estipulados pela

\footnotetext{
${ }^{6}$ DWORKIN, Ronald. Levando os direitos a sério. São Paulo: Martins Fontes, 2007. Cap. 4

${ }^{7}$ DWORKIN, Ronald. Levando os direitos a sério. São Paulo: Martins Fontes, 2007. p.71.

${ }^{8}$ DWORKIN, Ronald. Levando os direitos a sério. São Paulo: Martins Fontes, 2007. p.131.

${ }^{9}$ DWORKIN, Ronald. Levando os direitos a sério. São Paulo: Martins Fontes, 2007. p.36
} 
regra se aplicarem ao caso então ela é válida e deve ser utilizada, caso contrário a regra não se aplicaria ao caso.

Já os princípios, por não estabelecerem consequências diretas para o aparecimento de determinadas condições, seriam aplicados de outra forma, eles teriam infindáveis formas de aplicação, pois apenas apontam uma direção a se seguir, sem determinar soluções específicas.

Por outro lado, os princípios teriam uma dimensão própria, não presente nas regras jurídicas, a dimensão de peso e importância. Devido a essa dimensão no caso de um conflito entre princípios, deve-se levar em conta a força relativa de cada um dos envolvidos, para assim formar a decisão perante aquele caso concreto. Nesses casos um dos princípios deve ceder diante do outro, mas isso não significa considerar que o princípio que cede seria inválido e sim que no caso concreto os princípios têm diferentes pesos e importância e que deve prevalecer o que for maior nessas dimensões, demandando assim juízos subjetivos nessa determinação.

Já o conflito de regras seria resolvido na instância da validade, por critérios de natureza formal, ou seja, se existem regras colidentes uma delas seria considerada inválida e não se aplicaria ao caso, no modelo do tudo ou nada.

O téorico alemão Robert Alexy desenvolveu a teoria de Dworkin, adotando uma tese bastante compatível com a de seu antecessor, porém com algumas diferenças a serem consideradas.

Alexy questiona o modelo de aplicação das regras (tudo ou nada) adotado por Dworkin ao vislumbrar a possibilidade de ser inserida na regra, diante do caso concreto, uma nova cláusula de exceção não antes prevista, de forma que permitiria deste modo manter a regra como válida. Nesse caso, a inserção de uma exceção na aplicação da regra, a faria perder seu caráter definitivo, e não seria possível enumerar todas as exceções passíveis de aplicação, como pretendia Dworkin. 
O ponto decisivo de diferenciação entre regras e princípios é assim determinado por Alexy:

\begin{abstract}
"O ponto decisivo na distinção entre regras e princípios é que princípios são normas que ordenam que algo seja realizado na maior medida possível dentro das possibilidades jurídicas e fáticas existentes. Princípios são, por conseguinte, mandamentos de otimização, que são caracterizados por poderem ser satisfeitos em graus variados e pelo fato de que a medida devida de sua satisfação não depende somente das possibilidades fáticas, mas também das possibilidades jurídicas. $\mathrm{O}$ âmbito das possibilidades jurídicas é determinado pelos princípios e regras colidentes.

Já as regras são normas que são sempre ou satisfeitas ou não satisfeitas. Se uma regra vale, então, deve se fazer exatamente aquilo que ela exige; nem mais, nem menos. Regras contêm, portanto, determinações no âmbito daquilo que é fática e juridicamente possível. Isso significa que a distinção entre regras e princípios é uma distinção qualitativa, e não uma distinção de grau. Toda norma é ou uma regra ou um princípio". ${ }^{10}$
\end{abstract}

Essa consideração dos princípios como mandamentos de otimização define sua aplicação conforme as determinantes do caso concreto (possibilidades fáticas) e conforme as regras ou princípios que estejam colidindo com ele (possibilidade jurídica). Considerando essas variantes, deve-se buscar a realização dos princípios na melhor medida possível e para isso, utiliza-se o instrumento da ponderação.

A determinação mais importante do autor é a possibilidade de os princípios serem cumpridos em diferentes escalas, sendo assim comandos prima facie, que podem ser ampliados ou restingidos conforme a situação do caso concreto e as razões a eles opostas. Já as regras estariam caracterizadas como comandos definitivos que ao se conferirem determinadas condições determinariam consequências jurídicas definitivas.

Em razão dessa estrutura peculiar, a principal e mais relevante demostração da diferença entre regras e princípios ocorreria no caso das colisões entre princípios e dos conflitos entre regras, ou seja, nos casos em que duas normas poderiam ser aplicadas levando a soluções incompatíveis entre si.

No caso do conflito de regras, Alexy propõe duas soluções: ou introduz-se uma cláusula de exceção em uma das regras, possibilitando

\footnotetext{
${ }^{10}$ ALEXY, Robert. Teoria dos Direitos Fundamentais. Traduzido por Virgílio Afonso da Silva. São Paulo: Malheiros Editores, 2008. p.90 e 91.
} 
assim sua convivência e eliminando o conflito, ou declara-se uma das regras inválida com base em um dos critérios para a solução de antinomias, quais sejam, cronológico (lei posterior derroga a anterior naquilo que for incompatível), hierárquico (lei superior revoga a inferior se com ela for incompatível) e da especialidade (lei especial revoga a geral).

Na sua ótica "o conceito de validade jurídica não é graduável. Ou uma norma jurídica é válida, ou não é. Se uma regra é válida e aplicável a um caso concreto, isso significa que também a sua consequência jurídica é válida. Não importa a forma como sejam fundamentados, não é possível que dois juízos concretos de dever-ser contraditórios entre si sejam válidos.". 11

A colisão entre princípios propugna uma solução completamente diversa, sendo determinante que nesse caso um dos princípios terá que ceder total ou parcialmente perante o outro na solução do caso concreto. Essa situação não se compatibiliza nem com a inclusão de uma cláusula de exceção, nem com a declaração de invalidade do princípio cedente. $\mathrm{Na}$ realidade, o que ocorre é a determinação de precedência de um princípio sob o outro, perante as especificidades do caso concreto, e essa determinação é feita com base na ponderação dos pesos dos princípios conflitantes perante a situação desenvolvida.

Percebemos assim que o conflito de regras é solucionado na dimensão de sua validade, enquanto que a colisão de princípios na dimensão do valor.

As formulações feitas por Ronald Dworkin e Robert Alexy são de extrema importância na distinção das regras e princípios, possibilitando uma distinção precisa entre as categorias normativas. Essa distinção ligada a critérios qualitativos ou lógicos foi definida por Alexy como a distinção forte entre regras e princípios.

\footnotetext{
${ }^{11}$ ALEXY, Robert. Teoria dos Direitos Fundamentais. Traduzido por Virgílio Afonso da Silva. São Paulo: Malheiros Editores, 2008. p. 92
} 


\subsubsection{Crítica à distinção qualitativa: a possibilidade da ponderação de regras}

Diante de fenômenos recentes, parte da doutrina passou a considerar a possibilidade de também as regras serem objeto de ponderação, devido à utilidade prática que essa aplicação traria para casos concretos.

Nesse sentido, manifestou-se Humberto Ávila ao afirmar que " $a$ ponderação diz respeito tanto aos princípios quanto às regras, na medida em que qualquer norma possui um caráter provisório que poderá ser ultrapassado por razões havidas como mais relevantes pelo aplicador diante do caso concreto. $" 12$

A discussão resvala na dificuldade de se classificar as normas como regras e princípios e nos questionamentos relativos às limitações trazidas por essa classificação, ou seja, discute-se se a insersão de uma norma como regra ou como princípio deve limitar sua forma de aplicação, permitindo a ponderação apenas para aquelas qualificadas como princípios.

Como foi demonstrado, a lógica ponderativa está relacionada à estrutura dos princípios de forma que estes podem ser comprimidos, não sendo aplicados completamente, porém mantendo sua validade, apenas com uma variação de intensidade. Discute-se assim a possibilidade de adaptação desse modelo para o âmbito das regras.

Por vezes as regras permitem que se realize uma interpretação na definição de seus sentidos, sendo estes os casos nos quais as regras possuem conceitos indeterminados. Sendo assim, se há um conflito entre regras esse pode ser superado pelo sentido dado ao conceito indeterminado, não sendo necessária a utilização do método ponderativo. Excetuando-se esse caso, torna-se complexo conceber a aplicação mais ou menos restrita de regras.

\footnotetext{
${ }^{12}$ ÁVILA, Humberto. Teoria dos princípios: da definição à aplicação dos princípios jurídicos. 4. ed. rev. São Paulo: Malheiros, 2004. p.50.
} 
A aplicação da ponderação no âmbito normativo das regras pode levar a não aplicação de uma regra que seria aplicável e pertinente ao caso concreto, gerando assim uma situação de ruptura do sistema do Estado de direito.

Duas são as hipóteses de ponderação de regras levantadas pela doutrina.

Primeiramente, considera-se que uma regra poderá ser ponderada se sua incidência perante o caso concreto produzir uma situação de injustiça considerada intolerável. Nessa situação, muitas vezes, devido à amplitude da noção de justiça, considera-se que existe um conflito entre regras e princípios inseridos no ordenamento jurídico, justificando assim a utilização de um método ponderativo.

Um exemplo desse tipo de aplicação pode ser vislumbrado em uma decisão do Supremo Tribunal Federal ao considerar a aplicação da norma que define o estupro com violência presumida no caso da ocorrência de relação sexual entre um adulto e um menor de 14 anos (art. 224 do Código Penal Brasileiro). ${ }^{13}$

Essa obrigação, por constituir regra e não abranger nenhuma exceção deveria ser considerada como uma prescrição absoluta, ou seja, diante da validade da regra, ocorrendo a situação prevista, deveriam ser aplicadas suas consequências.

Porém na análise de um caso que se enquadrava na referida norma, a $2^{\mathrm{a}}$ Turma do STF decidiu pela não aplicação da regra ao caso concreto.

Ao julgar o habeas corpus, que envolvia uma menor de apenas 12 anos, o Tribunal considerou fatores como a aparência física e mental da vítima como pessoa mais velha, sua aquiescência, a situação atual da sociedade e a situação do paciente com vida e família constituída, decidindo assim pela não aplicação da regra prevista no Código Penal.

Como fundamentos para a decisão foi referida a colisão com o princípio da justiça e a contrariedade do caso concreto com a finalidade e

${ }^{13}$ STF - $2^{\mathrm{a}}$ Turma, HC 73.662-9, rel. Ministro Marco Aurélio, DJU 20.09.1996. 
os valores buscados pela regra. Os Ministros consideraram que a aplicação da regra ao caso constituiria uma enorme injustiça, embora estivessem configurados todos os pressupostos para sua aplicação.

A justificativa para a referida aplicação da ponderação às regras deve-se ao fato de que embora a regra trate de condutas determinadas elas estão ligadas a valores e finalidades que buscam realizar. Sendo assim, nos casos em que a aplicação das determinações da regra viole os valores e finalidades buscados por ela, deve-se utilizar o método ponderativo para determinar a sua não aplicação.

Mas, note-se, que a possibilidade de discutir a justiça e as finalidades da regra em cada momento de sua aplicação, visando possibilitar seu afastamento, gera insegurança jurídica, reduz a previsibilidade do ordenamento e permite arbitrariedades. Enquanto, por outro lado, sua observância fiel, mesmo gerando injustiças ocasionais fortelece a ordem jurídica e a estrutura do Estado de direito.

Sendo assim, nos encontramos diante de um conflito ainda mais complexo, pois de um lado temos uma pessoa sujeita à aplicação de uma regra manifestamente injusta e de outro a possibilidade de violação do ordenamento com a redução da segurança jurídica e da previsibilidade, que são veiculações também consideradas na estrutura das regras.

A observância das regras garante, além dos fins específicos determinados por elas, outras finalidades insitas ao ordenamento jurídico, como a segurança, a previsibilidade e a importância da atuação legislativa. Essas finalidades tornam de extrema complexidade a ponderação de regras no caso em análise.

\footnotetext{
"Isso torna o debate sobre a ponderação de regras consideravelmente mais complexo, já que não se trata apenas de uma disputa entre os efeitos pretendidos pela regra e pelos outros enunciados normativos aparentemente em colisão. Mais que isso, cuida-se de uma erupção da tensão permanente que perspassa o sistema jurídico entre a realização da justiça no caso concreto e o aperfeiçoamento institucional do Estado de direito."
}

\footnotetext{
${ }^{14}$ BARCELLOS, Ana Paula. Ponderação, racionalidade e atividade jurisdicional. Rio de Janeiro: Renovar, 2005. p. 209.
} 
A segunda possibilidade da ponderação de regras apresenta-se quando, diante de um conflito de regras, não se consiga, utilizando os métodos hermenêuticos para a resolução de antinomias, decidir por nenhuma delas.

Nesse caso, também nos deparamos com uma ruptura do sistema jurídico porque a antinomia terá uma forma que deixará para o aplicador a decisão acerca de qual regra deve ser obedecida e qual deve ser desrespeitada.

Revela-se assim a necessidade de utilização do sistema ponderativo, que possuirá características próprias:

"A rigor, sequer se trata aqui de uma ponderação jurídica ou normativa, mas sim de uma ponderação de valores ou bens de forma mais geral. Isso porque, para escolher que regra deve ser aplicada, será nescessário ascender na escala de abstracão e examinar os fins, as razões e os valores que, em última análise, justificam cada uma das duas regras em confronto. $" 15$

A ponderação nesses casos serve de orientação para a escolha de uma das regras em confronto não deixando de configurar uma quebra do sistema, mas permitindo, por outro lado, a aplicação de critérios baseados na racionalidade ao optar por uma das regras. Deve-se considerar que na realidade não se trata de uma ponderação de regras e sim das finalidades e valores que estão por trás de cada uma delas.

Sendo assim, percebemos que mesmo nos casos de uma possível ponderação, não se afigura com simplicidade a aplicação do método ponderativo no caso dos conflitos de regras, ressaltando-se assim a necessidade e utilidade de uma distinção forte entre princípios e regras.

\footnotetext{
"A segunda possibilidade, sustentada expressamente por alguns autores que professam a distinção débil, consiste em admitir que todas as normas, sejam elas regras ou princípios, estão sujeitas à ponderação. O problema dessa visão é que quando se trata de interpretar normas constitucionais, a idéia de que regras podem ser ponderadas compromete gravemente a força vinculante da Lei Maior. A adoção de uma distinção forte entre regras e princípios, ao revés, determina soluções diferenciadas para a interpretação das duas categorias de normas, estabelecendo, assim, um razoável equilíbrio entre vinculação e flexibilidade.
}

\footnotetext{
${ }^{15}$ BARCELLOS, Ana Paula. Ponderação, racionalidade e atividade jurisdicional. Rio de Janeiro: Renovar, 2005. p .212.
} 
Fica definido, a partir do aspecto estrutural da norma, um parâmetro de atuação para o intérprete." 16

\subsection{Outras distinções}

$\mathrm{Na}$ doutrina, são apontadas outras distinções na busca da diferenciação entre princípios e regras, que iremos abordar de forma resumida, por não representarem significativas contribuições para o tema em análise.

José Joaquim Gomes Canotilho apresenta quatro critérios além dos acima elencados que merecem ser considerados, são eles o do grau de determinabilidade, do caráter de fundamentabilidade, da proximidade da idéia de direito e da natureza normogenética.

O critério do grau de determinabilidade se verifica na aplicação dos casos concretos, pois os princípios por serem vagos, carecem de mediações concretizadoras do intérprete enquanto as regras são aplicadas de modo direto.

O caráter de fundamentabilidade sustenta que os princípios são normas de natureza estruturante ou com um papel fundamental no ordenamento jurídico devido à sua posição de hierarquia como fonte ou à sua importância estruturante no sistema jurídico.

A distinção da proximidade da idéia de direito coloca os princípios como standarts juridicamente vinculantes radicados nas exigências de justiça ou na idéia de direito, enquanto as normas podem ter características de normas vinculativas com conteúdo meramente formal.

Por fim, o critério da natureza normogenética coloca os princípios como base, fundamento da criação de regras, constituindo sua ratio. ${ }^{17}$

\footnotetext{
${ }^{16}$ PEREIRA, Jane Reis Gonçalves. Interpretação constitucional e direitos fundamentais: uma contribuição ao estudo das restrições aos direitos fundamentais na perspectiva da teoria dos princípios. Rio de Janeiro: Renovar, 2006. p.114

${ }^{17}$ CANOTILHO, J. J. Gomes. Direito Constitucional e Teoria da Constituição. $7^{\mathrm{a}}$ ed. Coimbra: Almedina, 2003. p. 1160 e 1161.
} 


\subsection{A Teoria dos Princípios e os Direitos Fundamentais}

Diante do demonstrado, podemos perceber que a aplicação e interpretação das normas constitucionais está diretamente ligada à classificação normativa em princípios e regras.

Dessa forma, no âmbito dos direitos fundamentais também assume grande importância a distinção ora apresentada. Isso porque, partindo desta distinção, poderemos definir as possibilidades de impor restrições a esses direitos e também os critérios de interpretação a serem utilizados em caso de conflitos.

A classificação normativa dos direitos fundamentais dividiu a doutrina em três correntes que pregam modelos diferentes de aplicação desses direitos. Em primeiro lugar há defensores do modelo no qual todos os direitos fundamentais são normas que assumem a natureza de regras. Em segundo lugar, e no extremo oposto, há os que sustentam que todos os direitos fundamentais são revestidos da natureza de princípios. Por fim, existe a corrente que, ao conciliar as duas noções, sustenta que os direitos fundamentais são de conteúdo misto, existindo entre eles regras e princípios.

Assim analisaremos as vantagens e desvantagens da adoção de cada um dos modelos acima referidos, buscando o melhor método para a aplicação e interpretação dos direitos fundamentais.

\subsubsection{Modelo puro de regras}

Esse modelo prega que todas as normas de direitos fundamentais possuem a estrutura de regras e é considerado por Robert Alexy como o modelo mais atraente do ponto de vista da vinculação ao texto constitucional, da segurança jurídica e da previsibiliade. ${ }^{18}$

\footnotetext{
${ }^{18}$ ALEXY, Robert. Teoria dos Direitos Fundamentais. Traduzido por Virgílio Afonso da Silva. São Paulo: Malheiros Editores, 2008. p.123. Apesar de sustentar ser o modelo mais atraente o
} 
Os defensores desse tipo de modelo sustentam que os direitos fundamentais, mesmo sendo normas carentes de complementação, são comandos absolutos e incondicionais, não podendo se sujeitar a métodos ponderativos e nem a qualquer modo de sopesamento. Nesse sentido, posicionam os direitos fundamentais como irrestringíveis e criticam o método ponderativo como constitucionalmente inadequado por causar insegurança.

$\mathrm{Na}$ defesa dessa linha de pensamento, sustentam que a solução dos casos deve se dar por meio de uma interpretação sistemática e propõem três modos de solucionar conflitos entre direitos fundamentais.

Em primeiro lugar surge a proposta de declarar um dos direitos como inválido sendo correspondente às teses que pregam a hierarquia constitucional dos direitos fundamentais. Essa forma de resolução de conflitos não pode ser aceita, posto que, conforme a rigidez constitucional as normas de mesmo plano hierárquico não podem ser consideradas inválidas. ${ }^{19}$

Como segunda alternativa é proposto o método de não aplicação de um dos direitos ao caso, ou seja, na análise do caso concreto busca-se o entendimento de que um dos direitos em conflito não se aplica àquela situação. Os que sustentam essa opção são contrários a utilização de qualquer método ponderativo, defendendo que sempre seria possível detalhar o âmbito de aplicação dos direitos fundamentais de forma a não possibilitar sobreposições. Sendo assim, os conflitos seriam resolvidos com base em uma lógica binária, na qual haveria uma análise de se os fatos estão dentro ou fora da esfera de proteção do direito fundamental em questão.

autor faz duras críticas demonstrando a impossibilidade de sua adoção e a preferência por um modelo misto de regras e princípios.

19 PEREIRA, Jane Reis Gonçalves. Interpretação constitucional e direitos fundamentais: uma contribuição ao estudo das restrições aos direitos fundamentais na perspectiva da teoria dos princípios. Rio de Janeiro: Renovar, 2006. p.123 
Esse método de resolução dos conflitos, mesmo parecendo bastante atrativo, mostra-se de difícil aplicação.

Nesse sentido manifestou-se a autora Jane Reis Pereira Gonçalves, determinando que a utilização dessa opção de resolução de conflitos revelaria "um otimismo infundado quanto à possibilidade de determinar de forma objetiva e absoluta, o conteúdo máximo dos direitos em cada caso" e que "as operações hermenêuticas tendentes a definir os direitos levam a concebê-los de forma excessivamente restritiva e não oferecem mais garantias de objetividade e racionalidade do que a ponderação. „20

Por fim, a última alternativa aos conflitos de direitos fundamentais, seria resolvê-los com a introdução de uma cláusula de exceção em um dos direitos, entendendo que a aplicação de uma das normas em conflito geraria uma ressalva na aplicação da outra. Esse método de solução traria grandes problemas por permitir a aplicação de uma pluralidade de exceções aos direitos fundamentais, tornando essas normas insuficientes para cumprir seus objetivos constitucionais.

Sendo assim, demostra-se a inconsistência do modelo puro de regras, permitindo considerar que a pura negação ao sopesamento como método de interpretação adequado já permite críticas e questionamentos acerca de sua aceitabilidade.

\subsubsection{Modelo puro de princípios}

Em sentido diametralmente oposto, encontra-se o modelo que determina que todos os direitos fundamentais são normas com a estrutura de princípios e poderiam em qualquer caso ser objeto de ponderação.

Os defensores desse modelo determinam que as regras só existiriam como resultados de ponderações, ou seja, as regras seriam apenas os

\footnotetext{
${ }^{20}$ PEREIRA, Jane Reis Gonçalves. Interpretação constitucional e direitos fundamentais: uma contribuição ao estudo das restrições aos direitos fundamentais na perspectiva da teoria dos princípios. Rio de Janeiro: Renovar, 2006. p.123
} 
resultados dos sopesamentos que determinariam a precedência de certo direito fundamental diante de um caso concreto.

A dificuldade de adoção desse modelo reside na negação da Constituição como uma construção rígida, permitindo assim uma flexibilidade excessiva na interpretação e aplicação dos direitos fundamentais. Por mais que seja permitido, em algumas situações especiais, o desvio do texto constitucional, não se deve adotar essa conduta como regra, sob pena de violação do caráter vinculante da Constituição.

Os direitos fundamentais possuem graus de densidade e abertura diferentes, não sendo razoável entender todos eles como comandos prima facie. $^{21}$

\subsubsection{Modelo misto de príncipios e regras}

Diante da demonstrada inaplicabilidade e inconsistência dos modelos acima, foi proposto um modelo misto, no qual existiriam no ordenamento jurídico direitos fundamentais com estrutura de regras e direitos fundamentais com a estrutura de princípios.

Esse modelo busca conciliar a rigidez excessiva do modelo puro de regras e a flexibilidade do modelo de princípios, sendo denominado de teoria dos princípios.

Alexy sustenta que nesse modelo teríamos o nível dos princípios e o nível das regras e considera a possibilidade de termos normas de caráter duplo, abrangendo características de princípios e de regras

"Uma tal vinculação de ambos os níveis surge quando na formulação de uma norma constitucional é incluída uma cláusula restritiva com a estrutura de princípios, que, por isso, está sujeita a sopesamentos.”22

\footnotetext{
${ }^{21}$ PEREIRA, Jane Reis Gonçalves. Interpretação constitucional e direitos fundamentais: uma contribuição ao estudo das restrições aos direitos fundamentais na perspectiva da teoria dos princípios. Rio de Janeiro: Renovar, 2006. p.124

${ }^{22}$ ALEXY, Robert. Teoria dos Direitos Fundamentais. Traduzido por Virgílio Afonso da Silva. São Paulo: Malheiros Editores, 2008. p. 141.
} 
$\mathrm{Na}$ adoção desse modelo Alexy preconiza que os princípios são subjacentes às regras mas por outro lado afirma que:

"As disposições de direitos fundamentais podem - e com isso se adentra o
segundo nível - ser consideradas não somente como uma positivação e uma
decisão a favor de princípios, mas também como a expressão de uma tentativa de
estabelecer determinações em face das exigências de princípios contrapostos.
Dessa forma, elas adquirem um caráter duplo. De um lado, princípios são
positivados por meio delas; mas, de outro lado, elas contêm determinações em
face das exigências de princípios contrapostos, na medida em que apresentam
suportes fáticos e cláusulas de restrição diferenciados. (...) Quando, por meio de
uma disposição de direito fundamental, é fixada alguma determinação em relação
às exigências de princípios colidentes, então, por meio dela não é estabelecido
somente um princípio mas também uma regra.".23

Sendo assim, diante dessas afirmações, percebemos que uma mesma disposição de direito fundamental pode ter a estrutura de regras e princípios, conciliando assim a flexibilidade com a taxatividade.

Esse modelo demonstra-se o mais adequado para a adoção pelas constituições. Nossa Constituição adotou esse modelo misto, tendo direitos fundamentais de densidade variada, seguindo a estrutura de regras e de princípios.

A análise dos dispositivos constitucionais nos leva à percepção desse sistema, podendo ter como exemplo a isonomia que é tratada de forma ampla no preâmbulo constitucional, estando melhor delineada no art. $5^{\circ}$, inciso I e tendo diversas concretizações do instituto espalhadas pela Constituição na definição de situações mais específicas.

Dessa forma, afigura-se indispensável uma classificação dos direitos fundamentais como regras ou como princípios para a adoção de modelos de solução de conflitos de direitos fundamentais. Nesse sentido, considerá-los como princípios nos leva à utilização do método ponderativo, enquanto considerá-los como regras, torna-os irrestringíveis e dependentes da utilização de um método binário para sua aplicação.

\footnotetext{
23 ALEXY, Robert. Teoria dos Direitos Fundamentais. Traduzido por Virgílio Afonso da Silva. São Paulo: Malheiros Editores, 2008. p. 139 e 140.
} 


\section{Capítulo II - Conflito de direitos fundamentais}

$\mathrm{Na}$ análise dos conflitos de direitos fundamentais, alguns princípios de interpretação constitucional irão assumir especial relevo. São eles o princípio da unidade da Constituição e o princípio da máxima efetividade das normas constitucionais.

O princípio da unidade da Constituição propugna pela interpretação das normas constitucionais como um todo harmônico, afastando-se eventuais antinomias. Nesse sentido, as referidas normas formam um sistema coordenado, determinando que no caso de normas colidentes a solução deve se basear em um esforço de otimização e harmonização das normas constitucionais.

Essa harmonização a ser realizada pelo intéprete, deve ocorrer de forma que nenhuma das normas perca sua eficácia, ou seja, a antinomia demonstra-se apenas aparente, devendo o intérprete buscar o equilíbrio entre as normas e garantir-lhes eficácia.

Nesse sentido Luis Roberto Barroso ensina que:

"O papel do princípio da unidade é o de reconhecer as contradições e tensões reais ou imaginárias - que existam entre normas constitucionais e determinar a força vinculante e o alcance de cada uma delas. Cabe-lhe, portanto, o papel da harmonização ou "otimização" das normas, na medida em que se tem de produzir um equilíbrio, sem jamais negar por completo a eficácia de qualquer delas." 24

A exigência do princípio da máxima efetividade das normas constitucionais determina que estas devem ser interpretadas e aplicadas de modo a obterem o maior nível possível de eficácia diante das circunstâncias de cada caso.

Disso resulta o entendimento de que as normas constitucionais têm eficácia jurídica e são imperativas, podendo seu cumprimento ser exigido de forma coativa. As normas de direitos fundamentais são também dotadas

\footnotetext{
${ }^{24}$ BARROSO, Luis Roberto. Interpretação e aplicação da constituição: fundamentos de uma dogmática constitucional transformadora. 6. ed. rev., atual. e ampl. São Paulo: Saraiva, 2004. p. 200.
} 
de força vinculante e sua pretensão de eficácia - produção de efeitos no mundo real - também pode ser exigida perante o Poder Judiciário. ${ }^{25}$

Somado a isso, encontramos uma ordem constitucional que consagra uma pluralidade de valores e idéias, tornando-se, assim, seio de normas potencialmente colidentes. Isso resulta de uma sociedade democrática e plural, consagrando opções políticas variadas e muitas vezes antagônicas. ${ }^{26}$

Sendo assim, na prática constitucional muitas vezes a determinação da norma a ser aplicada é árdua e complexa, pois os fatos apontam para mais de uma norma aplicável que indicam soluções conflitantes para o caso.

No âmbito dos direitos fundamentais esse tipo de conflito revela-se especialmente comum, por serem normas abertas e variáveis passíveis de gerar inúmeras tensões. Robert Alexy determina até que "não existe catálogo de direitos fundamentais sem colisão de direitos fundamentais e também um tal não pode existir." ${ }^{27}$ Devido a essas considerações, torna-se indiscutível que os direitos fundamentais não são absolutos ${ }^{28}$, pelo contrário, são dotados de certa relatividade.

\footnotetext{
${ }^{25}$ ALEXY, Robert ressalta que o problema da colisão desapareceria se as normas de direitos fundamentais fossem consideradas como não vinculativas e não caberiam assim nas discussões dos tribunais. Consigna ainda que no Brasil, devido ao art. $5^{\circ}, \S 1^{\circ}$, da Constituição Federal, não se pode declarar os direitos fundamentais como não vinculativos, pois o referido artigo considera os direitos como diretamente aplicáveis. Insurge-se ainda contra qualquer tipo de tentativa de declaração da não justiciabilidade dos direitos fundamentais ao afirmar que " a todas as tentativas de desagravar o problema da colisão pela eliminação da justiciabilidade deve opor-se com energia. Elas não são outra coisa senão a solução de problemas jurídicos- constitucionais pela abolição do direito constitucional". Esse entendimento encontra-se consagrado na doutrina pátria e é expresso pelo autor em seu artigo Colisão de direitos fundamentais e realização de direitos fundamentais no Estado de direito democrático, publicado na Revista de Direito Administrativo, Rio de Janeiro , n.217,p. 67-79, jul./set. 1999.

${ }^{26}$ PEREIRA, Jane Reis Gonçalves. Interpretação constitucional e direitos fundamentais: uma contribuição ao estudo das restrições aos direitos fundamentais na perspectiva da teoria dos princípios. Rio de Janeiro: Renovar, 2006. p. 222.

${ }^{27}$ ALEXY, Robert. Colisão de direitos fundamentais e realização de direitos fundamentais no Estado de direito democrático. Revista de Direito Administrativo, Rio de Janeiro , n.217,p. 67-79, jul./set. 1999. p. 68.

28 “A regra geral é de que todos os direitos fundamentais são limitáveis, não há direitos absolutos, no sentido de que todos os direitos, dependendo das circunstâncias concretas do caso e dos valores e bens dignos de proteção que se lhes oponham, podem ter que ceder." NOVAIS, Jorge Reis. Direitos Fundamentais: Trunfos Contra a Maioria. Coimbra, 2006. p. 49.
} 
Ressalte-se que os direitos fundamentais, na maioria das vezes, estabelecem princípios, colocando-nos diante de colisões principiológicas a serem solucionadas. ${ }^{29}$

Dessas considerações surgem diversos questionamentos: quais são os limites a serem considerados para que a relatividade dos direitos fundamentais não lhes retire a eficácia? Como respeitar os princípios da unidade da constituição e da máxima efetividade nos casos de tensão onde a realização de um direito fundamental implica a restrição de outro direito fundamental? Diante do conflito, qual norma deve ser aplicada? Quais os métodos aptos a conciliar e harmonizar as normas constitucionais nos casos de conflito de direitos fundamentais?

Essas e outras indagações são comuns no estudo dos direitos fundamentais em colisão. Porém, antes de começarmos a elaborar respostas, duas características relativas ao conflito de direitos fundamentais devem ser consideradas.

Primeiramente devemos indagar se os critérios tradicionais para a solução de antinomias - critério cronológico, hierárquico e da especialidade - são também suficientes para a resolução dos conflitos de direitos fundamentais.

Em resposta, considere-se que, como estamos tratando de normas constitucionais, estas são contemporâneas e de mesma hierarquia, eliminando assim a aplicação dos critérios tradicionais e exigindo critérios hermenêuticos mais abertos e flexíveis para se compatibilizarem aos conflitos de direitos fundamentais.

\footnotetext{
${ }^{29}$ O presente trabalho adota a posição da teoria dos princípios considerando que os direitos fundamentais podem ter a estrutura de regras e de princípios. Explicitando esse entendimento Jane Reis Gonçalves Pereira em seu trabalho Interpretação constitucional e direitos fundamentais: uma contribuição ao estudo das restrições aos direitos fundamentais na perspectiva da teoria dos princípios. Rio de Janeiro: Renovar, 2006. p. 223. nota de rodapé n ${ }^{\circ} 26$ cita Robert Alexy nos seguintes termos "A teoria dos princípios não diz que o catálogo dos direitos fundamentais não contém regras; isto é, que ela não contém definições precisas. Ela afirma não apenas que os direitos fundamentais, enquanto balizadores de definições precisas e definitivas, têm a estrutura de regras, como também acentua que o nível de regras precede prima facie o nível dos princípios. O seu ponto decisico é o de que atrás e ao lado das regras existem princípios."
} 
Jane Reis Gonçalves Pereira traz precisa lição ressaltando a não aplicabilidade dos critérios tradicionais:

“ Desses aspectos inerentes às colisões de direitos fundamentais deflui uma conclusão sempre lembrada em doutrina: os conflitos que os envolvem não podem, normalmente, ser resolvidos recorrendo aos critérios clássicos de resolução de antinomias. O critério hierárquico - lex superior derogat inferior não vale, à medida que se trata de normas que estão no mesmo plano hierárquico. Também não é operativo o critério temporal - lex posterior derogat priori - pois que se trata de direitos positivados ao mesmo tempo. Por fim, sendo os conflitos de direitos fundamentais do tipo parcial-parcial e em concreto, não há, de um modo geral, relação de especialidade entre eles, razão por que é ineficaz o critério lex specialis derogat generali. Não sendo apropriados tais critérios, impõe-se a utilização de outras técnicas hermenêuticas destinadas a determinar o direito aplicável nos casos de conflito." 30

Em segundo lugar, devemos considerar que as situações de tensão entre direitos fundamentais, em geral, só são identificadas em concreto, ou seja, as normas que abstratamente se mostram compatíveis, diante do caso concreto, assumem posições de superposição, demonstrando-se incompatíveis. ${ }^{31}$ Nesse sentido Daniel Sarmento leciona:

“(...) a resolução dos conflitos entre princípios constitucionais requer uma análise da situação concreta em que emergiu o conflito. $\mathrm{O}$ equacionamento das tensões principiológicas só pode ser empreendido à luz das variáveis fáticas do caso, as quais indicarão ao intérprete o peso específico que deve ser atribuído a cada cânone constitucional em confronto" ${ }^{32}$

Destacadas as considerações necessárias passemos à análise da tipologia dos conflitos de direitos fundamentais e dos métodos de resolução, com vistas a solucionar as indagações suscitadas.

\footnotetext{
${ }^{30}$ PEREIRA, Jane Reis Gonçalves. Interpretação constitucional e direitos fundamentais: uma contribuição ao estudo das restrições aos direitos fundamentais na perspectiva da teoria dos princípios. Rio de Janeiro: Renovar, 2006. p. 229.

31 Existem antinomias em abstrato e antinomias em concreto. As primeiras são facilmente identificadas pela mera leitura das normas que se demostram claramente incompatíveis; como exemplo teríamos uma antinomia em abstrato no caso de uma norma que determina "é proibido fumar nos restaurantes" e de outra que determina "é permitido fumar cigarro nos restaurantes". Sendo o cigarro um tipo de fumo percebemos facilmente a antinomia sem ser necessário o recurso ao caso concreto. Nas antinomias em concreto a oposição não existe a primeira vista, sendo as normas abstratamente compatíveis, porém, no caso concreto, verifica-se sua incompatibilidade. É o caso de uma norma que determine "é proibida a entrada de animais doentes na universidade" e outra que determine "é permitida a entrada de cães guias na universidade"; nesse caso existe compatibilidade entre as normas, apresentendo-se incompatíveis apenas no caso acidental de cães guias doentes pretenderem ser levados à universidade.

32 SARMENTO, Daniel. Os princípios constitucionais e a ponderação de bens. In : Teoria dos direitos fundamentais. Coor. TORRES, Ricardo Lobo. 2. ed. rev. e atual. Rio de Janeiro: Renovar, 2001.p.55.
} 


\subsection{Tipos de conflito de direitos fundamentais}

Visando determinar de forma precisa os contornos do tema, iremos inicialmente distinguir os possíveis tipos de conflitos de direitos fundamentais

As situações de conflito se desdobram em dois tipos básicos: a concorrência e a colisão de direitos fundamentais. Esse segundo tipo se subdivide em colisões em sentido amplo e colisões em sentido estrito; estas serão o principal objeto de nosso estudo em sua metódica de solução.

\subsubsection{Concorrência de direitos fundamentais}

A concorrência de direitos fundamentais ocorre quando uma conduta de um mesmo titular pode ser encaixada na proteção de diversos direitos fundamentais, ou seja, o comportamento preenche os "pressupostos de fato" de vários direitos. ${ }^{33}$

Esse fenômeno pode se manifestar de duas formas: o cruzamento e a acumulação de direitos fundamentais. Pela primeira forma, temos a situação em que o mesmo comportamento é encaixado no âmbito protetivo de vários direitos fundamentais. Pela segunda, vislumbramos os casos em que um determinado bem jurídico, de forma a propiciar sua proteção e concretização, exige a acumulação de vários direitos fundamentais em uma pessoa.

Para o ilustre professor J.J.Gomes Canotilho o problema forma-se quando os direitos cruzados ou acumulados estão sujeitos a limites divergentes, sendo necessário determinar qual deles assume um relevo decisivo. ${ }^{34}$

$\mathrm{Na}$ solução da problemática o autor apresenta dois topoi orientadores. Em primeiro lugar considera que deve prevalecer, em caso de

${ }^{33}$ CANOTILHO, J. J. Gomes. Direito Constitucional e Teoria da Constituição. $7^{\mathrm{a}}$ ed. Coimbra: Almedina, 2003. p. 1268.

${ }^{34}$ CANOTILHO, J. J. Gomes. Direito Constitucional e Teoria da Constituição. $7^{\mathrm{a}}$ ed. Coimbra: Almedina, 2003. p. 1269. 
existência, a norma constitucional especial, configurando-se assim uma concorrência inautêntica ou parcial. Em segundo lugar, no caso de inexistência de norma constitucional especial, devem prevalecer os direitos fundamentais menos limitados ou que reúnam em maior grau elementos estruturantes de um dos direitos. ${ }^{35}$

\subsubsection{Colisão de direitos fundamentais em sentido estrito}

Esse tipo de colisão de direitos fundamentais se configura pelo choque de direitos fundamentais individuais. Nessa situação, temos o exercício do direito fundamental de um indivíduo que impede ou prejudica o exercício do direito fundamental de outro indivíduo.

Nas palavras de R. Alexy esse tipo de colisão decorre sempre de situações "quando o exercício ou a realização do direito fundamental de um titular de direitos fundamentais tem consequências negativas sobre os direitos fundamentais de outros titulares de direitos fundamentais."

Os direitos colidentes podem ser idênticos ${ }^{37}$, como no caso da realização de um aborto terapêutico pelo fato de a gravidez gerar sérios

\footnotetext{
${ }^{35}$ Para uma explicação mais detalhada e exemplificada sobre o tema consulte-se: CANOTILHO, J. J. Gomes. Direito Constitucional e Teoria da Constituição. $7^{\mathrm{a}}$ ed. Coimbra: Almedina, 2003. p. 1268 a 1270 e MENDES, Gilmar Ferreira. Hermenêutica constitucional e direitos fundamentais. Brasília: Brasília Jurídica, 2002. p. 311 a 313.

${ }^{36}$ ALEXY, Robert. Colisão de direitos fundamentais e realização de direitos fundamentais no Estado de direito democrático. Revista de Direito Administrativo, Rio de Janeiro , n.217,p. 67-79, jul./set. 1999. p. 68.

${ }^{37}$ ALEXY, Robert define quatro tipos de colisão de direitos fundamentais idênticos em seu artigo Colisão de direitos fundamentais e realização de direitos fundamentais no Estado de direito democrático. Revista de Direito Administrativo, Rio de Janeiro, n.217,p. 67-79, jul./set. 1999. Seguindo essa classificação PEREIRA, Jane Reis Gonçalves sintetiza: "Os conflitos de direitos idênticos podem apresentar-se de quatro formas: i) colisão entre dois direitos fundamentais na dimensão liberal defensiva - que ocorre, por exemplo, quando dois grupos que defendem idéias antagônicas pretendem realizar uma manifestação no mesmo local; ii) colisão entre um direito fundamental em sua vertente defensiva, de uma parte, e na dimensão de proteção, de outra parte como, por exemplo, na hipótese de desferir-se tiros contra um sequestrador, para salvar a vida de um refém; iii) colisão da dimensão negativa de um direito, com a dimensão positiva desse mesmo direito - um exemplo desse tipo de colisão é a discussão sobre se o Estado pode ou não colocar crucifixos em salas de aula de escolas públicas; nesse caso, há um conflito entre o aspecto negativo da liberdade religiosa dos que não são critãos, com o direito dos adeptos do cristianismo a manifestar sua fé no âmbito das instituições estatais; e iv) colisão entre a dimensão formal e a material de um mesmo direito - que ocorre, especificamente, em relação ao princípio da igualdade. A implementação da igualdade em sentido material - tratamento desigual aos desiguais, visando a correção das desigualdades - implica, como regra, uma compressão da igualdade na dimensão formal, que corresponde ao tratamento legislativo idêntico a todas as pessoas, independentemente
} 
riscos para a vida da gestante; nesse caso vislumbramos o conflito do direito à vida da gestante e do direito à vida do nascituro. Podem também colidir direitos diferentes como na discussão da legalização do aborto, na qual colidem de um lado o direito à vida do nascituro e de outro o direito à autonomia da gestante.

\subsubsection{Colisão de direitos fundamentais em sentido amplo}

Esse tipo de colisão ocorre quando o exercício do direito fundamental de um indivíduo colide com bens constitucionalmente protegidos ou bens e valores de interesse público ou coletivo.

Exemplo clássico desse tipo de conflito é a oposição do direito de propriedade ao direito ao meio ambiente equilibrado e o dever de proteção do meio ambiente pelo Estado.

Nesse caso, devemos ressaltar que a ocorrência desse tipo de conflito não corresponde a uma oposição permanente entre bens coletivos e direitos individuais $^{38}$. Os bens coletivos servem diversas vezes como meios para a realização de direitos individuais, como no caso da obrigação de as indústrias de tabaco colocarem avisos informativos sobre os prejuízos que seus produtos causam à saúde; nesse caso, ao lado do bem coletivo de proteção à saúde da população, encontra-se também a busca de proteção da vida e da saúde do indivíduo.

de suas condições específicas". Interpretação constitucional e direitos fundamentais: uma contribuição ao estudo das restrições aos direitos fundamentais na perspectiva da teoria dos princípios. Rio de Janeiro: Renovar, 2006. p. 230 e 231.

38 "Bens coletivos não são só, naturalmente, adversários de direitos individuais. Eles também podem ser pressuposto ou meio de seu cumprimento ou fomento. " ALEXY, Robert. Colisão de direitos fundamentais e realização de direitos fundamentais no Estado de direito democrático. Revista de Direito Administrativo, Rio de Janeiro, n.217,p. 67-79, jul./set. 1999. p. 71. 


\subsection{Os hard cases e o método da subsunção}

O método da subsunção foi largamente utilizado como critério único da aplicação dos direitos, método esse baseado no silogismo no qual vamos ter uma premissa maior agindo sobre uma premissa menor e produzindo assim uma conclusão. No caso da aplicação no âmbito jurídico a premissa maior seria a fórmula normativa, que incidiria sobre o fato em exame (premissa menor) levando então a uma conclusão, que seria a aplicação da norma ao caso concreto, exprimida na sentença.

Esse método, ainda demostra sua importância no ordenamento perante a análise de casos rotineiros, que exigem uma simples aplicação de normas jurídicas levando muitas vezes a decisões mecânicas. Como exemplo, podemos citar a norma que proibe a entrada de animais no parque sob pena de multa; no caso de uma pessoa levar seu cão para um passeio no parque, é de fácil realização a subsunção do fato à norma aplicando-se assim uma multa ao dono do cão.

Porém esse método não se torna suficiente diante de situações de conflitos de direitos onde temos uma série de normas incidindo em um único fato, de forma a impossibilitar a total garantia de todas elas no caso concreto, isso porque as normas tutelam valores distintos que se contrapõem na situação de fato. Essa é a situação que ocorre na colisão de direitos fundamentais e nesse caso o método da subsunção teria que optar por uma das normas, excluindo totalmente a outra, o que não é possível diante do fato de que do ponto de vista jurídico, todas as normas constitucionais têm igual dignidade e importância, ou seja, não há hierarquia entre as normas constitucionais, não podendo o aplicador escolher uma norma em restrição da outra.

Esses são os considerados hard cases que são modelos típicos da colisão de direitos fundamentais, pois, por serem enunciados de igual hierarquia e força vinculante, como já demonstrado, exigem uma aplicação que privilegie os princípios da unidade da Constituição, da máxima 
efetividade dos direitos fundamentais e da concordância prática. Nesse sentido a subsunção se demostra insuficiente para a resolução, posto que, sua lógica tentará impor o isolamento de uma única premissa maior, o que não é possível diante de normas de direitos fundamentais.

Nesse sentido são buscadas soluções e métodos novos para a resolução das colisões de direitos fundamentais, dentre os quais, a ponderação se apresenta com grande força e aceitação doutrinária.

A autora Jane Reis Gonçalves Pereira apresenta posição em parte divergente, entendendo que a subsunção complementaria o raciocínio ponderativo, ao considerar que no fundo a premissa maior é constituida pela interpretação do juiz; sendo assim, determina que o juiz se utiliza do método subsuntivo ao determinar as premissas maiores e, posteriormente ao raciocínio ponderativo, ao aplicar a norma ao caso concreto. Assim ao tratar do método da subsunção considera que:

"A sua insuficiência decorre do fato de que ele nada diz sobre os critérios a serem empregados para identificar e dotar de sentido a premissa maior. Como se ressaltou antes, a norma jurídica é produto da interpretação, o que significa que, a rigor, é o juiz que formula a premissa maior. (...). Assim, diversamente do que advoga a doutrina tradicional, o conceito de ponderação não se opõe ao de subsunção, mas o complementa. $\mathrm{O}$ juiz, em qualquer caso - seja ele fácil ou difícil - inicia e finaliza o processo hermenêutico com uma operação do tipo subsuntivo. De fato, mesmo nas hipóteses em que cabe aplicar o juízo ponderativo, o intérprete, antes de ponderar, deverá identificar, mediante um raciocínio subsuntivo, quais são as normas prima facie aplicáveis à situação em análise. E uma vez feita a ponderação e determinada a norma que deverá prevalecer na solução do caso, o processo hermenêutico é concluido com a construção de uma regra de solução do conflito que é aplicada mediante a subsunção. Assim, a ponderação não configura uma alternativa excludente à subsunção, mas constitui uma etapa da interpretação destinada a identificar e formular a norma jurídica aplicável, mediante subsunção, ao caso concreto. O problema, portanto, consiste em saber qual iter interpretativo será empregado para deteminar a premissa maior do raciocínio jurídico.,39

Independentemente do raciocínio que se siga, considerando a subsunção como método oposto ou complementar, percebemos que o método subsuntivo não se demonstra adequado por si só para determinar a solução dos hard cases, sendo necessário adoção de novos métodos de

${ }^{39}$ PEREIRA, Jane Reis Gonçalves. Interpretação constitucional e direitos fundamentais: uma contribuição ao estudo das restrições aos direitos fundamentais na perspectiva da teoria dos princípios. Rio de Janeiro: Renovar, 2006. p. 217 e 218. 
solução ou de novos métodos para a determinação da premissa maior, como se quiser considerar.

\subsection{A colisão de direitos fundamentais e a atuação dos três poderes}

Antes de analisarmos os possíveis métodos de resolução das colisões de direitos fundamentais, devemos ainda considerar a quem compete a criação das regras de solução, refletindo assim uma análise sobre a tarefa dos três poderes em matéria de colisão. ${ }^{40}$

O Poder Legislativo pode atuar na solução de colisões de direitos fundamentais, criando normas em abstrato, para serem aplicadas em situações em concreto, ou seja, o legislador pode prever possíveis hipóteses de conflito em concreto dos direitos fundamentais e assim fixar desde logo a solução adequada. "Além disso, é também tarefa do legislador ordinário concretizar direitos fundamentais e harmonizar direitos que eventualmente entrem em colisão." ${ }^{41}$ Nosso ordenamento jurídico apresenta diversas hipóteses de solução de conflitos pelo legislador, como exemplo, podemos citar a lei 9296/96 que prevê as hipóteses nas quais para fins de investigação criminal ou de instrução do processo penal é autorizada a interceptação telefônica, resolvendo assim, desde logo, possíveis situações de conflito entre a necessidade dessa interceptação e o direito fundamental à inviolabilidade das comunicações telefônicas previsto no art. $5^{\circ}$, inciso XII, da Carta Magna. Outro exemplo pode ser vislumbrado nos casos em que a ilicitude do aborto é excluída, evitando assim, eventuais confrontos entre direitos fundamentais da mãe e do nascituro.

Ao Poder Executivo não cabe qualquer ato que determine sua participação na disposição sobre direitos fundamentais. Por mais que essa determinação não seja explícita em nossa Constituição, pode ser construída

\footnotetext{
40 STEINMETZ, Wilson Antonio. Colisão de direitos fundamentais e principio da proporcionalidade. Porto Alegre: Livr. do Advogado, 2001. p. 69.

41 STEINMETZ, Wilson Antonio. Colisão de direitos fundamentais e principio da proporcionalidade. Porto Alegre: Livr. do Advogado, 2001. p. 70.
} 
por meio de uma interpretação sistemática do art.68, $\S 1^{\circ}$, II, que determina que não podem ser objeto de delegação os direitos de nacionalidade, cidadania, direitos individuais, políticos e eleitorais. É certo também que as medidas provisórias não podem dispor desses direitos. Sendo assim, conclui-se que o Executivo não pode dispor de direitos fundamentais por meio de atividade normativa primária e muito menos por meio de atividade normativa secundária, estando excluído da participação na criação de normas de solução para colisões de direitos fundamentais. ${ }^{42}$

Essa conclusão também pode ser retirada do texto do ilustre professor J.J.Gomes Canotilho ao determinar que o juízo de ponderação e a relação de prevalência podem ser realizados em nível legislativo e em nível judicial $^{43}$, não citando o Poder Executivo; por uma leitura dedutiva percebemos que também ele propugna por sua exclusão.

Por fim, é sabido que o Poder Judiciário exerce o papel mais relevante na solução das colisões de direitos fundamentais e isso se dá por três razões primordiais. Primeiro: porque os direitos fundamentais, como visto, são dotados de justiciabilidade e como cabe ao Poder Judiciário o pronunciamento de qualquer questão, pelo princípio da inafastabilidade do controle jurisdicional, os direitos fundamentais podem e devem ir a seara judicial buscar sua proteção. Segundo: porque o conflito sempre se dá em concreto, sendo as normas abstratamente compatíveis. E terceiro porque por mais que o legislador possa prever soluções em abstrato essas jamais serão completas, podendo sofrer distorções e ter fatos relevantes que não foram considerados. Sendo assim, percebe-se que a via judicial é a mais comum para a solução das colisões de direitos fundamentais.

Passaremos agora a analisar os métodos utilizados pelo intérprete na criação de soluções para esses conflitos.

42 STEINMETZ, Wilson Antonio. Colisão de direitos fundamentais e principio da proporcionalidade. Porto Alegre: Livr. do Advogado, 2001. p. 72 e 73. O Autor cita como exemplo a doutrina e jurisprudência espanholas que determinam de forma explícita o afastamento do Poder Executivo de qualquer atividade interventiva nos direitos fundamnetais.

${ }^{43}$ CANOTILHO, J. J. Gomes. Direito Constitucional e Teoria da Constituição. $7^{\mathrm{a}}$ ed. Coimbra: Almedina, 2003. p. 1141. 


\subsection{Métodos de resolução das colisões de direitos fundamentais}

Alguns são os métodos propostos para a resolução das colisões de direitos fundamentais; dentre eles, trataremos da hierarquização, da categorização, dos limites imanentes e da ponderação.

Devemos considerar que a criação de diferentes métodos se baseia em duas correntes básicas: as que negam os conflitos de direitos fundamentais de forma total ou parcial e assim negam também a utilização da técnica ponderativa; e as que reconhecem os conflitos, mas oferecem técnicas alternativas à ponderação. ${ }^{44}$

Outros fatores também se mostram relevantes na escolha dos métodos hermenêuticos para a resolução das colisões, dentre eles o conceito de interpretação judicial adotado, a noção sobre a função do Poder Judiciário na separação de poderes e a concepção dos direitos fundamentais como princípios ou como regras ${ }^{45}$.

\subsubsection{Hierarquização}

O método da hierarquização aceita a existência de colisões de direitos fundamentais, porém propugna por uma solução diferente da ponderação de direitos.

Seu desenvolvimento consiste na imposição de um escalonamento dos direitos fundamentais, de forma a determinar abstratamente sua importância e peso e formar uma escala rígida dos direitos constitucionais.

Sendo assim, com a existência de uma hierarquia, tornar-se-ia extremamente fácil a resolução das colisões de direitos fundamentais, bastando para tanto, analisar qual dos direitos em conflito encontra-se em

\footnotetext{
${ }^{44}$ BARCELLOS, Ana Paula. Ponderação, racionalidade e atividade jurisdicional. Rio de Janeiro: Renovar, 2005. p.57.

${ }^{45}$ Como visto, a consideração dos direitos fundamentais como regras leva a adoção de um método binário de aplicação enquanto considerá-los como princípios leva à solução das colisões com base em um método ponderativo. O presente trabalho adota a teoria dos princípios considerando a existência de colisões de direitos fundamentais.
} 
nível superior e determinar sua prevalência. Desta forma, os direitos mais bem situados na escala irão preponderar sobre os menos graduados. ${ }^{46}$

Boa parte da doutrina, ao propugnar por esse método, nega a utilização da ponderação, afirmando que esta está afeta a subjetivismos e que existe uma hierarquia entre os direitos a ser considerada. Sendo assim, a atividade do intérprete na resolução dos conflitos ficaria simplificada e seria objetiva, bastando uma análise da escala pré determinada dos direitos fundamentais.

Todavia esse método apresenta diversos problemas em sua adoção, primeiramente, viola de forma clara o princípio da unidade da constituição que determina que suas normas possuem igual valor e dignidade e devem conviver de forma harmônica. Em segundo lugar, propõe um tipo de solução que leva à total e necessária eliminação de um dos direitos envolvidos, violando assim a necessidade de harmonização dos direitos em conflito de forma a assegurar, quando possível, sua aplicação conjunta, não ignorando nenhum dos direitos e levando a uma preservação da Constituição. Em terceiro lugar, questiona-se a facilidade do método e a afirmação de não estar sujeito a subjetivismos. Isso porque pairam dúvidas sobre como estabelecer uma hierarquia abstrata dos direitos fundamentais, e também, sobre quem estaria apto a estabelecer essa escala de direitos. $\mathrm{Na}$ criação de uma escala também seriam utilizadas noções ponderativas para atribuir importância aos direitos e isso levaria a possibilidades de subjetivismos e discricionariedade, tão criticados na ponderação de interesses. Por fim, o método demonstra-se inapto a solucionar questões que envolvam colisões de direitos fundamentais idênticos.

Ressalte-se que no âmbito de Constituições rígidas não seria possível estabelecer hierarquias entre os direitos. Se isso se afigurasse possível, a própria Constituição estabeleceria a hirarquia ou, ao menos, critérios para formá-la. A não determinação constitucional pode ser interpretada,

\footnotetext{
${ }^{46}$ BARCELLOS, Ana Paula. Ponderação, racionalidade e atividade jurisdicional. Rio de Janeiro: Renovar, 2005. p.66.
} 
justamente, como o desejo do legislador constitucional de possibilitar uma flexibilidade na interpretação dos direitos fundamentais, não sendo desejável a cristalização e imposição de critérios morais, que estariam subjacentes a formação de escalas.

Refutado o método como incompatível com a ordem constitucional resta consignar que surge na doutrina outra vertente da hierarquização ${ }^{47}$ que propõe um método compatível com a ponderação de direitos. Essa vertente propugna pelo estabelecimento de certas hierarquias abstratas que poderiam ser afastadas diante do caso concreto, desde que justificadamente.

Como exemplo, poderíamos citar o princípio in dubio pro libertate que estabelece uma espécie de primazia ao direito de liberdade. Nesse sentido, em caso de colisões deve haver uma presunção a favor da liberdade e uma eventual restrição a esse direito exigirá uma justificação mais intensa que na restrição a outros direitos.

Outro exemplo é a determinação de prevalências aos direitos que visam fortalecer a noção de proteção à dignidade humana, por ser este o fundamento sobre o qual assenta toda a ordem constitucional brasileira. ${ }^{48}$

\footnotetext{
47 PEREIRA, Jane Reis Gonçalves aponta a existência de quatro vertentes do método hierarquizante: i) uma visão mais radical permitiria uma hierarquia entre as normas da Constituição e do direito suprapositivo, com a prevalência deste último; ii) uma segunda vertente admitiria a possibilidade de hierarquia material entre as normas integrantes da Constituição sendo possível invalidar normas oriundas do poder constituinte originário por desconformidade com outras normas de mesma origem, mas de maior importância; iii) um outro modelo, não concebe que normas oriundas do poder constituinte originário sejam invalidadas, mas admite o estabelecimento de uma ordem de preferência abstrata entre os direitos fundamentais, que deve ser utilizada como critério de resolução dos conflitos; iv) a última modalidade seria a empregada como critério adjacente à ponderação, na qual haveria um escalonamento abstrato que poderia ser afastado diante de casos concretos, mediante justificação. Para maiores considerações sobre o tema: PEREIRA, Jane Reis Gonçalves. Interpretação constitucional e direitos fundamentais: uma contribuição ao estudo das restrições aos direitos fundamentais na perspectiva da teoria dos princípios. Rio de Janeiro: Renovar, 2006. p. 243 a 252.

${ }^{48}$ BARCELOS, Ana Paula defende a utilização desse raciocínio como um standart a guiar o intérprete em casos de colisão de direitos. Ponderação, racionalidade e atividade jurisdicional. Rio de Janeiro: Renovar, 2005. p.72 a 74. Essa também é a visão de SARMENTO, Daniel em $A$ ponderação de interesses na Constituição Federal. Rio de Janeiro: Lúmen Júris, 2003. p. 118.
} 


\subsubsection{Categorização}

Esse método apresenta-se como mais uma forma de solucionar as possíveis colisões de direitos fundamentais e consiste em relacionar as categorias constitucionais aos fatos em análise.

Nesse sentido, o método propugna pela utilização de um raciocínio lógico dedutivo para delinear o campo de aplicação dos direitos e, a partir da definição de categorias, determinar o enquadramento das questões fáticas.

Diferentemente da ponderação, que realiza um sopesamento dos bens em conflito, a categorização irá apenas encaixar os fatos nas categorias de direitos fundamentais, ou seja, é realizada uma análise para determinar se os fatos controversos se encaixam nas proteções constitucionais.

Nessa análise os direitos devem ser vistos de forma integrada, consubstanciando suas finalidades e origens históricas e sociais. Uma vez delineadas as definições e aplicações de cada direito não haverá mais conflitos sendo necessário apenas determinar a que categoria pertencem os fatos.

Esse método, diante do caráter principiológico dos direitos fundamentais, não se demonstra apto a resolver todos os conflitos, principalmente os determinados como hard cases. Isso porque o método se relaciona com o raciocínio típico da subsunção e da aplicação binária das regras jurídicas, determinando se sob determinado fato incidem ou não as normas de direitos fundamentais.

Os defensores da categorização muitas vezes o adotam como excludente da ponderação e afirmam que o método não apresenta os vícios da técnica ponderativa, quais sejam: ilegitimidade democrática e ausência de parâmetros racionais de justificação.

Quanto à primeira crítica o método categorizador mostra-se realmente apto a solucionar o problema. Isso porque a idéia de que a ponderação ao realizar sopesamentos desconsidera o texto constitucional, 
violando o jogo democrático e a separação de poderes resta superada. A adoção do método leva apenas a uma interpretação da Constituição e a uma definição do conteúdo de suas normas como pertinente ou não aos fatos em análise evitando, assim, a idéia de conferir valores flexíveis aos direitos fundamentais.

Contudo, a segunda crítica não se mostra superada pelo método. A categorização dos fatos, com a interpretação e verificação da adequação da norma, não se mostra suficiente para conferir à decisão mais racionalidade que o método ponderativo. Explica-se: o raciocínio utilizado não esclarece como seria capaz de afastar a discricionariedade e o subjetivismo do método. Ao determinar o conteúdo das categorias de direitos fundamentais, os intérpretes podem continuar se valendo de critérios subjetivos não havendo qualquer garantia de maior segurança e objetividade. Ressalte-se também que a própria determinação do conteúdo das categorias de direitos fundamentais poderá se basear em um raciocínio bastante similar ao ponderativo, mas que não aponta uma concreta motivação do raciocínio utilizado. Essa crítica é reforçada por Jane Reis Gonçalves Pereira:

\begin{abstract}
"O que ocorre é que mesmo os métodos alternativos à ponderação, dentre os quais assume destaque a categorização, podem também envolver juízos morais e comportar acentuada dose de subjetivismo. Deveras, não são raraos os casos em que o esforço de subsunção dos fatos às categorias que defluem dos conteúdos constitucionais escamoteia uma verdadeira ponderação de interesses pautada por juízos morais, que, todavia, não é explicitada nas razões da decisão. Além disso, em muitas hipóteses, as definições e o enquadramento taxonômico das situações de fato promovidos pelos Tribunais são orientados por critérios ou dicotomias visivelmente arbitrárias." 49
\end{abstract}

Para ilustrar a afirmação, a autora traz como exemplo o caso da análise dos métodos agressivos no interrogatório de terroristas como métodos de tortura. Nesses casos, aponta a autora, a Corte Alta de Justiça de Israel e a Corte Européia de Direitos Humanos adotaram um conceito restrito de tortura, permitindo a adoção de atos visivelmente abusivos e

\footnotetext{
49 PEREIRA, Jane Reis Gonçalves. Interpretação constitucional e direitos fundamentais: uma contribuição ao estudo das restrições aos direitos fundamentais na perspectiva da teoria dos princípios. Rio de Janeiro: Renovar, 2006. p. 274.
} 
agressivos que provavelmente seriam reprovados se os acusados não estivessem sendo acusados de terrorismo. Dessa forma, a adoção de certas categorias para enquadrar os fatos como tortura foram guiadas por juízos morais, demonstrando que o método pode levar a decisões arbitrárias e incoerentes. $^{50}$

É certo que tanto a ponderação quanto a categorização envolvem um juízo criativo do julgador, mas a ponderação deve ser balizada por uma argumentação racional e encontra diversos limites em sua atuação, que serão apresentados mais à frente.

Por fim, insta observar que o método da categorização pode se mostrar relevante se combinado com o método ponderativo, constituindo este a primeira fase de análise da ponderação, sendo de grande importância a definição de categorias dos direitos como critério auxiliar e decorrente do método ponderativo. ${ }^{51}$

\subsubsection{Limites Imanentes}

A teoria dos limites imanentes se aproxima do método da categorização ao sustentar que os conflitos de direitos fundamentais podem ser solucionados pela mera interpretação das normas constitucionais.

A idéia dos limites imanentes foi concebida a partir da análise dos sistemas constitucionais de direitos fundamentais, nos quais o legislador é autorizado a regulamentar e definir os contornos de alguns direitos,

\footnotetext{
${ }^{50}$ Para mais informações sobre o caso: PEREIRA, Jane Reis Gonçalves. Interpretação constitucional e direitos fundamentais: uma contribuição ao estudo das restrições aos direitos fundamentais na perspectiva da teoria dos princípios. Rio de Janeiro: Renovar, 2006. p. 276 a 279.

51 "É importante ressaltar que não há incompatibilidade intrínseca entre a categorização e a ponderação. O raciocínio categorial é elemento indispensável à atividade interpretativa. Como se sabe, dotar de sentido as categorias normativas e verificar sua correspondência com os fatos é tarefa essencial ao processo hermenêutico em qualquer conjuntura. A interpreteção inicia-se sempre com uma leitura textual, a partir da qual se busca relacionar o significado dos preceitos normativos com o conjunto de eventos em análise. Dessa forma, pode-se dizer que a categorização, como regra, corresponde ao primeiro estágio do raciocínio judicial." PEREIRA, Jane Reis Gonçalves. Interpretação constitucional e direitos fundamentais: uma contribuição ao estudo das restrições aos direitos fundamentais na perspectiva da teoria dos princípios. Rio de Janeiro: Renovar, 2006. p. 236.
} 
enquanto outros direitos não comportam essa disposição. Sendo assim, por meio de uma interpretação lógica, considera-se que a Constituição vedou a restrição desses direitos. ${ }^{52 / 53}$

Porém, esse raciocínio lógico gerava diversos problemas pela relatividade dos direitos fundamentais, que na convivência com outros direitos gera situações de colisão, que precisam ser contornadas com restrições aos direitos fundamentais envolvidos.

Desta forma, questionou-se como contornar o problema diante de normas que vedavam a restrição a esses direitos. Como solução surge a idéia dos limites imanentes, dispondo que cada direito traz em si limites próprios, imanentes à sua estrutura e natureza.

Esses limites já estariam contidos na própria Constituição e formariam assim, o âmbito de abrangência do direito. Sendo assim, a regra que veda as restrições não seria atingida, pois os limites já estariam prédeterminados no próprio direito, não sofrendo restrições externas.

Os defensores dos limites imanentes pregam que nem todas as situações possíveis, incluídas no âmbito de um direito, estão por ele protegidas, pois há situações tais que, pela lógica constitucional, não podem ter pretensão de proteção com base em um direito fundamental. Isso se dá pelo fato de que a Constituição jamais protegeria determinadas situações no âmbito de um direito.

J. C. Vieira de Andrade traz excelentes exemplos para elucidar a questão:

"Por exemplo, terá sentido invocar a liberdade religiosa para efectuar sacrifícios humanos ou, associada ao direito de contrair casamento, para justificar a poligamia ou a poliandria? Ou invocar a liberdade artística para legitimar a morte de um actor no palco, para pintar no meio da rua, ou para furtar o material necessário à execução de uma obra de arte? Ou apelar ao direito de propriedade para não pagar impostos ou ao direito de educar os filhos para os espancar violentamente? Ou invocar a liberdade de reunião para utilizar um edifício

\footnotetext{
${ }^{52}$ BARCELLOS, Ana Paula. Ponderação, racionalidade e atividade jurisdicional. Rio de Janeiro: Renovar, 2005. p.58.

${ }^{53}$ A Constituição Portuguesa traz dispositivo explícito que determina que as restrições aos direitos fundamentais só podem ser aquelas autorizadas constitucionalmente. Essa é a redação do seu artigo $18, \mathrm{n}^{\circ} 2$ "A lei só pode restringir os direitos, liberdades e garantias nos casos expressamente previstos na Constituição, devendo as restrições limitar-se ao necessário para salvaguardar outros direitos ou interesses constitucionalmente protegidos."
} 
privado sem autorização, ou a liberdade de circulação para atravessar a via pública sem vestuário, ou o direito à greve para destruir ou danificar equipamentos da empresa ou para que o Governo faça pressão para o reconhecimento do estatuto de preso político aos membros de um grupo terrorista? Ou invocar o direito de manifestação para encerrar uma escola? $\mathrm{Ou}$ invocar o direito ao casamento para contrair matrimónio com uma pessoa do mesmo sexo? Ou invocar a liberdade de expressão para injuriar uma pessoa?

Nestes, como em muitos outros casos, não estamos propriamente numa situação de conflito entre o direito invocado e outros direitos ou valores, por vezes expressos através de deveres fundamentais: é o próprio preceito constitucional que não protege essas formas de exercício do direito fundamental, é a própria Constituição que, ao enunciar os direitos, exclui do respectivo programa normativo a proteç̧ão a esse tipo de situação.

E a diferença é importante, como veremos melhor, já que, a entender-se que não há conflito, a solução do problema não tem que levar em conta o direito invocado, porque ele não existe naquela situação." ${ }^{54}$

O problema do método apresentado consiste na não especificação de uma forma de determinação dos limites imanentes. Sendo assim, no caso de não concordância dos limites ${ }^{55}$ determinados, o intérpete não escaparia de um raciocínio envolto por ponderações e sujeito a imensos subjetivismos e arbítrio, porque, por mais que o intérprete se utilize de raciocínios ponderativos na demarcação dos limites, a idéia de esses limites serem imanentes e pré-existentes exclui a exigência de uma motivação racional.

Essa teoria é defendida com duas formas de aplicação. Para alguns doutrinadores todos os conflitos inexistiriam, sendo necessário apenas delimitar os limites dos direitos fundamentais, ou seja, bastaria analisar o âmbito de proteção da norma constitucional para determinar se o direito estaria ou não protegido. Sendo assim, com a identificação dos limites, o âmbito de proteção dos direitos seria menor que o esperado, não existindo

\footnotetext{
${ }^{54}$ ANDRADE, J. C. Vieira. Direitos Fundamentais na Constituição Portuguesa de 1976. $3^{\mathrm{a}}$ ed.. Coimbra: Almedina, 2004.p. 294 e 295.

55 Várias são as doutrinas adotadas para a definição dos limites imanentes. Para maiores informações consulte-se ANDRADE, J. C. Vieira. Direitos Fundamentais na Constituição Portuguesa de 1976. $3^{\text {a }}$ ed.. Coimbra: Almedina, 2004.p. 292 a 298; MENDES, Gilmar Ferreira. Hermenêutica constitucional e direitos fundamentais. Brasília: Brasília Jurídica, 2002. p.187 a 191; e PEREIRA, Jane Reis Gonçalves. Interpretação constitucional e direitos fundamentais: uma contribuição ao estudo das restrições aos direitos fundamentais na perspectiva da teoria dos princípios. Rio de Janeiro: Renovar, 2006. p.182 a 193.
} 
nenhum conflito. Ao intérprete caberia apenas a declaração desses limites, não sendo necessário recorrer à técnica da ponderação.

Diversamente, para outros doutrinadores, a teoria dos limites imanentes resolveria boa parte de situações que revelariam falsos conflitos por não estarem abrangidas no âmbito de proteção dos direitos fundamentais. Porém, em certas situações, mesmo com a consideração dos limites imanentes, os conflitos persistiriam sendo necessário o recurso à ponderação como único método apto a solucioná-los. Nesse entendimento a ponderação não é descartada, mas restam para sua aplicação um número reduzido de situações composto apenas por aquelas que não foram suficientemente solucionadas pela aplicação dos limites imanentes.

\subsubsection{Ponderação}

O método da ponderação ganhou força nos anos 50 como método de resolução de colisões de direitos fundamentais, principalmente nos ordenamentos americano e germânico.

O tema, a essa época, passou a ser largamente debatido, enfrentando diversas críticas. Todavia a ponderação adquiriu grande relevância em diversos ordenamentos jurídicos da atualidade.

Devemos considerar que o recurso à ponderação não é determinado nem vedado pelo texto constitucional. Sendo assim, devemos realizar a análise do método e das críticas levantadas contra ele para considerarmos o porquê de sua importância e se realmente ele se apresenta como a escolha mais interessante e segura para o ordenamento jurídico e o aplicador do direito.

\subsubsection{Conceito de ponderação}

A ponderação, na visão aqui adotada, é um método capaz de solucionar as colisões de direitos fundamentais com base em um sopesamento dos bens e interesses protegidos constitucionalmente. Ou seja, 
quando os direitos, no caso concreto, se mostram inconciliáveis, o método irá atribuir pesos aos direitos colidentes para assim justificar a decisão do caso.

No caso dos direitos conflitantes, deve-se levar em conta o peso de cada um deles, pois estes possuem uma dimensão de peso ou importância dentro do ordenamento jurídico que permite um escalonamento perante o caso concreto. Isso significa que esse método se realiza no caso concreto, ou seja, não existe uma prevalência absoluta de certos direitos sobre os outros, não existem direitos que por sua natureza vão sempre prevalecer, mas no caso concreto vão ser analisadas as pretensões com base nos argumentos divergentes, e por meio de uma ponderação vai se estabelecer a dimensão de peso e importância dos direitos colidentes. Nesse sentido, a ponderação irá determinar, diante da situação de fato na qual se formou o conflito, a medida em que os direitos irão ceder, ou quando forem completamente inconciliáveis, qual dos direitos deve preponderar temporariamente.

Todavia, o conceito de ponderação merece uma análise mais aprofundada pois, a doutrina e a jurisprudência têm adotado a expressão para identificar outros conceitos diferentes do exposto e que apresentam uma noção aberta da ponderação, traduzindo outras modalidades de raciocínio jurídico. Devido a isto, torna-se necessário apresentar esses outros conceitos de forma a separar o método ponderativo como contrapeso de bens de outras formas de raciocínio jurídico concebidas sobre a mesma nomenclatura.

Por vezes, a ponderação é considerada como um método para a determinação de conceitos indeterminados ${ }^{56}$ presentes nas regras e também como um processo de determinação de exceções jurídicas ${ }^{57}$.

\footnotetext{
${ }^{56}$ ÁVILA, Humberto adota essa posição ao asseverar que "a atividade de ponderação de regras verifica-se na delimitação de hipóteses normativas semanticamente abertas ou de conceitos jurídico-políticos, como Estado de Direito, certeza do Direito, democracia. Nesses casos o intérprete terá de examinar várias razões contra e a favor da incidência da regra, ou investigar um plexo de razões para decidir quais elementos constituem os conceitos jurídicos-políticos”. Teoria dos princípios: da definição à aplicação dos princípios jurídicos. 4. ed. rev. São Paulo: Malheiros, 2004. p.48. BARCELLOS, Ana Paula também segue essa linha ao afirmar que "É verdade que,
} 
É também dotada de um sentido que admite a solução de qualquer tipo de antinomia, ou seja, seria um método capaz de solucionar qualquer tipo de conflito normativo. Essa idéia de ponderação deve ser refutada, pois, como visto, os métodos hermenêuticos tradicionais são suficientes para solucionar diversas antinomias que surgem em nosso ordenamento. Sendo assim, o método ponderativo, pelas dificuldades em sua correta aplicação, deve ser reservado aos casos que não são solucionados pelos métodos tradicionais, já qualificados como hard cases. ${ }^{58}$

Esse conceito gera uma grande abertura do método da ponderação e é por meio dele que se fundamenta também a aplicação da ponderação de regras $^{59}$, raciocínio este, que já foi considerado como não adequado. ${ }^{60}$

Por fim, considera-se a ponderação como método de avaliação de razões, contra-razões e argumentos relevantes. Nesse sentido, percebemos uma confusão da ponderação com a interpretação. ${ }^{61}$ Aqui, de certa forma, encaixam-se os dois conceitos primeiramente apresentados, porque a definição de conceitos indeterminados e de exceções, no fundo, liga-se a

por vezes, a própria estrutura da regra admite certa ponderação interna para a definição de seu próprio sentido. O exemplo mais evidente dessa situação é dado pelas regras que contém conceitos jurídicos indeterminados ou cláusulas de indeterminação de outra natureza - como "mulher honesta", "relevante interesse social", dentre outros. Nessas hipóteses muitas vezes é possível superar o conflito externo da regra com outras normas dependendo do sentido que se atribua ao conceito jurídico indeterminado nela contido". Alguns Parâmetros Normativos para a Ponderação Constitucional. In: A nova interpretação constitucional: ponderação, direitos fundamentais $e$ relações privadas. Org. BARROSO, Luis Roberto. Rio de Janeiro: Renovar, 2006.p. 91.

57 Essa também é a posição adotada por ÁVILA, Humberto ao considerar que "o processo mediante o qual as exceções são constituidas também é um processo de valoração de razões: em função da existência de uma razão contrária que supera axiologicamente a razão que fundamenta a própria regra, decide-se criar uma exceção. Trata-se do mesmo processo de valoração de argumentos e contra-argumentos - isto é, de ponderação." Teoria dos princípios: da definição à aplicação dos princípios jurídicos. 4. ed. rev. São Paulo: Malheiros, 2004. p.46.

${ }^{58}$ BARCELLOS, Ana Paula. Ponderação, racionalidade e atividade jurisdicional. Rio de Janeiro: Renovar, 2005. p. 28 a 35.

59 Como dito, ÁVILA, Humberto, é adepto da ponderação de regras e considera que "A ponderação diz respeito tanto aos princípios quanto às regras". Teoria dos princípios: da definição à aplicação dos princípios jurídicos. 4. ed. rev. São Paulo: Malheiros, 2004. p.50.

${ }^{60}$ BARCELLOS, Ana Paula traz ainda uma outra conceituação de ponderação ao afirmar que "a ponderação é descrita por muitos autores como a forma de aplicação dos princípios". Assim, a autora refuta essa conceituação como não totalmente adequada por considerar que mesmo excepcionalmente a ponderação possa envolver regras e que há princípios que não funcionam completa ou necessariamente sob a lógica da ponderação. Ponderação, racionalidade e atividade jurisdicional. Rio de Janeiro: Renovar, 2005. p. 24, 35 e 36.

${ }^{61} \mathrm{Na}$ doutrina, vislumbramos ÁVILA, Humberto como expoente desse conceito ao afirmar que "não se pode estremar a interpretação da ponderação".Teoria dos princípios: da definição à aplicação dos princípios jurídicos. 4. ed. rev. São Paulo: Malheiros, 2004. p.47. 
uma análise de razões e contra-razões. É certo, também, que na resolução de colisões de direitos fundamentais pelo método ponderativo sempre será realizada a análise de argumentos e contra-argumentos, os quais, contudo, dirão respeito à atribuição de pesos aos bens em colisão e não ao delineamento de conceitos e exceções.

Assim, cabe distinguir a ponderação de razões da ponderação de interesses. Aquela se relaciona a um conceito amplo, equivalente a interpretar, enquanto esta remete a uma técnica de decisão das colisões de direitos fundamentais.

Jane Reis Gonçalves Pereira apresenta uma série de diferenciações entre os dois conceitos de ponderação:

\begin{abstract}
"Enquanto no primeiro caso consideram-se apenas argumentos e contraargumentos, razões e contra-razões que recomendam a atribuição de certo sentido às categorias normativas ou o estabelecimento de uma exceção, no segundo, procura-se mensurar o peso circunstancial dos bens jurídicos em confronto, à luz da axiologia que deflui da Constituição e da moralidade social vigente. Enquanto no primeiro caso, cria-se uma regra de preferência - ou uma definição - que poderá ser aplicada a todos os casos posteriores em que se configure conflito entre os mesmos interesses em questão, no segundo estebelece-se uma relação de precedência válida apenas para aquele caso, ou melhor, válida apenas para casos em que os conflitos entre tais interesses ostentem as mesmas características." ${ }^{~}$
\end{abstract}

Assim, concluímos que ponderação e interpretação são conceitos diversos que devem ser apartados, pois a ponderação representa apenas uma das formas de interpretação com uma estrutura peculiar de argumentação que encontra diversos limites. Sua característica básica e primordial é que a solução criada por sua utilização não é válida para todos os casos em que estejam os mesmos direitos em colisão; apenas aqueles que porventura possuam circunstâncias idênticas devem ser resolvidos da mesma forma.

${ }^{62}$ PEREIRA, Jane Reis Gonçalves. Interpretação constitucional e direitos fundamentais: uma contribuição ao estudo das restrições aos direitos fundamentais na perspectiva da teoria dos princípios. Rio de Janeiro: Renovar, 2006. p.264. 


\subsubsection{Teoria da concordância prática}

A concordância prática foi inicialmente concebida como uma alternativa à ponderação. Desta forma a utilização desta técnica levaria à uma harmonização dos direitos fundamentais em conflito, enquanto a ponderação levaria sempre ao estabelecimento da prevalência de um dos direitos colidentes. Com o tempo, a concordância prática foi incorporada à técnica da ponderação, constituindo um ideal a ser buscado por esta na decisão dos casos difíceis.

A concordância prática, também conhecida como harmonização de direitos se baseia no princípio da unidade constitucional, considerando que as normas não são totalmente incompatíveis entre si, e realizando um esforço de harmonização dos direitos em tensão, de forma a prejudicar o mínimo possível a aplicação de cada um deles. Ou seja, realiza-se uma ponderação dos bens em conflito para tentar maximizar a aplicação de cada um deles no caso concreto, sacrificando o mínimo possível os direitos em jogo. Dessa forma, vamos otimizar os direitos em busca de um equilíbrio entre eles e com vistas a não sacrificar nenhum deles no caso concreto.

Porém, temos que perceber que a concordância prática entre os direitos conflitantes não pode ser entendida como regras matemáticas e automaticamente aplicáveis. Assim como não devemos privilegiar sacrifícios de uns direitos pelos outros, também não é aceitável uma redução igual e matematicamente explicável de ambos os direitos, pois isso levaria a situações incongruentes diante dos casos concretos. Como temos variados conflitos e várias formas de resolvê-los, devemos realizar uma ponderação com bases no caso concreto e na proteção dos interesses de ambas as partes, buscando dessa forma a máxima efetividade possível de todos os direitos Constitucionais, de forma a nenhum deles ser excluído.

Assim, a otimização dos vários interesses vai depender da forma como os direitos são afetados no caso concreto, consoante as possíveis alternativas de resolução do conflito, ou seja, atendendo ao seu conteúdo e 
função e ao peso atribuído a cada direito, vamos comprimir os direitos de formas diferentes nos variados casos.

Esse método visa, em concreto, a preservação dos interesses de ambas as partes e também da própria Constituição, não admitindo o sacrifício de seus direitos e conciliando a aplicação dos seus valores de forma a consagrar todos eles na maior proporção possível diante do caso concreto.

Dessa forma, o objetivo final da decisão ponderativa deve ser sempre o alcance da concordância prática dos bens em conflito, de forma que nenhum deles seja totalmente excluído. Porém, casos há que não permitem essa harmonização, pois um dos direitos afasta totalmente o outro. Aqui, a atribuição de pesos servirá diferentemente para determinar qual dos direitos irá preponderar temporariamente e qual será afastado. Isso não significa considerar que o outro princípio seja inválido e sim que no caso concreto os princípios são totalmente inconciliáveis e que têm diferentes pesos e importância, devendo prevalecer o que for maior nessas dimensões. $^{63}$

Conforme se afigura a concordância prática deve ser priorizada, pois a redução de ambos os direitos leva a um tratamento igual de todos. Mas em alguns casos não existe a possibilidade dessa aplicação simultânea dos direitos, utilizando-se então o método da ponderacão para definir a dimensão do peso e importância dos direitos perante o caso concreto e chegar a uma decisão fazendo prevalecer um deles.

\footnotetext{
${ }^{63}$ Reforce-se que a predominância e o consequente afastamento dos direitos é apenas temporário e restrito àquele caso concreto. Considere-se também que a concordância prática é um método possível na grande maioria dos casos e que o intérprete deve depreender esforços em busca da harmonização; só em situações extremas deve ser determinada uma preponderância e o afastamento indiscriminado e injustificado da harmonização pode dar ensejo a um retorno às teorias que determinam a prevalência e hierarquia de direitos, já ultrapassadas pelo método ponderativo e o grande avanço que este proporcionou.
} 


\subsubsection{Ponderação em abstrato e ponderação em concreto}

A ponderação, conforme a doutrina, pode se realizar em dois contextos: abstratamente ou diante do caso concreto.

A ponderação abstrata, também conhecida como definitional balancing, realiza-se de modo desvinculado de casos concretos. Assim, doutrina e jurisprudência fixam critérios abstratos de harmonização e eventual prevalência de direitos fundamentais colidentes, sem se basear em circunstâncias específicas.

Sendo assim, a discussão constante sobre certos aspectos poderia levar à formação de um banco de dados, podendo a partir deles haver um raciocínio ponderativo independentemente de um caso concreto, ou seja, pela observacão dos aspectos normalmente frequentes em um tipo de colisão de direitos fundamentais formariam-se soluções ponderativas préfabricadas. ${ }^{64}$

Como exemplo, poderemos citar o caso da colisão, extremamente comum, da liberdade de expressão, informação e imprensa, com a intimidade, a honra e a vida privada. Assim, no caso da criação de uma ponderação abstrata, analisaríamos os aspectos normalmente comuns como: a localização em local público ou privado como fator determinante de deliberação da esfera de intimidade; a veracidade ou não da informação como condição de possibilidade de sua publicação; a profissão como influenciadora do nível de proteção da vida privada. A partir da análise dessas questões poder-se-ía chegar a alguns raciocínios ponderativos que concluiriam, por exemplo, que no caso de pessoas públicas estas estariam mais acostumadas e submetidas à imprensa e ao interesse social, tendo então uma esfera de intimidade reduzida, ou que as informações verídicas e

\footnotetext{
${ }^{64}$ BARCELLOS, Ana Paula. Ponderação, racionalidade e atividade jurisdicional. Rio de Janeiro: Renovar, 2005. p. 150.
} 
de pessoas que se encontram em locais públicos não podem ser impedidas. $^{65}$

Com essas soluções ponderativas já determinadas, quando surgisse um caso semelhante ao analisado, o juiz já possuiria uma resposta pronta para aplicar, utilizando apenas o método da sunsunção; a colisão de direitos fundamentais constituiria, assim, um caso fácil perdendo sua caracterização como hard case.

Por outro lado, a ponderação em concreto, também conhecida como ponderação ad hoc, é aquela que perante uma situação de fato irá buscar uma solução para a colisão, baseando-se nas peculiaridades do caso concreto.

Esse raciocínio, já antes analisado, irá trazer uma solução específica para cada caso de conflito. Isso significa que em outro caso, no qual os direitos fundamentais em colisão se repitam, o intérprete poderá chegar a uma conclusão diferente devido às peculiaridades do caso.

Alexy ressalta essa afirmação ao asseverar que "o sopesamento não é um procedimento que conduza, em todo e qualquer caso, a um resultado único $(\ldots))^{\prime} .66$

Diante da análise dos dois métodos ponderativos, Ana Paula Barcellos defende a técnica da ponderação abstrata ao asseverar que "na verdade, mais que possível, é desejável que a ponderação se desenvolva também antes do surgimento do caso concreto". ${ }^{67}$ Sendo assim, a autora acentua que a ponderação em abstrato deve ocorrer em larga escala, restando para a ponderação ad hoc apenas os casos residuais, ou seja, apenas aqueles não abrangidos pela ponderação abstrata. Ressalta ainda,

\footnotetext{
${ }^{65}$ SARMENTO, Daniel traz como exemplo o entendimento jurisprudencial de que as hipóteses de prisão processual anteriores ao trânsito em julgado não contrariam o princípio constitucional da presunção de inocência, que apenas impediria o lançamento do nome do réu no rol de culpados. Assim afirma que "De fato, com esta posição, a jurisprudência tentou conciliar o princípio da presunção de inocência com o interesse constitucional na proteção da segurança pública, fazendo-o de modo abstrato, e não à luz de casos concretos". A ponderação de interesses na Constituição Federal. Rio de Janeiro: Lúmen Júris, 2003. p.110.

${ }^{66}$ ALEXY, Robert. Teoria dos Direitos Fundamentais. Traduzido por Virgílio Afonso da Silva. São Paulo: Malheiros Editores, 2008. p. 594.

${ }^{67}$ BARCELLOS, Ana Paula. Ponderação, racionalidade e atividade jurisdicional. Rio de Janeiro: Renovar, 2005. p. 147.
} 
que mesmo nesses casos a ponderação deverá se utilizar de certos standards da ponderação em abstrato e que caberia ao juiz justificar o porquê da situação não se adequar à aplicação dos modelos pré-existentes. ${ }^{68}$

Diversamente, posições há que consideram esse método, não como uma ponderação, mas apenas como um tipo de interpretação jurídica tradicional, visando definir os limites dos direitos fundamentais.

Daniel Sarmento, adepto dessa posição, considera ainda que é certo que, com o passar do tempo, a jurisprudência cria certos standards para a solução de colisões, reduzindo a subjetividade do intérprete na análise de casos análogos. Porém ressalta que isso não gera a substituição das ponderações ad hoc por regras rígidas de solução de colisões. ${ }^{69}$

Jane Reis Gonçalves Pereira também sustenta essa posição, preocupando-se, porém, em diferenciar a ponderação em abstrato da categorização:

"Trata-se, em suma, de precisar o conteúdo das normas em confronto, dando à questão conflituosa uma solução que demarca, de forma definitiva, o perímetro constitucional dos direitos em jogo. Sem embargo a ponderação definitória pode ser diferenciada da categorização, pois naquela o peso do interesse que justifica a restrição ao direito fundamental é considerado para definir seu alcance, enquanto nesta se procura apenas enquadrar os fatos numa determinada categoria estabelecida na Constituição."70

Conclui-se que a ponderação abstrata apresenta vantagens, evitando ponderações que poderiam ser desnecessárias, porém, não pode ser confundida com o a ponderação em concreto que não deve ter sua importância desconsiderada.

\footnotetext{
${ }^{68}$ BARCELLOS, Ana Paula. Ponderação, racionalidade e atividade jurisdicional. Rio de Janeiro: Renovar, 2005. p.146 a 155.

${ }^{69}$ SARMENTO, Daniel. A ponderação de interesses na Constituição Federal. Rio de Janeiro: Lúmen Júris, 2003. p. 110 e 111.

${ }^{70}$ PEREIRA, Jane Reis Gonçalves. Interpretação constitucional e direitos fundamentais: uma contribuição ao estudo das restrições aos direitos fundamentais na perspectiva da teoria dos princípios. Rio de Janeiro: Renovar, 2006. p.270.
} 


\subsubsection{Proposta de ponderação em três etapas}

Com vistas a possibilitar uma simplificação do método ponderativo para sua aplicação pelo intérprete tornar-se mais clara e também para facilitar o controle da racionalidade do intérprete em sua utilização, surgiu na doutrina uma proposta de ordenação da ponderação em três etapas sucessivas. $^{71}$

De forma simplificada essas etapas seriam: análise e identificação dos direitos fundamentais em colisão; análise da relevância dos fatos concretos e suas repercussões; e atribuição de pesos para a formação da decisão. $^{72}$

Na primeira etapa serão identificados os enunciados normativos ${ }^{73} \mathrm{em}$ conflito. É de grande importância a correta e completa identificação dos enunciados pelo intérprete, pois o esquecimento de um enunciado envolvido enfraquece a posição por ele sustentada, gerando um consequente fortalecimento da posição oposta.

Também se demonstra de extrema importância a identificação e diferenciação dos interesses e dos enunciados normativos. Isso porque é comum que os interesses em oposição tornem-se mais relevantes que os enunciados normativos envolvidos, mas devemos considerar que os interesses só devem ser relevados se reproduzirem enunciados normativos

\footnotetext{
71 BARCELLOS, Ana Paula, traz uma análise completa e aprofundada sobre as etapas da ponderação. Para maiores detalhes e aprofundamentos : . Ponderação, racionalidade e atividade jurisdicional. Rio de Janeiro: Renovar, 2005. p. 91 a 146.

72 ÁVILA, Humberto traz uma divisão um pouco diferente ao determinar as três fases como: preparação da ponderação, com a análise de todos os argumentos; realização da ponderação, com a atribuição de pesos; e reconstrução da ponderação, com formulação de regras de primazia gerando pretensão de validade para além do caso. Teoria dos princípios: da definição à aplicação dos princípios jurídicos. 4. ed. rev. São Paulo: Malheiros, 2004. p.94 a 96.

${ }^{73}$ BARCELLOS, Ana Paula ressalta que serão identificados os enunciados normativos e não as normas diferenciando estas daqueles ao determinar que os enunciados normativos constituem o texto expresso podendo também serem implícitos ou decorrerem do sistema como um todo enquanto as normas seriam comandos específicos que dão solução a um caso. Assim ressalta que a ponderação é uma técnica para determinar a norma de solução do caso a partir dos diferentes enunciados normativos envolvidos. Ponderação, racionalidade e atividade jurisdicional. Rio de Janeiro: Renovar, 2005. p. 103 a 112.
} 
implícitos ou explícitos. De forma inversa, interesses que não apresentem nenhuma conexão com a ordem jurídica não deverão ser considerados pelo intérprete em sua análise.

Ilustrativamente apresenta-se o exemplo de um vizinho que deseja que a construção de um edifício, totalmente legalizada, ao lado de sua casa, não seja realizada, pois atrapalharia sua visão do bosque e a tranquilidade da rua. Nesse caso, a pretensão do vizinho não encontra amparo em nenhum enunciado normativo específico que garanta a visão do bosque nem a tranquilidade da rua, tratando-se de mero interesse contraposto ao direito de propriedade de quem visa construir um edifício de forma regular. Poderia o vizinho, porém, alegar o princípio de proteção ao meio ambiente equilibrado e à vida sadia, ressaltando que a falta da vista, a qual já tinha há tantos anos, tornara-se essencial para sua qualidade de vida e que, além disso, o prédio geraria tumulto prejudicando o meio ambiente e a vida sadia dos moradores da rua. Desta forma, caberia a ele alegar os direitos consagrados no art. 225 da Constituição Federal em oposição ao direito de propriedade e de construir do proprietário do edifício, mas jamais poderia ser considerado um direito a não construção do edifício, pois este representa mero interesse e não encontra amparo no ordenamento jurídico.

Sendo assim, nesta primeira etapa, os interesses das partes deverão ser descritos juridicamente, visando preservar a legitimidade da ponderação e servindo de razão contra as críticas do método.

Na segunda etapa, deve o intérprete analisar as circunstâncias do caso concreto para determinar sua relevância para os direitos colidentes. Essa etapa será composta de dois pasos.

Primeiramente o intérprete realizará esforços em destacar de forma fundamentada os fatos relevantes. Por exemplo, no caso de confronto entre a liberdade de imprensa e proteção da vida privada, a profissão do indivíduo pode assumir maior ou menor relevância para o caso. Isso porque notícias sobre uma pessoa comum podem não ter a mesma importância que notícias 
sobre pessoas públicas, como por exemplo, o Presidente da República. Assim, o caso de um noticiário sobre o uso de entorpecentes e a necessidade de internação de uma pessoa comum pode não assumir a mesma relevância de notícia referente ao Presidente ou a um Deputado Federal, isso porque, há um maior interesse social nesse tipo de notícia quando se relaciona a titulares de cargos eletivos. Também nesse caso a cor dos olhos ou dos cabelos da pessoa que será internada não adquire relevância para a notícia do crime.

Ressalte-se que a decisão dos fatos relevantes pode assumir contornos complexos dependendo do caso, gerando dificuldades para o intérprete em sua determinação.

Em um segundo passo deve o intérprete analisar qual a influência que os fatos considerados relevantes irão exercer na atribuição dos pesos aos bens conflitantes. As repercussões dos fatos podem se dar de duas formas: podem indicar um peso maior ou menor para os enunciados envolvidos ou determinar o grau de restrição que a escolha de cada uma das soluções possíveis pode impor sobre as demais naquele caso. ${ }^{74}$

Sendo assim, seria possível determinar, a partir dos fatos relevantes, graus de restrição diferenciados de forma a analisar se a restrição, perante o caso concreto, seria de grande valor ou insignificante. Desta forma, havendo diversos meios de realizar os direitos colidentes, deve-se escolher a forma que represente uma menor restrição aos direitos.

Cabe ao intérprete a análise de todas as possibilidades de realização do direito em conflito e das restrições que elas impõem, para assim verificar se há uma possibilidade de atender a todos os direitos em conflito, sendo essa análise de grande importância para a última etapa.

$\mathrm{Na}$ terceira e última etapa, o intérprete irá determinar o peso dos princípios para assim tomar a decisão do caso.

\footnotetext{
${ }^{74}$ BARCELLOS, Ana Paula. Ponderação, racionalidade e atividade jurisdicional. Rio de Janeiro: Renovar, 2005. p. 121.
} 
Essa etapa é a que representa maior dificuldade para a atividade do exegeta, pois o método ponderativo não estabelece critérios precisos para a definição dos pesos dos direitos colidentes, devendo o intérprete levar em conta o trabalho realizado nas outras duas etapas e algumas diretrizes gerais, dentre elas, a capacidade de universalização dos argumentos empregados e da decisão em si; a busca pela concordância prática; e o respeito aos limites da ponderação.

A capacidade de universalização resvala duas necessidades. Em primeiro lugar, deve haver a busca de uma argumentação universal, aceita pelo sistema jurídico e por toda a sociedade e que se considere compreensível de forma racional. Deste modo, deve o juiz, ao justificar sua decisão adotar argumentos passíveis de serem aceitos pela sociedade como um todo e não argumentos baseados em ideais de grupos restritos.

Em segundo lugar, a própria decisão tomada pelo intérprete deverá possibilitar uma universalização para situações equivalentes, ou seja, a decisão deve poder ser aplicada na análise de outro caso que apresente os mesmos direitos colidentes e circunstâncias iguais ao que se decidiu. Essa necessidade decorre do dever de isonomia que determina que aqueles que se encontram em situações iguais devem receber tratamento equivalente do Poder Judiciário.

Outra diretriz, já anteriormente analisada, é a busca pela concordância prática. Nessa dimensão, utilizando-se do raciocínio da segunda etapa, o intérprete deve escolher a solução que determine um maior equilíbrio e uma menor restrição aos direitos colidentes. Então, devemos levar em conta as considerações já antes feitas sobre a concordância prática, restando considerar que em certos casos esta não será possível, pois a adoção de um dos direitos implicará no total afastamento do outro; nesses casos, após a atribuição de pesos irá preponderar temporariamente o que apresentar maior peso no caso concreto. 
Por fim, a última diretriz a ser seguida na tomada de decisão é o respeito aos limites da proporcionalidade, razoabilidade e do núcleo essencial dos direitos fundamentais, que serão enunciados mais à frente.

\subsubsection{Críticas a ponderação}

Diversas são as críticas que foram apontadas contra o método ponderativo e sua utilização na resolução dos conflitos de direitos fundamentais. Dentre elas, são três os principais argumentos levantados: o esvaziamento dos direitos fundamentais ocasionados pela utilização do método ponderativo; a inconsistência metodológica do método e a violação da separação de poderes.

A análise dessas críticas constitui instrumento importante não apenas para, refutando-as, reforçar a necessidade e a viabilidade do método, mas também para analisar suas falhas e buscar meios para solucioná-las aprimorando, assim, a ponderação como técnica e evitando que se utilizem dela em nome de ideais subjetivos e arbitrários.

Primeiramente, analisaremos a crítica que imputa à ponderação o esvaziamento dos direitos fundamentais. Essa crítica é sustentada com base no raciocínio de que o método ponderativo tornaria as disposições constitucionais de direitos fundamentais fracas e reduziria sua importância, pois a certeza e a previsibilidade de sua aplicação seriam reduzidas diante da possibilidade de estes sofrerem restrições.

Desta forma, ao invés da certeza e previsibilidade que deveria marcar sua aplicação, os direitos fundamentais estariam submetidos à ponderação, tornando-se direitos relativos e dependentes da interpretação do exegeta.

Os defensores dessa crítica afirmam ainda que o intérprete aplicaria o direito conforme o entendimento da maioria e, que os direitos fundamentais deveriam estar a salvo até desses rumores e também que, 
mesmo submetidos às maiorias, a consideração de suas opiniões não estaria sendo realizada por um órgão que, eleito por ela, a represente. ${ }^{75}$

A referida crítica ainda se baseia na falta de previsão constitucional a embasar a restrição a seus direitos, não podendo o Poder Judiciário decidir livremente quando aplicá-los ou não. A adoção da ponderação deixaria, portanto, os direitos fundamentais submissos à decisão do Poder Judiciário de tutelar sua aplicação.

Apesar da importância da crítica ora apresentada, que alerta para o possível esvaziamento dos direitos fundamentais, devemos considerar que como demonstrado, os conflitos de direitos fundamentais são inevitáveis e que diante deles alguma restrição deverá ser aplicada para conciliando os direitos em conflito, garantirmos o postulado da unidade da Constituição.

Assim, a ponderação demonstra-se necessária, permitindo a resolução dos conflitos com busca a instituir a menor restrição possível aos direitos em tensão e se baseando na persecução da convivência entre eles. A ponderação nos parece, então, favorecer mais os direitos fundamentais que o estabelecimento de uma hierarquia entre eles, pois esta tornaria letra morta os direitos menos graduados. ${ }^{76}$

A segunda crítica apresentada ressalta a inconsistência metodológica da ponderação e sustenta que por esta não apresentar métodos de determinação de seu resultado e de atribuição de pesos aos direitos fundamentais tornar-se-ia um meio de ocultar uma tendência ao "decisionismo judicial", baseado apenas na subjetividade e discricionariedade do juiz. Assim, pela inexistência de parâmetros de controle dos sopesamentos apontam que o método seria permeado por subjetivismos e irracionalidade, levando à arbitrariedade e violando a segurança jurídica.

\footnotetext{
${ }^{75}$ BARCELLOS, Ana Paula. Ponderação, racionalidade e atividade jurisdicional. Rio de Janeiro: Renovar, 2005. p. 52 e 53.

${ }^{76}$ SARMENTO, Daniel. A ponderação de interesses na Constituição Federal. Rio de Janeiro: Lúmen Júris, 2003. p. 145.
} 
Essa crítica não deve ser menosprezada por colocar "em pauta o problema de saber se o juízo de ponderação pode ser reconstruído e explicado por meio de estratégias argumentativas racionais e passíveis de generalização." ${ }^{, 77}$

Seria tolo negar que o método da ponderação concede ao intérprete um amplo espaço de discricionariedade e de valoração. Ressaltando o caráter subjetivo do método, Daniel Sarmento ressalta que:

"No plano constitucional, é natural que esta carga de subjetivismo das decisões judiciais torne-se ainda mais acentuada do que nos outros ramos jurídicos, seja porque lida-se com questões coloridas por um forte matiz político, seja por predominarem na Constituição as normas abertas, cuja estrutura franqueia ao intérprete um espaço mais amplo para as valorações pessoais."

Contudo, o método ponderativo mostra-se capaz de permitir um controle da racionalidade de suas decisões com a utilização do princípio da proporcionalidade, da razoabilidade e do respeito ao núcleo dos direitos fundamentais, atuando como limites ao subjetivismo do intérprete. Também a exigência de fundamentação da decisão deverá permitir a análise da observância desses limites na atividade ponderativa, evitando ponderações baseadas em valores pessoais e morais.

Ademais, uma análise empírica da aplicação do método nos permite visualizar que as decisões tomadas com base na ponderação, normalmente, não se apresentam arbitrárias e subjetivas; pelo contrário, são, na maioria das vezes, devidamente fundamentadas em preceitos racionais e aceitáveis mesmo que permeadas por juízos políticos ou de valor. Além disso, é certo que para cada tese adotada, existirão sempre amplos defensores da tese contrária, principalmente nos casos complexos.

Assim, aceitar que a ponderação envolve certa discricionariedade não é o mesmo que caracterizá-la como método irracional e insuscetível de controles objetivos.

\footnotetext{
${ }^{77}$ PEREIRA, Jane Reis Gonçalves. Interpretação constitucional e direitos fundamentais: uma contribuição ao estudo das restrições aos direitos fundamentais na perspectiva da teoria dos princípios. Rio de Janeiro: Renovar, 2006. p.272.
} 
Ressalte-se, também, que todos os critérios antes apresentados possuem essa mesma dose de discricionariedade na definição das categorias, hierarquias ou limites. Desse modo, para a adoção do método ponderativo resta apenas análisar se este é capaz de apresentar critérios mais controláveis e racionais.

Acreditamos que a ponderação se apresenta como o método capaz de proporcionar maior controle e racionalidade à decisão, pois, se utilizarmos o raciocínio proposto, teremos uma fundamentação da decisão em cada etapa do processo poderativo, bem como deveremos nos pautar em limites determinados.

Diversamente, os outros critérios apresentados, por negarem seu viés subjetivo, acabam por se utilizar de raciocínios ponderativos mas, por negarem também o método, não apresentam uma fundamentação de sua escolha, permitindo ainda mais arbitrariedade e subjetivismo. Ou seja, no estabelecimento de hierarquias, categorias e limites o intérprete também é tomado por raciocínios valorativos, mas como a aplicação desses métodos pressupõe uma negação à ponderação e aos subjetivismos a ela inerentes acaba por colocar suas definições como absolutas sem fundamentar sua escolha.

De outro lado, é certo que a ponderação deve apresentar uma fundamentação abrangente, justificando todo e qualquer tipo de valoração envolvida na tomada de decisão. Apresenta-se, então, como critério capaz de oferecer maior transparência, por não negar sua dose de discricionariedade e apresentar em sua fundamentação o respeito aos limites a ela impostos.

A terceira e última crítica a ser analisada se refere à acusação de violação da separação de poderes, conferindo muito poder ao Judiciário em detrimento do Legislativo.

Assim, dizem que a ponderação viola o princípio democrático, ao permitir que órgãos não legitimados democraticamente, ou seja, que não 
forem eleitos pelo povo, decidam pela aplicação de direitos constitucionalmente consagrados.

Em rebate à crítica, devemos ressaltar que, como demonstrado, pode o legislador, de antemão, criar soluções para as colisões de direitos fundamentais e que só caberá ao Poder Judiciário a livre criação de soluções para esses conflitos quando não houver uma previsão legislativa. Desse modo, a ponderação não coloca em cheque a primazia do Poder Legislativo na tarefa de concretização da Constituição. ${ }^{78}$

Ocorre que, a colisão surge diante de casos concretos que apresentam circunstâncias variadas a serem consideradas diante do processo ponderativo. Assim, torna-se impossível para o Poder Legislativo prever todas as situações de conflito, bem como todas as circunstâncias que podem lhes permear, tornando-se necessária a atuação jurisdicional.

A separação de poderes não é mais concebida de forma absoluta, existindo a possibilidade de intervenção e exercício de funções próprias de um poder também pelos outros poderes. Desta forma, não mais se concebe o Poder Judiciário como mera boca da lei, restando para ele uma dimensão interpretativa e por vezes, criadora do direito.

Devemos, porém, considerar a importância da crítica de forma a impor limites ao método para que não se efetive como um instrumento antidemocrático.

Após sua análise, percebe-se que as críticas aduzidas à ponderação poderiam se aplicar à interpretação jurídica em geral, especialmente nos casos de aplicação de princípios. ${ }^{7 / 80}$

\footnotetext{
${ }^{78}$ SARMENTO, Daniel. A ponderação de interesses na Constituição Federal. Rio de Janeiro: Lúmen Júris, 2003. p. 148.

${ }^{79}$ BARCELLOS, Ana Paula. Ponderação, racionalidade e atividade jurisdicional. Rio de Janeiro: Renovar, 2005. p. 53 e 54.

${ }^{80}$ Ressalte-se que nem a técnica da subsunção é de tão fácil aplicação quanto parece. Não interessa ao presente trabalho aprofundamentos no tema, mas REALE, Miguel traz uma definição bastante precisa das dificuldades envolvidas no método subsuntivo ao afirmar que "podemos concluir que o ato de subordinação ou subsunção do fato à norma não é um ato reflexo e passivo, mas antes um ato de participação criadora do juiz, com sua sensibilidade e tato, sua intuição e prudência, operando a norma como substrato condicionador de suas indagações teóricas e técnicas.".Lições
} 
Assim, por mais que a ponderação abarque certa dose de subjetividade, diante da estrutura principiológica dos direitos fundamentais e da complexidade das questões das colisões, ela se estabelece e se consagra como método apto a criar soluções, baseada em parâmetros racionais e permitindo seu controle, tornando-se cada vez mais objetiva e transparente, por ter sua decisão circundada por limites à ela estabelecidos e que devem ser corretamente apresentados e fundamentados pelo intérprete.

\subsubsection{A lei de colisão e a lei de sopesamento de Robert Alexy como critérios de racionalidade}

Robert Alexy defende a utilização do método ponderativo ao afirmar a possibilidade de serem estabelecidos critérios racionais para seu controle.Ressalta esse caráter ao se referir às críticas apresentadas ao método:

"Essas objeções são procedentes se com elas se quiser dizer que o sopesamento não é um procedimento que conduza, em todo e qualquer caso, a um resultado único e inequívoco. Mas elas não são procedentes quando daí se conclui que o sopesamento é um procedimento não-racional ou irracional." ${ }^{\text {"81 }}$

Deste modo, o autor propõe a aplicação de duas leis - lei de colisão e lei de sopesamento - como meio de observação e controle do método ponderativo.

Ao discorrer sobre a lei de colisão, Alexy ressalta que o conflito entre princípios deve ser solucionado por meio do estabelecimento de "relações de precedência condicionada", ou seja, estabelece-se que diante de tais circunstâncias um dos princípios tem precedência sobre o outro; o que significa que diante de outras circunstâncias a decisão do intérprete

Preliminares de Direito. $27^{\mathrm{a}}$ ed. ajustada ao novo Código Civil. São Paulo: Saraiva, 2005. p.300 a 302.

${ }^{81}$ ALEXY, Robert. Teoria dos Direitos Fundamentais. Traduzido por Virgílio Afonso da Silva. São Paulo: Malheiros Editores, 2008. p. 164 
poderá ser completamente diferente. ${ }^{82}$ Deste modo, as precedências de direitos fundamentais não são absolutas e sim determináveis perante as condições do caso concreto.

Para o autor, a análise dessas relações de precedência levariam à criação de regras que determinariam que diante de tais circunstâncias certo direito deverá prevalecer. Nas palavras de Alexy a lei de colisão se enunciaria como "As condições sob as quais um princípio tem precedência em face de outro constituem o suporte fático de uma regra que expressa a consequência jurídica do princípio que tem precedência." ${ }^{83}$

A lei de colisão determina, então, que a toda ponderação corresponde uma regra que deverá ser aplicada a casos idênticos de forma meramente subsuntiva.

Ilustrativamente vejamos o caso Lebach que apresenta a situação na qual uma emissora de televisão germânica planejava exibir um documentário sobre um crime que culminou na morte de quatro soldados alemães e o roubo de armas utilizadas no cometimento de outros crimes. Porém um dos condenados, como cúmplice do referido crime, estava já perto de sua liberdade da prisão e entendia que a exibição do documentário, o qual apresentava seu nome e imagem, violaria seus direitos fundamentais de proteção da personalidade, ameaçando inclusive sua ressocialização. Assim, o autor ajuizou reclamação constitucional no Tribunal Constitucional Federal Alemão que constatou a existência de uma colisão entre o direito de proteção da personalidade e a liberdade de informação, que seria inconciliável, pois a proteção do primeiro direito em conflito levaria à proibição do documentário enquanto que a proteção do segundo levaria à sua exibição.

Seguindo essa linha, o Tribunal sustentou que a liberdade de informar possui uma prevalência geral no caso de informações atuais sobre

\footnotetext{
${ }^{82}$ ALEXY, Robert. Teoria dos Direitos Fundamentais. Traduzido por Virgílio Afonso da Silva. São Paulo: Malheiros Editores, 2008. p.96.

${ }^{83}$ ALEXY, Robert. Teoria dos Direitos Fundamentais. Traduzido por Virgílio Afonso da Silva. São Paulo: Malheiros Editores, 2008. p.99.
} 
criminosos, mas que perante as circunstâncias do caso em análise essa precedência deveria ser desconsiderada pois a situação não mais revestia interesse atual e colocaria em risco a ressocialização do autor, proibindo assim a apresentação do documentário.

Desse modo Alexy sustenta que o Tribunal, diante dessa ponderação, desenvolveu uma regra enunciada da seguinte forma "uma notícia repetida, não revestida de interesse atual pela informação, sobre um grave crime, e que põe em risco a ressocialização do autor, é proibida do ponto de vista dos direitos fundamentais". ${ }^{84}$ Assim, todo caso que preenchesse os pressupostos enunciados na regra deveria ter sua aplicação exigida.

A criação de uma regra, a partir do resultado das ponderações, tornaria o critério mais racional e controlável por determinar sobre quais circunstâncias deve um direito prevalecer e também por favorecer a pretensão de universalização das decisões, pois, em um caso que apresente as mesmas circunstâncias de fato deverá ser observada a mesma regra de precedência já utilizada.

Ainda na busca por critérios de racionalidade Alexy enunciou a lei do sopesamento que determina que: "quanto maior for o grau de nãosatisfação ou de afetação de um princípio, tanto maior terá de ser a importância da satisfação do outro.",85

Essa lei é considerada como correspondente ao subprincípio da proporcionalidade em sentido estrito por assentar o raciocínio ali desenvolvido.

A criação dessa lei teve como objetivo rebater as críticas formuladas por diversos autores que alegavam não ser possível existir decisão racional se baseada no método da ponderação. Então, Alexy defende que é sim possível o estabelecimento de critérios racionais para os sopesamentos e propõe uma graduação em três níveis: grave, médio e leve.

\footnotetext{
${ }^{84}$ Para mais detalhes sobre o caso: ALEXY, Robert. Teoria dos Direitos Fundamentais. Traduzido por Virgílio Afonso da Silva. São Paulo: Malheiros Editores, 2008. p. 99 a 103.

${ }^{85}$ ALEXY, Robert. Teoria dos Direitos Fundamentais. Traduzido por Virgílio Afonso da Silva. São Paulo: Malheiros Editores, 2008. p. 593.
} 
Desta forma, os critérios de graduação seriam utilizados para conferência de valores a duas grandezas; de um lado dever-se-ia definir o nível da restrição ou afetação de um dos direitos e de outro o grau de importância da razão da restrição, ou melhor dizendo, a grandeza da importância da satisfação do outro direito.

A partir da análise desses juízos o intérprete irá determinar o sopesamento e poderíamos controlar a racionalidade de sua decisão, pois esta deve ser fundamentada com base nesses aspectos, motivando-se o grau atribuído a cada grandeza.

Poder-se-ia determinar então que uma restrição considerada média em face de uma razão de restrição considerada grave deve prevalecer, ao passo que, uma restrição considerada grave e uma razão de restrição considerada leve não deve prevalecer.

Um exemplo, trazido pelo autor, torna a questão elucidativa. Trata-se da obrigação de as indústrias de tabaco reproduzirem em seus produtos anúncios que alertam para o risco causado por seu consumo. Nesse caso teríamos uma colisão entre o direito à saúde e o direito à liberdade profissional. $\mathrm{O}$ autor avalia o grau de restrição causado à liberdade profissional como leve, determinando que a proibição total da venda de cigarros seria uma intervenção grave e que entre elas, uma intervenção média poderia ser constituída pela proibição de máquinas automáticas de venda de cigarros e uma restrição da venda desses produtos em determinados estabelecimentos.

De outro lado, os avisos impressos nos produtos visam proteger a saúde da população de um consumo que pode gerar diversas doenças como câncer e problemas vasculares; assim, as razões que justificam a intervensão teriam um grande peso, sendo consideradas como grave.

Desta forma, seria fácil perceber a necessidade de preservação da saúde com a manutenção da imposição aos produtores de tabaco, pois a restrição ou afetação de seu direito seria apenas leve, enquanto a razão da 
restrição ou importância da satisfação do outro direito seria considerada grave.

Ressalte-se ainda que se um intéprete considera a restrição como grave a o objetivo de proteção da saúde como leve esses juízos não poderiam ser considerados de forma séria, demonstrando-se assim, a possibilidade de controle racional por meio da aplicação da lei de sopesamento. $^{86}$

Percebe-se, então, que a lei de sopesamento, juntamente com a lei de colisão são critérios capazes de conferir um maior controle racional das decisões ponderativas.

\subsubsection{Motivação das decisões ponderativas.}

A Constituição Federal em seu artigo 93, inciso IX, exige que toda decisão judicial seja motivada, levando a público as razões que sustentam sua determinação.

Salienta-se então a importância de a decisão tomada ser sempre muito bem fundamentada, de forma que as partes possam compreender o porquê das restrições aos seus direitos em favor do direito da outra parte; o porquê do sacrifício de parte do seu direito.

Deste modo, o julgador deve sempre apresentar suas motivações para aquele resultado, o que não se afigura diferente perante as colisões de direitos fundamentais, nos quais essa motivação torna-se ainda mais importante, pois o conflito de direitos é muito incerto e não comporta verdades prévias, inseridas na legislação. Nesse caso temos apenas direitos conflitantes, ambos garantidos pelo mesmo diploma, sem existirem regras sobre a importância de cada um deles.

Sendo assim, como serão direitos a serem igualmente garantidos, torna-se tarefa árdua para o intérprete da lei decidir sobre como ponderá-

\footnotetext{
${ }^{86}$ Para maiores considerações: ALEXY, Robert. Teoria dos Direitos Fundamentais. Traduzido por Virgílio Afonso da Silva. São Paulo: Malheiros Editores, 2008. p. 593 a 611.
} 
los, bem como se torna difícil para as partes entender os critérios e meios utilizados nessa ponderação. Deve, então, o intérprete, motivar a sua decisão com grande clareza de idéias, expondo seu raciocínio passo a passo, para que as partes possam entender a razão de ser daquelas conclusões.

Luis Roberto Barroso nos fornece três parâmetros para podermos fazer o controle da argumentação utilizada, especialmente nos casos onde se utiliza a técnica da ponderação. O primeiro deles consiste na apresentação de argumentos normativos, mesmo que implícitos, para apoiar e sustentar a decisão, isso porque nos encontramos dentro de uma ordem jurídica, e devem ser levados em conta referências dessa ordem na solução dos litígios. Nos casos onde a técnica da ponderação está envolvida essa exigência torna-se ainda mais difícil, pois o caminho do julgador é mais incerto até uma conclusão, sendo necessário que ele exponha de forma ainda mais completa seu raciocínio, permitindo que as partes possam controlar a decisão. O segundo parâmetro referido é sobre a possibilidade de universalização dos critérios adotados pelo julgador em sua decisão, ou seja, deve ser analisada a hipótese de se estender esse critério utilizado aos casos semelhantes de forma a ter facilitada a visualização de incoerências e desvios na decisão. O terceiro e último parâmetro vai utilizar dois conjuntos de princípios para balizar a argumentação jurídica: "princípios instrumentais e específicos de interpretação constitucional e princípios materiais propriamente ditos, que trazem em si a carga ideológica, axiológica e finalística da ordem constitucional". Sendo assim, deve o intérprete balizar sua decisão, utilizando os princípios instrumentais e específicos de interpretação constitucional para atingir os ideais visados pelos princípios materiais. ${ }^{87}$

Ressalte-se que quanto maior o grau de subjetividade das decisões mais relevante torna-se sua motivação, exigindo-se dela maior clareza e completude de argumentos racionalmente controláveis. Nesses casos, deve

${ }^{87}$ BARROSO, Luis Roberto. Interpretação e aplicação da constituição: fundamentos de uma dogmática constitucional transformadora. 6. ed. rev., atual. e ampl. São Paulo: Saraiva, 2004.p. 362 a 369. 
o intérprete demonstrar com clareza todas as valorações envolvidas em sua decisão, justificando a adoção ou o afastamento de cada uma delas e evitando a tentativa frequente de esconder a ponderação sob as vestes de uma falsa subsunção.

Essa atividade de fundamentação, se realizada corretamente, permite o controle das decisões judiciais ${ }^{88}$, evitando decisões arbitrárias e subjetivas, e determina também a necessidade de universalização dos argumentos utilizados, pois estes devem representar um raciocínio passível de se aplicar à sociedade como um todo e não apenas a grupos de indivíduos. Assim, na decisão ponderativa, deve o juiz delinear todo seu raciocínio, passando por cada etapa do procedimento ponderativo e ressaltando o respeito aos limites da ponderação, que serão explicitados a seguir.

${ }^{88}$ SARMENTO, Daniel ressalta esse aspecto ao considerar que "a motivação dos atos jurisdicionais objetiva emprestar-lhes transparência e controlabilidade, não apenas para as partes do processo (controle endoprocessual), como também para a sociedade em geral (controle extraprocessual), que terá como avaliar criticamente os atos do Poder Judiciário, a partir dos valores sociais vigentes a cada momento. A motivação colima, assim, entre outras coisas, persuadir a coletividade da correção da decisão, buscando obter sua adesão racional.”. A ponderação de interesses na Constituição Federal. Rio de Janeiro: Lúmen Júris, 2003. p. 118. 


\section{Capítulo III - Limites à ponderação de direitos fundamentais}

Como visto, o método ponderativo não constitui tarefa de fácil realização e sofre diversas críticas. A possibilidade de ponderação vai de encontro ao caráter vinculante dos direitos fundamentais e suscita dúvidas sobre a sua integridade como método de aplicação do direito por estar, de certa forma, afeta à discricionariedade do intérprete. Devido a essa situação surge a necessidade da imposição de limites à atuação do intérprete na utilização do método ponderativo.

Esses limites servem de instrumentos para o controle da atividade ponderativa, e consequentemente da discricionariedade do intérprete, garantindo, assim, a operacionalidade dos direitos fundamentais com a aplicação de critérios que tornem possível um controle racional das decisões de prevalência de um direito sobre o outro.

Muitas vezes, os citados limites não se encontram positivados de forma explícita no texto constitucional, porém, por serem imanentes à proteção dos direitos, isso não impede sua aplicação e utilização como métodos válidos e perfeitamente aplicáveis.

\subsection{Razoabilidade e proporcionalidade}

A razoabilidade e a proporcionalidade são de extrema importância para o pensamento e a interpretação constitucional, constituindo bases para o controle da ponderação de direitos fundamentais.

Muito se discute a respeito de serem, a razoabilidade e a proporcionalidade noções equivalentes.

$\mathrm{Na}$ aproximação das noções surgem argumentos que ressaltam estarem ambas vinculadas a ideais de moderação e racionalidade e trazerem parâmetros de aferição da legalidade das decisões ponderativas, sendo assim, pautas para o processo da ponderação. Porém, vislumbra-se que a 
noção de razoabilidade é mais fluída e difusa, sendo a proporcionalidade dividida em uma análise em três níveis mais precisos e concretos.

A idéia de razoabilidade surgiu no direito norte americano, sendo derivada do devido processo legal, enquanto a proporcionalidade tem suas raízes no direito germânico que consagrou sua divisão tripartite. Sendo assim, muitos consideram que são noções correspondentes apenas com diferenças de surgimento histórico. A doutrina e a jurisprudência brasileiras, em sua maioria, se filiam a esse posicionamento que vislumbra os conceitos como noções fungíveis. Sob a ótica de Daniel Sarmento:

"Pode-se ainda dizer que, em linhas gerais, os princípios da proporcionalidade e razoabilidade, conquanto decorrentes de matrizes históricas diferentes, na prática são fungíveis, pois almejam o mesmo resutado: coibir o arbítrio do Poder Público, invalidando leis e atos administrativos caprichosos, contrários à pauta de valores abrigada pela Constituição" ${ }^{" 89}$

Nesse trabalho, porém, adotaremos uma posição de diferenciação da razoabilidade e da proporcionalidade, tratando-as como limites complementares a serem aplicados de forma conjunta na ponderação de direitos fundamentais. Isso porque a proporcionalidade abriga estrutura própria, dividida em três níveis, e será assim considerada, enquanto a racionalidade irá abranger outros juízos, conceitos e objetivos não tratados pela proporcionalidade e seus subprincípios.

\subsection{A proporcionalidade e sua estrutura tripartite}

A utilização da proporcionalidade é essencial à atividade ponderativa, pois o raciocínio utilizado em sua estrutura tripartite é exatamente o que deve ser considerado na ponderação de direitos fundamentais. Sendo assim, a proporcionalidade permite uma correta relação de sopesamento entre os princípios em jogo, permitindo uma solução que maximize a aplicação de ambos no caso de conflito. Nesse

\footnotetext{
${ }^{89}$ SARMENTO, Daniel. A ponderação de interesses na constituição federal. Rio de Janeiro: Lumen Juris, 2002. p. 87
} 
sentido ressalta-se que a proporcionalidade deve ser vista como o "princípio dos princípios" na manutenção dos direitos fundamentais conflitantes.

Diante disso, considera-se que a ponderação e a proporcionalidade são as faces de uma mesma moeda ${ }^{90}$ não permitindo que a ponderação seja considerada como método puramente discricionário e justificando o fato de ela não representar "uma forma de decisionismo judicial disfarçado, já que seu método pauta-se pelo princípio da proporcionalidade, cujos critérios podem ser aferidos com certa objetividade" ${ }^{, 91}$. Vislumbra-se assim a extrema importância da proporcionalidade para a proteção dos valores constitucionais.

O princípio da proporcionalidade vai avaliar a correlação entre os fins visados e os meios utilizados na ponderação de direitos fundamentais. Então, diante do caso concreto, teremos que ter uma finalidade a ser atingida, um meio a ser empregado para seu alcance e uma relação de causalidade entre eles, possibilitando assim a análise dos subprincípios da proporcionalidade, quais sejam: adequação, necessidade e proporcionalidade em sentido estrito.

Não estando presentes esses elementos, não será possível o exame da proporcionalidade, como acentua Humberto Ávila "sem uma relação meio/fim não se pode realizar o exame do postulado da proporcionalidade, pela falta dos elementos que o estruturem. "92

No caso dos conflitos de direitos fundamentais, torna-se importante destacar a finalidade pretendida, qual seja, a solução do conflito com a máxima aplicação dos direitos envolvidos e o meio utilizado, configurado pela aplicação da técnica da ponderação.

Devido ao fato de o princípio da porporcionalidade não estar explícito no texto constitucional, muito se discute sobre seu fundamento

\footnotetext{
90 SARMENTO, Daniel. A ponderação de interesses na constituição federal. Rio de Janeiro: Lumen Juris, 2002. p.96

91 SARMENTO, Daniel. A ponderação de interesses na constituição federal. Rio de Janeiro: Lumen Juris, 2002. p.96.

92 ÁVILA, Humberto. Teoria dos princípios: da definição à aplicação dos princípios jurídicos. 4. ed. rev. São Paulo: Malheiros, 2004. p . 114
} 
normativo. Diante das várias possibilidades, a que parece melhor explicar sua aplicação é a que se afilia às noções de Robert Alexy, determinando que a proporcionalidade surge da estrutura normativa dos direitos fundamentais como princípios. Ou seja, por serem os princípios mandamentos de otimização podem ser aplicados em graus variados, sendo normas que "ordenam que algo seja realizado na maior medida possível dentro das possibilidades jurídicas e fáticas existentes. "93

Sendo assim, em caso de conflito, os direitos exigem uma análise acerca das possibilidades de seu escalonamento para uma maior ou menor realização dos princípios neles consubstanciados. Essa análise será realizada com a utilização do postulado normativo da proporcionalidade que permitirá, diante do caso concreto, uma análise das possibilidades fáticas, por meio da adequação e da necessidade, e das possibilidades jurídicas, por intermédio da proporcionalidade em sentido estrito.

Por fim, resta considerar a discussão de se considerar a proporcionalidade como regra ou como princípio.

$\mathrm{Na}$ maioria das vezes a proporcionalidade é vista como princípio constitucional, estando a expressão consagrada pelo uso ${ }^{94}$.

Porém essa classificação é extremamente criticada, pois sua colocação como princípio traria em si a noção de mandado de otimização, que poderia ser realizado em graus variados. Essa aplicação em escalas não corresponde à aplicação do princípio da proporcionalidade, sendo adotada por Robert Alexy, como método de classificação, a nomenclatura de máxima:

"A máxima da proporcionalidade é com frequencia denominada "princípio da
proporcionalidade". Nesse caso, no entanto, não se trata de um princípio no
sentido aqui empregado. A adequação, a necessidade e a proporcionalidade em
sentido estrito não são sopesadas contra algo. Não se pode dizer que elas às vezes
tenham precedência e outras não. O que se indaga é, na verdade, se as máximas
parciais foram satisfeitas ou não, e sua não-satisfação tem como consequência

\footnotetext{
${ }^{93}$ ALEXY, Robert. Teoria dos Direitos Fundamentais. Traduzido por Virgílio Afonso da Silva. São Paulo: Malheiros Editores, 2008. p.90.

${ }^{94}$ PEREIRA, Jane Reis Gonçalves. Interpretação constitucional e direitos fundamentais: uma contribuição ao estudo das restrições aos direitos fundamentais na perspectiva da teoria dos princípios. Rio de Janeiro: Renovar, 2006. p. 322.
} 
uma ilegalidade. As três máximas parciais devem ser, portanto, consideradas como regras." 95

Em outra classificação, Humberto Ávila considera a proporcionalidade como um postulado normativo aplicativo, determinando que a proporcionalidade não pode ser classificada como regra nem como princípio.

$\mathrm{Na}$ visão do autor classificá-los em uma dessas categorias geraria uma imensa confusão, pois o funcionamento da proporcionalidade difere muito das regras e dos princípios.

“ Diversamente, os postulados, não impõem a promoção de um fim, mas, em vez disso, estruturam a aplicação do dever de promover um fim; de outro, não prescrevem indiretamente comportamentos, mas modos de raciocínio e de argumentação relativamente a normas que indiretamente prescrevem comportamentos. Rigorosamente, portanto, não se podem confundir princípios com postulados. As regras, a seu turno, são normas imediatamente descritivas de comportamentos devidos ou atributivas de poder. Distintamente, os postulados não descrevem comportamentos, mas estruturam a aplicação de normas que o fazem." 96

Ou seja, o autor define postulados como normas estruturantes de regras e princípios que demandam a ordenação e a relação entre vários elementos. $^{97}$

Essa classificação do referido autor demonstra, sem dúvida, uma importante versão da proporcionalidade de estruturar a aplicação das normas, porém não se deve desconsiderar que a proporcionalidade é uma norma metodológica que ou se aplica ou não se aplica, não sendo possível uma aplicação parcial, podendo assim ser classificada como regra.

Também devemos considerar que não é pela classificação da proporcionalidade como regra, máxima ou postulado normativo que devemos desconsiderar a linguagem habitual já firmada na prática jurídica do nosso país. Sendo assim, devemos considerar que ao falarmos de

\footnotetext{
${ }^{95}$ ALEXY, Robert. Teoria dos Direitos Fundamentais. Traduzido por Virgílio Afonso da Silva. São Paulo: Malheiros Editores, 2008. p.117 (nota de rodapé no ${ }^{\circ}$ ).

${ }^{96}$ ÁVILA, Humberto. Teoria dos princípios: da definição à aplicação dos princípios jurídicos. 4. ed. rev. São Paulo: Malheiros, 2004. p. 89.

${ }^{97}$ ÁVILA, Humberto. Teoria dos princípios: da definição à aplicação dos princípios jurídicos. 4. ed. rev. São Paulo: Malheiros, 2004. p. 90.
} 
princípio da proporcionalidade, tomamos a palavra "princípio" em uma acepção mais ampla, sem suscitar a contraposição a regras.

Diante disso, e demonstrada a aplicabilidade do princípio da proporcionalidade à ponderação, passemos à análise de suas máximas parciais ou subprincípios, que ajudam a compreender o que deve ser entendido por otimização dos princípios e auxiliam na atividade ponderativa servindo como limites à sua atuação. Ressalte-se que a análise da proporcionalidade não deve prescindir de nenhum de seus subprincípios, a ponderação, para ser proporcional, deve ser ao mesmo tempo, adequada, necessária e razoável.

\subsubsection{O subprincípio da adequação}

Esse subprincípio serve para a realização da análise de causalidade entre o meio e o fim, sem os quais o exame da proporcionalidade torna-se inviável.

Desta forma, será feita uma análise de congruência entre o meio e o fim, ou seja, vai ser analisada a relação meio/fim para determinar se o meio buscado é adequado para atingir o fim desejado.

Nessa análise deve-se atentar para duas fases, primeiramente deve-se considerar que o fim deve ser constitucionalmente legítimo, sendo necessário, em primeiro lugar, identificar o fim almejado e verificar se está de acordo com a ordem constitucional.

Após essa determinação, o intérprete deve aferir a aptidão do meio escolhido para atingir o fim perseguido.

Cabe considerar que a adequação do meio pode ser classificada em escalas diferentes, podendo o meio contribuir mais ou menos para o alcance do fim. Sendo assim, vários critérios podem contribuir para a aferição da adequação do meio, dentre eles cumpre destacar os critérios da adequação qualitativa e da adequação quantitativa. 
A adequação qualitativa vai analisar a eficácia para atingir o fim, sendo possível uma maior ou menor eficácia do meio escolhido. A adequação quantitativa vai analisar se o meio contribui mais ou menos para a obtenção do fim, se permite mais ou menos a implementação de seus aspectos.

Deve-se ainda considerar o aspecto temporal e o probabilístico. Pelo primeiro será feita uma análise de se o meio atua com maior ou menor rapidez para chegar ao fim, e pelo segundo será realizada a análise de se o meio promove com maior ou menor certeza o fim visado, gerando maior ou menor segurança quanto à sua obtenção.

Essa possibilidade de a adequação poder ser aferida em diversos graus gera problemas para a determinação de quando o meio será ou não adequado. Isso porque, devido à combinação de critérios, um meio pode ser mais eficaz para promover um fim, porém levar mais tempo ou ter menor certeza de êxito.

Devido a essa dificuldade, surgem duas correntes para se posicionar sobre a necessidade da adequação se apresentar em maior ou menor grau.

De um lado, a visão forte de adequação defende que para se atingir ao princípio da adequação o meio deve ser plenamente eficaz para atingir o fim, ou seja, deve realizá-lo de forma plena. De outro, a visão débil da adequação determina que o princípio será atingido, se o meio, de alguma forma, contribuir para o fim almejado, mesmo que parcialmente.

A visão débil é a mais adotada pela doutrina ${ }^{98}$ e pelos tribunais, mas traz em si um problema, porque apenas um meio completamente insuficiente para se atingir o fim seria considerado inadequado.

No caso da análise da ponderação, a adequação deve ser vista pelo prisma da restrição a um direito, demonstrar ser adequada a promover o outro direito, considerado como possuidor de um peso maior no caso

\footnotetext{
98 Nesse sentido, ÁVILA, Humberto. Teoria dos princípios: da definição à aplicação dos princípios jurídicos. 4. ed. rev. São Paulo: Malheiros, 2004. p. 117. "A administração e o legislador têm o dever de escolher um meio que "simplesmente" promova o fim."
} 
concreto. Se a restrição não promover de forma adequada o direito considerado de maior importância, essa não poderá ocorrer.

\subsubsection{O subprincípio da necessidade}

Nessa análise, cabe ao intérprete identificar se existiam meios alternativos ao escolhido que poderiam promover da mesma maneira o fim, sem restringir da mesma forma os direitos fundamentais afetados, ou seja, vai analisar se existe medida igualmente eficaz porém menos gravosa para se atingir o fim.

Dentre os vários meios para se atingir o fim, deve-se optar pelo menos oneroso. Sendo assim, será necessária uma análise comparativa do meio utilizado e dos outros possíveis para ver se realmente foi adotado o meio menos lesivo.

Existe proposta doutrinária de análise da necessidade em duas fases: primeiramente deve-se analisar se os meios alternativos atingiriam da mesma forma o fim visado; em segundo lugar realizar-se-ia o exame da existência de algum meio alternativo que afetasse em menor grau os direitos fundamentais. ${ }^{99}$

De acordo com Canotilho a necessidade pode ser avaliada de diversos pontos de vista, como o material, temporal, espacial e pessoal:

“ Dada a natural relatividade do princípio, a doutrina tenta acrescentar outros elementos conducentes a uma maior operacionalidade prática: a) a exigibilidade material, pois o meio deve ser o mais "poupado" possível quanto à limitação dos direitos fundamentais; b) a exigibilidade espacial aponta para a necessidade de limitar o âmbito da intervenção; c) a exigibilidade temporal prussupõe a rigorosa delimitação no tempo da medida coercitiva do poder público; d) exigibilidade pessoal significa que a medida se deve limitar à pessoa ou pessoas cujos interesses devem ser sacrificados." 100

\footnotetext{
${ }^{99}$ Explicitam essa proposta: ÁVILA, Humberto. Teoria dos princípios: da definição à aplicação dos princípios jurídicos. 4. ed. rev. São Paulo: Malheiros, 2004. p. 122 e PEREIRA, Jane Reis Gonçalves. Interpretação constitucional e direitos fundamentais: uma contribuição ao estudo das restrições aos direitos fundamentais na perspectiva da teoria dos princípios. Rio de Janeiro: Renovar, 2006. p. 339 a 341.

${ }^{100}$ CANOTILHO, J. J. Gomes. Direito Constitucional e Teoria da Constituição. $7^{\mathrm{a}}$ ed. Coimbra: Almedina, 2003. p. 270.
} 
Sendo assim, percebemos que também a necessidade poderá ser avaliada em diversos graus, traduzindo assim, uma certa dificuldade na determinação do meio menos oneroso.

Alexy compara o subprincípio da necessidade ao teorema de Pareto, determinando que:

"Nesse sentido também a máxima da necessidade é expressão da idéia de eficiência de Pareto. Em razão da existência de um meio que intervém menos e é igualmente adequado, uma posição pode ser melhorada sem que isso ocorra às custas da outra posição."

Ou seja, o meio deverá ser considerado desnecessário se vislumbrase, no caso concreto, outro meio igualmente eficaz que apresente menor restrição aos direitos fundamentais.

$\mathrm{Na}$ ponderação, o intérprete deve adotar sempre a medida menos gravosa possível para o direito fundamental a ser restringido. Deve-se buscar a menor restrição possível dos direitos fundamentais diante do caso concreto, ou dizendo-se de outra forma, deve-se buscar a maior aplicacão possível de todos os direitos em conflito.

\subsubsection{O subprincípio da proporcionalidade em sentido estrito}

Esse subprincípio expressa a estrutura lógica da ponderação ao realizar uma análise de vantagens e desvantagens entre a promoção do fim e a restrição aos direitos. Esse pensamento deve comandar a fase final da solução dos conflitos de direitos fundamentais após a análise da adequação e necessidade.

O raciocínio a ser seguido é de se a restrição a um direito fundamental pode ser justificada com base na relevância da prevalência do outro direito, deve-se comparar o direito fundamental restringido com o direito que prevalece, tratando assim dos efeitos positivos e negativos da restrição.

\footnotetext{
101 ALEXY, Robert. Teoria dos Direitos Fundamentais. Traduzido por Virgílio Afonso da Silva.
} São Paulo: Malheiros Editores, 2008. p. 591. 
O resultado do conflito deve ser colocado em uma balança; de um lado a importância da promoção do direito prevalente e do outro a gravidade da restrição ao direito considerado de menor peso e importância diante do caso. Dessa forma, a importância da promoção do direito prevalente deve justificar a restrição sofrida pelo outro direito envolvido.

Alexy considera que nessa etapa é realizado o verdadeiro sopesamento, que corresponde à otimização dos princípios colidentes. Sendo assim propõe uma análise em três passos:

“ No primeiro é avaliado o grau de não-satisfação ou afetação de um dos princípios. Depois, em um segundo passo, avalia-se a importância da satisfação do princípio colidente. Por fim, em um terceiro passo, deve ser avalisado se a importância da satisfação do princípio colidente justifica a afetação ou nãosatisfação do outro princípio." ${ }^{102}$

Ressalte-se que a atividade de determinação do bem jurídico de maior relevância deve levar em conta o peso concreto e o peso abstrato dos direitos em jogo. $\mathrm{O}$ peso concreto se caracteriza pela análise quantitativa do grau de restrição de um direito e da importância da promoção do outro direito enquanto o peso abstrato revela uma valoração da importância dos direitos envolvidos no ordenamento jurídico constitucional. Essas análises devem ser realizadas conjuntamente e irão determinar o peso dos direitos conflitantes.

Após essa determinação será analisada a relevância da restrição e a importância da prevalência, caracterizando assim, a análise da proporcionalidade em sentido estrito e criando uma "relação de precedência condicionada", ou seja, uma relação de precedência válida apenas para aquele caso concreto.

Esse raciocínio reflete a Lei de Sopesamento de Alexy, pela qual, “quanto maior for o grau de não-satisfação ou de afetação de um princípio, tanto maior terá que ser a importância da satisfação do outro."103

\footnotetext{
${ }^{102}$ ALEXY, Robert. Teoria dos Direitos Fundamentais. Traduzido por Virgílio Afonso da Silva. São Paulo: Malheiros Editores, 2008. p. 594.

${ }^{103}$ ALEXY, Robert. Teoria dos Direitos Fundamentais. Traduzido por Virgílio Afonso da Silva. São Paulo: Malheiros Editores, 2008. p. 593.
} 
Nesse sentido, vislumbra-se que, a ponderação deverá ser evitada se na análise da proporcionalidade em sentido estrito determinar-se que a restrição ao direito é mais grave que a importância da promoção do direito prevalente, no caso concreto.

Alguns autores ressaltam que se trata de exame extremamente complexo, pois a análise de vantagens e desvantagens pode tornar-se extremamente subjetiva ${ }^{104}$. Porém, Alexy rebate essa crítica, trazendo critérios de racionalidade, como já demostrado na análise de sua lei de sopesamento.

\subsection{A razoabilidade}

Assim como a proporcionalidade, a razoabilidade visa coibir o arbítrio e a irracionalidade na ponderação dos direitos fundamentais. Porém, diferentemente daquela, a razoabilidade não se baseia em análises de meios e fins.

Para sua qualificação são empregados diversos critérios, dentre os quais relevaremos os mais importantes a serem aplicados como limites ao método ponderativo.

Em primeiro lugar a razoabilidade é vista como equidade, demostrando a relação das normas gerais com o caso concreto. Nessa perspectiva, teremos a indicação da norma a ser aplicada ou se o caso analisado não se enquadra em uma norma geral. Essa análise vai apelar à lógica e à experiência comum harmonizando a norma geral com o caso individual.

Humberto Ávila determina que primeiramente deve ser considerado o que normalmente acontece, presumindo-se o ordinário, e não o extraordinário, na análise dos fatos. E que, em segundo lugar, na aplicação

\footnotetext{
${ }^{104}$ ÁVILA, Humberto. Teoria dos princípios: da definição à aplicação dos princípios jurídicos. 4. ed. rev. São Paulo: Malheiros, 2004. p. 124.
} 
da norma, devem ser consideradas as particularidades do caso concreto que não estejam retratadas na generalidade da norma. Sendo assim, ressalta que:

"Essas considerações levam à conclusão de que a razoabilidade serve de instrumento metodológico para demostrar que a incidência da norma é condição necessária mas não suficiente para sua aplicação. Para ser aplicável, o caso concreto deve adequar-se à generalização da norma geral. A razoabilidade atua na interpretação das regras gerais como decorrência do princípio da justiça." ${ }^{105}$

Nesse sentido, devemos utilizar a razoabilidade na ponderação para amoldar os direitos fundamentais em jogo ao caso concreto, na análise de seu peso.

Em segundo lugar a razoabilidade é empregada em sentido contrário de arbitrariedade, ou seja, determina que as restrições aos direitos fundamentais devem ser fundamentadas e motivadas por razões jurídicas relevantes.

Essa análise vai abranger a determinação de congruência entre as medidas adotadas e os critérios eleitos, ou seja, as restrições devem ser motivadas e essa motivação deve ser coerente com as medidas adotadas para a restrição aos direitos fundamentais.

Em terceiro lugar a razoabilidade é aplicada como dever de "consistência" e "coêrencia lógica" das decisões judiciais, consubstanciando o dever de os elementos da sentença não se contradizerem e de serem harmônicos com os valores do ordenamento jurídico.

Por fim, a razoabilidade é vista como uma noção de equivalência entre a medida adotada e o critério utilizado, ou seja, deve haver um equilíbrio entre o critério e a medida, entre as grandezas envolvidas no caso, trazendo assim uma noção que se afiniza à uma idéia de proporção.

Sendo assim, vemos que a razoabilidade serve em grande medida como limite à ponderação, pois estabelece a noção da análise das normas perante o caso concreto, considerando suas particularidades; a necessidade

\footnotetext{
${ }^{105}$ ÁVILA, Humberto. Teoria dos princípios: da definição à aplicação dos princípios jurídicos. 4. ed. rev. São Paulo: Malheiros, 2004. p. 103 a 106.
} 
de uma fundamentação coerente com o ordenamento jurídico na determinação dos pesos relativos dos direitos envolvidos; a necessidade de coerência, entre os direitos envolvidos e os valores do ordenamento jurídico, na decisão de prevalência; e a noção de equivalência e equilíbrio entre as medidas ponderativas adotadas.

\subsection{O núcleo essencial dos direitos fundamentais}

A consideração do núcleo essencial dos direitos fundamentais surge como mais um limite à atividade ponderativa, suscitando diversas discussões doutrinárias e ensejando a formação de diversas correntes para sua definição.

Essa garantia foi vista como uma forma de proteger os direitos fundamentais da atuação do aplicador, devendo este observá-la nas decisões ponderativas.

No Brasil, a garantia não foi positivada, mas pode ser considerada como consequência lógica do sistema constitucional e dos direitos fundamentais.

Sendo assim, entende-se que os direitos fundamentais não podem sofrer restrições tais que os tornem vazios de conteúdo. Nesse sentido, o conteúdo essencial seria o âmbito dos direitos que não poderia ser atingido pela atuação do intérprete.

Conclui-se assim que "não se pode admitir que conformações ou restrições possam chegar a esvaziar o sentido essencial dos direitos, que, afinal, formam o conjunto normativo de maior fundamentalidade, tanto axiológica, quanto normativa, nos sitemas jurídicos contemporâneos. Nesse sentido, o núcleo deve funcionar como um limite último de sentido, invulnerável, que sempre deverá ser respeitado. "106

Na doutrina não houve consenso sobre o tema, suscitando diversas discussões e o surgimento de variadas teorias sobre o núcleo essencial dos

106 BARCELlOS, Ana Paula. Ponderação, racionalidade e atividade jurisdicional. Rio de Janeiro: Renovar, 2005. p. 141. 
direitos. Para o presente trabalho, torna-se importante identificar apenas as teorias que se referem ao alcance do conteúdo essencial como limite, sendo essas a teoria absoluta ${ }^{107}$ e a teoria relativa ${ }^{108}$ do núcleo essencial.

A teoria absoluta, também conhecida como teoria do núcleo duro, sustenta que cada direito possui um núcleo que não pode, em nenhuma circunstância, sofrer restrições. Nas palavras de Jane Reis Gonçalves Pereira:

“(...) os que defendem essa perspectiva pressupõem que o direito fundamental pode ser desdobrado em duas partes: uma parte essencial, e, portanto, inviolável, e uma parte não essencial, que pode ser objeto de restrição. Pode-se explicar essa concepção a partir da imagem gráfica de círculos concêntricos. O círculo exterior é composto por faculdades periféricas ou acidentais, que podem ser sacrificadas para salvaguardar outros bens jurídicos, enquanto o círculo interior constitui um núcleo fixo e de contornos precisos, que não pode ser transposto sem que se incorra em inconstitucionalidade." 109

Para os seguidores dessa teoria o núcleo essencial de cada direito seria delimitado em abstrato, de forma que ao iniciar a atividade ponderativa o intérprete já conheceria os núcleos inatingíveis dos direitos que constituiriam assim, limites objetivos estabelecidos à sua atuação.

Diversas críticas são dirigidas à essa teoria. Primeiramente considera-se que essa teoria não admite situações de conflito que exijam a total restrição de um direito em favor de outro direito, por considerar que o núcleo essencial nunca poderá ser atingido, nem mesmo na situação de o direito em conflito ter um peso maior no caso concreto. Em segundo lugar critica-se a idéia de um núcleo abstratamente considerado, visto que este não existe e é de difícil definição, não tendo como o intérprete conhecê-lo antes da ponderação. Soma-se a isso a idéia de que os esforços na delimitação de um núcleo muitas vezes trazem resultados subjetivos e arbitrários e a dificuldade de separar o que é essencial do que é acidental em uma norma de direito fundamental. Por fim, critica-se a desvalorização dos elementos do direito que não estariam enquadrados no núcleo.

\footnotetext{
${ }^{107}$ Defendem essa teoria: J.J. Gomes Canotilho e José Carlos Vieira de Andrade.

${ }^{108}$ Robert Alexy apresenta-se como adepto dessa teoria.

109 PEREIRA, Jane Reis Gonçalves. Interpretação constitucional e direitos fundamentais: uma contribuição ao estudo das restrições aos direitos fundamentais na perspectiva da teoria dos princípios. Rio de Janeiro: Renovar, 2006. p. 373.
} 
Em sentido oposto, a teoria relativa, também conhecida como teoria do núcleo flexível, considera que apenas diante do caso concreto poderá ser visualizado o conteúdo essencial de um direito, ou seja, o núcleo não é abstrato e só será definido após uma ponderação que o indentificaria caso a caso. Nas palavras de Robert Alexy para a teoria relativa "o conteúdo essencial é aquilo que resta após o sopesamento". ${ }^{110}$

Nesse sentido poderíamos ter um direito fundamental totalmente comprimido em razão de outro que assumisse maior peso no caso concreto.

Os críticos também se insurgiram contra essa teoria, apontando diversas falhas relativas à sua adoção. Primeiramente consideram que essa teoria permitiria uma flexibilidade excessiva, podendo fazer dos direitos fundamentais conceitos completamente vazios. Em segundo lugar, questiona-se como o núcleo essencial poderia ser um limite à ponderação se é resultado desta, ou seja, a definição do núcleo é o resultado do método ponderativo, sendo contraditório considerar o núcleo essencial como limite à ponderação. Desta forma, haveria uma destruição da idéia de núcleo a ser respeitado, pois a noção acaba por se confundir com a idéia de ponderação. Por fim, defendem que o núcleo assim considerado seria reduzido à idéia de proporcionalidade tornando-se um mero apêndice do princípio.

Desta forma, vislumbra-se que ambas teorias apresentam falhas inconciliáveis e permenece a questão de qual posição deve o intérprete adotar na decisão ponderativa. As teorias relativas acabam por não estabelecer limite algum à atuação do intérprete e acabam reduzindo o conceito de núcleo essencial a quase nada, pois apenas após a ponderação poderiam ser definidos. Por outro lado as teorias absolutas, por mais que se apresentem como teoricamente interessantes, são praticamente de impossível concretização, pela dificuldade de se delinear de forma abstrata, o núcleo de todos os direitos fundamentais.

${ }^{110}$ ALEXY, Robert. Teoria dos Direitos Fundamentais. Traduzido por Virgílio Afonso da Silva. São Paulo: Malheiros Editores, 2008. p. 297. 
Jane Reis Gonçalves Pereira propõe a adoção de uma teoria relativa. Para a autora, o fato de o núcleo essencial não estar positivado na Constituição permitiria a adoção do conceito de forma diferenciada, desconsiderando os complicadores e vendo o núcleo essencial como um método jurídico argumentativo subsidiário no controle das restrições, ou seja, o núcleo essencial serviria de argumento para a motivação das decisões já previamente tomadas, sem contudo, influir nessas decisões.

\begin{abstract}
"Assim, conquanto a adoção da teoria relativa não permita atribuir à noção de conteúdo essencial o status de pauta autônoma na limitação da atividade legislativa, é viável reconhecer que essa noção pode atuar como instrumento argumentativo-retórico que joga a favor do direito no processo de ponderação. (...). Nessa perspectiva, pode-se identificar o conteúdo essencial com a noção de que, quanto mais severa for uma restrição a direito fundamental, menores as chances de a relevância da implementação de um princípio antagônico ser apta a justificá-la." "111
\end{abstract}

Para a autora, poderia ainda ser agregada outra regra argumentativa pela noção de núcleo essencial: no caso da ponderação, os direitos fundamentais teriam uma precedência prima facie ao entrarem em conflito com bens coletivos. Essa visão deriva do entendimento dos direitos fundamentais como trunfos contra a maioria, por preponderarem sobre metas coletivas. $^{112}$

Já Ana Paula de Barcellos traz outra proposta de adoção, que não considera nem as teorias absolutas nem as relativas, propugnando assim por uma outra solução na definição do núcleo essencial como limite à atuação do intérprete na atividade ponderativa:

“É perfeitamente possível e desejável, por meio da reflexão abstrata e/ou do estudo e tabulação dos precedentes judiciais, que a doutrina se ocupe de construir os sentidos próprios de cada direito, propondo parâmetros ou standarts específicos capazes de identificar o que deve ser considerado como prerrogativa essencial de cada direito, o que pode sofrer restrição, em que circunstâncias isso pode acontecer, dentre outros elementos necessários para a compreensão mais precisa dos direitos. Esse esforço hermenêutico contínuo não produzirá um núcleo duro nem permanente ou não-histórico, mas fornecerá um núcleo suficientemente consistente para funcionar como limite à atuação do intérprete e

\footnotetext{
${ }^{111}$ PEREIRA, Jane Reis Gonçalves. Interpretação constitucional e direitos fundamentais: uma contribuição ao estudo das restrições aos direitos fundamentais na perspectiva da teoria dos princípios. Rio de Janeiro: Renovar, 2006. p. 379 e 380.

${ }_{112}$ PEREIRA, Jane Reis Gonçalves. Interpretação constitucional e direitos fundamentais: uma contribuição ao estudo das restrições aos direitos fundamentais na perspectiva da teoria dos princípios. Rio de Janeiro: Renovar, 2006. p. 380 e 381.
} 
proteger em alguma medida os direitos fundamentais de ações arbitrárias e abusivas". 113

Outras teorias existem, que unem esforços na tentativa de identificarem teorias mistas do núcleo essencial. Porém o importante a ser considerado, independentemente da teoria que se adote, é que os direitos fundamentais não podem constituir normas vazias e que o intérprete, na realização da ponderação deve sempre considerar o núcleo essencial desses direitos, como limite à sua atuação, de forma a evitar o esvaziamento de seu conteúdo.

113 BARCELlOS, Ana Paula. Ponderação, racionalidade e atividade jurisdicional. Rio de Janeiro: Renovar, 2005. p. 145. 


\section{Conclusão}

Após diversas explicitações e respondidos os questionamentos iniciais resta reafirmar a importância da utilização do método ponderativo e que este se mostra como a técnica mais apta para a solução dos conflitos de direitos fundamentais.

Isso porque a ponderação diante dos conflitos de direitos fundamentais proporciona um resultado que melhor se conforma com a máxima da unidade da Constituição, pois deve sempre ser utilizada com vistas à harmonização dos direitos conflitantes e à busca da concordância prática.

Deve-se ressaltar que a técnica não está livre de subjetivismos e arbitrariedades e que para evitá-los todo e qualquer raciocínio ponderativo deve ser corretamente fundamentado e se balizar pelos limites do princípio da proporcionalidade, da razoabilidade e do núcleo essencial dos direitos fundamentais, que não deve ser violado. As decisões ponderativas não fundamentadas com base nesses limites muitas vezes escondem opções, crenças e interesses pessoais do exegeta que os faz prevalecer sem ao menos analisar as circunstâncias concretas. Assim, exige-se que para a utilização da técnica sejam impostos limites, os quais serão explicitados na fundamentação, demonstrando-se como e com base em quais premissas o exegeta chegou àquelas conclusões.

Apenas deste modo, com a imposição de limitações podemos reafirmar a importância do método e é exatamente por permitir esse controle racional de sua utilização que a ponderação se sobressai na comparação com outras técnicas que de igual modo buscam solucionar os conflitos de direitos fundamentais. Seja porque certas técnicas preconizam uma hierarquia de direitos constitucionais, o que conflita com nossa Carta que é compromissória e reflete uma sociedade plural, consagrando diversos e até mesmo opostos interesses em seu texto e viola o princípio da unidade da Constituição que iguala todos esses interesses, elevando-os à mesma 
categoria, com a mesma dignidade e importância. Seja porque a definição de categorias e limites imanentes dos direitos acaba por esconder raciocínios ponderativos que elegem definições e conceituações também permeadas pelo subjetivismo do intérprete, mas por acreditarem que esses raciocínios estão diretamente consagrados no texto constitucional não buscam métodos de justificação e acabam por permitir um subjetivismo e uma arbitrariedade ainda maiores.

Deste modo, conclui-se pela utilização do método ponderativo como técnica de melhor coerência e controle para os conflitos de direitos fundamentais, podendo sempre ser auxiliada, mas jamais suprida, pelos outros métodos apresentados.

Ilustrativamente podemos analisar a utilização do método ponderativo, tecendo considerações sobre as decisões do Supremo Tribunal Federal na análise de suas decisões de investigação de paternidade e da possibilidade de condução sob vara para a realização do exame de DNA ${ }^{114}$.

O primeiro caso a ser analisado é considerado o leading case sobre o tema e realizou a apreciação em sede de habeas corpus da legalidade da determinação de condução sob vara para a realização de exame de DNA. ${ }^{115}$

Alegou o impetrante que tal determinação violaria seu direito fundamental à integridade física e à intimidade consagrados no $\operatorname{art} .5^{\circ}, \mathrm{X}$, de nossa Carta Magna e também que não haveria qualquer lei que o obrigasse a submeter-se ao exame, violando-se também o art. $5^{\circ}$, II, da Constituição Federal. Essa alegação prevaleceu por maiorias de votos e o habeas corpus foi deferido, consagrando assim a ilegalidade da decisão que determinava a condução sob vara no caso do não comparecimento para a realização de exame de DNA.

Os Ministros que votaram no sentido vencedor foram guiados pelo ilustre voto do Ministro Marco Aurélio que em suas conclusões realçou a

\footnotetext{
${ }^{114}$ Duas são as decisões de maior importância na análise do caso e mostraremos suas diferenças essenciais; são elas: STF, HC 71373-4/RS, Rel. Ministro Francisco Rezek, Brasília, 10 nov. 1994 e STF, HC 76060-4/ SC, Rel. Ministro Sepúlveda Pertence, Brasília, 31 mar. 1998.

${ }^{115}$ STF, HC 71373-4/RS, Rel. Ministro Francisco Rezek, Brasília, 10 nov. 1994. Ver Anexo I.
} 
evidente violação dos dispositivos constitucionais enunciados ao determinar que:

“É irrecusável o direito do Paciente de não ser conduzido, mediante coerção física, ao laboratório. É irrecusável o direito do Paciente de não permitir que se lhe retire, das próprias veias, porção de sangue, por menor que seja, para a realização do exame. A recusa do paciente há de ser resolvida não no campo da violência física, da ofensa à dignidade humana, mas no plano instrumental, reservado ao Juízo competente - ou seja, o da investigação de paternidade - a análise cabível e a definição, sopesadas a prova coligida e a recusa do réu."

Assim, concluiu o eminente Ministro que a solução para o caso estaria consagrada no Código de Processo Civil e que a recusa de submissão ao exame poderia ser interpretada como uma presunção de paternidade.

Vencidos ficaram os Ministros Ilmar Galvão, Carlos Velloso e Sepúlveda Pertence que alinharam seus entendimentos ao brilhante voto do Ministro Relator ao entender que se tratava, na hipótese, de uma colisão de direitos fundamentais. De um lado teríamos o direito à integridade física do impetrante e de outro o direito à dignidade de uma criança que busca conhecer sua real identidade. Assim, concordaram os Ministros no sentido de determinar a prevalência do direito da criança de conhecer sua real identidade, considerando que o direito à integridade física não é absoluto e restaria minimamente ofendido no caso em tela.

Ademais ressaltou que a presunção de paternidade solucionaria o problema do ponto de vista apenas material, posto que a criança teria direito à uma identidade real e não apenas presumida, estando esta resolvida de modo insatisfatório.

Assim reconheceu que por mais que a condução sob vara viole direito fundamental à intangibilidade corporal, este não é absoluto e que deve ceder espaço à busca da verdade real à proteção constitucional da criança garantindo sua dignidade e seu direito à identidade familiar.

Diante do caso concreto, data venia, adoto posição consentânea aos votos vencidos por entender que há no caso um evidente conflito dos direitos fundamentais à integridade física do impetrante e à real identidade e 
dignidade da criança, que busca conhecer seu verdadeiro pai. Assim, diante da colisão de direitos, penso que deva ser adotado raciocínio ponderativo, utilizando-se das premissas expostas para justificar assim a obrigatoriedade de realização do exame.

Trata-se no caso de um direito da criança a reconhecer sua identidade familiar, seu genitor, e esse direito não deve ser visto apenas do ponto de vista material, do dever dos pais de sustentar seus filhos, mas também do ponto de vista moral, do direito da criança à sua dignidade, ao reconhecimento de sua origem. A presunção de paternidade permite uma solução patrimonial do caso, mas jamais permitirá uma solução moral, restando para sempre a dúvida de sua real identidade. De outro lado, o exame de DNA, pela certeza proporcionada, permite uma solução patrimonial e moral, totalmente satisfativa dos direitos da criança, tão protegidos constitucionalmente e que devem ser privilegiados diante de uma violação reduzida da integridade física do suposto pai.

Utilizando-se da lei de sopesamento de Alexy poderíamos atribuir graus (leve, médio e grave) às restrições e à importância da satisfação dos direitos envolvidos. Assim, teríamos uma restrição leve à integridade física posto que o exame não necessita sequer de coleta sanguínea, podendo ser realizado através de material bucal ou fios de cabelo. De outro lado, teríamos uma importância de satisfação grave, visto que a mera presunção de paternidade não garante à criança seu direito pleno à identidade e que sua dignidade e até sua personalidade resta afetada pelo não reconhecimento de sua identidade familiar. Teríamos então uma relação de precedência condicionada, na qual a restrição mínima à integridade física estaria justificada pela impossibilidade de ser garantido por outros meios o direito da criança à sua identidade real.

Não caberia, nesse caso, a alegação de violação da proporcionalidade em seu subprincípio da necessidade, pois a presunção por mais que determine um pai para a criança não traduz o mesmo resultado de proporcionar uma identidade real, que só pode ser determinada de forma 
indubitável pela realização do exame de DNA. Deste modo, a consideração da presunção é menos gravosa, mas não é igualmente eficaz na proteção dos direitos da criança, devendo ser desconsiderada.

Entendo então, que diante da utilização da ponderação pautada por seus limites, a restrição à integridade física do suposto pai é justificada com base na relevância da prevalência do direito da criança de conhecer sua real identidade, afinizando meu entendimento com o expresso nos votos vencidos do referido acórdão.

Decisão diferente foi a adotada pelo STF no HC 76060-4/ SC ${ }^{116}$, diante do qual, decidiu-se por unanimidade pela ilegalidade da obrigatoriedade de realização do exame de DNA.

Trata-se de caso no qual terceiro contesta a paternidade presumida de uma criança. Ocorre que o terceiro, buscando comprovar sua paternidade biológica, solicita a obrigatoriedade do pai presumido, posto ter sido o filho concebido na constância de casamento, realizar exame laboratorial de DNA.

Diante do caso, o Ministro Relator Sepúlveda Pertence decidiu de forma contrária ao seu entendimento apresentado no HC 71373-4/RS, decisão esta que foi seguida por todos os outros Ministros e com a qual apresento minha afinidade por se tratar de caso extremamente diferente do anteriormente considerado.

Asseverou o ilustre Ministro Relator que, apesar de suas considerações anteriores sobre o direito da criança à sua real identidade e sobre a prevalência deste sobre a integridade física na realização de exame de DNA, o caso apresentado sugeria relevo totalmente diferente por estar sendo exigida prova de reforço do pai presumido, ora paciente, por um terceiro que se declara pai biológico da criança. Assim, ressalta que não pode ser o paciente obrigado a produzir prova de reforço contra a presunção de que é titular e que a paternidade biológica poderia ser comprovada apenas com a realização de exame de DNA da criança e do terceiro que se

\footnotetext{
${ }^{116}$ STF, HC 76060-4/ SC, Rel. Ministro Sepúlveda Pertence, Brasília, 31 mar. 1998. Ver Anexo II.
} 
diz pai. Ademais, ressalta que a ilegalidade do exame não é certamente pela colheita mínima de material e ofensa irrisória à integridade física, mas sim pela ofensa à dignidade pessoal do pai pressumido em se submeter ao exame.

Diante desse caso, percebemos mais uma vez a importância da ponderação de interesses e também como as circustâncias do caso podem influenciar na formação de opinião do intérprete. Isso porque o caso apresentado traz à tona circunstâncias completamente diferentes da anteriormente apresentada e assim levou os Ministros a se unirem no entendimento de ilegalidade da coerção física do paciente para a realização do exame. Essa decisão se sutenta sobretudo pela nítida violação ao princípio da proporcionalidade e seu subprincípio da necessidade, pois o mesmo resultado pode ser obtido pela realização de meio menos gravoso, qual seja, pelo realização de exame de DNA entre o suposto pai biológico e a criança, não havendo assim, a necessidade de atingir a integridade física do paciente para ser demostrada a paternidade biológica da criança.

Deste modo, poderíamos considerar a restrição como grave por existirem outros meios de se comprovar com a mesma certeza a paternidade biológica sem envolver o pai presumido da criança e sem gerar qualquer constrangimento à sua dignidade pessoal, não se justificando essa intervenção.

Por fim, insta ressaltar, diante da análise dos casos, a grande importância da análise da colisão de direitos fundamentais diante das circunstâncias do caso concreto e a iminente necessidade de o raciocínio ponderativo ser permeado por limites e ter uma fundamentação que permita uma análise do raciocínio desenvolvido e do respeito aos limites a ela inerentes. 


\section{Bibliografia}

ALEXY, Robert. Teoria dos Direitos Fundamentais. Traduzido por Virgílio Afonso da Silva. São Paulo: Malheiros Editores, 2008. 670 p.

Direitos fundamentais, ponderação e racionalidade. Revista de Direito Privado, São Paulo, v. 6 , n.24, out./dez. 2005. p. 334-344.

. Colisão de direitos fundamentais e realização de direitos fundamentais no Estado de direito democrático. Revista de Direito Administrativo, Rio de Janeiro , n.217, jul./set. 1999. p. 67-79.

ANDRADE, J. C. Vieira. Direitos Fundamentais na Constituição Portuguesa de 1976. $3^{\text {a }}$ ed.. Almedina, 2004.

ÁVILA, Humberto. Teoria dos princípios: da definição à aplicação dos princípios jurídicos. 4. ed. rev. São Paulo: Malheiros, 2004. 138 p.

BARCELlOS, Ana Paula. Ponderação, racionalidade e atividade jurisdicional. Rio de Janeiro: Renovar, 2005. 334 p.

A eficácia jurídica dos princípios constitucionais: o princípio da dignidade da pessoa humana. 2. ed. Rio de Janeiro: Renovar, 2008.

A Nova interpretação constitucional: ponderação, direitos fundamentais $e$ relações privadas. 3. ed.r. Rio de Janeiro: Renovar, 2008. 419 p.

BARROSO, Luis Roberto. Interpretação e aplicação da constituição: fundamentos de uma dogmática constitucional transformadora. 6. ed. rev., atual. e ampl. São Paulo: Saraiva, 2004. 427 p.

O Direito Constitucional e a Efetividade de suas Normas: Limites e Possibilidades da Constituição Brasileira. $9^{a}$ ed. Atualizada. Renovar, 2009. 345 p. BOBBIO, Norberto. Teoria do Ordenamento Jurídico. 5.ed. Brasília. DF.: UnB, 1994. 184p. 
BUECHELE, Paulo Arminio Tavares. O princípio da proporcionalidade e a interpretação da constituição. Rio de Janeiro: Renovar, 1999. 194 p.

CADEMARTORI, Luiz Henrique Urquhart. Hermenêutica principiológica e colisão de direitos fundamentais: as teorias de Aléxy e Dworkin e os aportes de Habermas. Novos Estudos Jurídicos, Itajaí , v.11,n.1, p. 135-141, jan./jun. 2006.

CANOtilho, J. J. Gomes. Direito Constitucional e Teoria da Constituição. $7^{\mathrm{a}}$ ed. Coimbra: Almedina, 2003. 1522 p.

COMPARATO, Fábio Konder. A afirmação histórica dos direitos humanos. $5^{\mathrm{a}}$ ed.. Saraiva, 2007. 488 p.

CRUZ, Paulo Márcio; GOMES, Rogério Zuel. Princípios constitucionais e direitos fundamentais: contribuições ao debate. Curitiba: Juruá, 2006. 271 p.

ESPÍNDOLA, Ruy Samuel. Conceito de princípios constitucionais: elemento teóricos para uma formulação dogmática constitucionalmente adequada. $2^{\mathrm{a}}$ ed. rev., atual. e ampliada. São Paulo: Editora Revista dos Tribunais, 2002.

FARIA, Miguel José. Direitos Fundamentais e Direitos do Homem. vol. I. 3 ed. Lisboa: Instituto Superior de Ciências Políticas e Segurança Interna, 2001.

FARIAS, Edilson Pereira de. Colisão de direitos: a honra, a intimidade, a vida privada e a imagem versus a liberdade de expressão e informação. 2. ed. ra. Porto Alegre: Sergio Antonio Fabris, 2000. 208 p.

FERRACIOLI, Maria da Graça Mello; GIRARDI, Maria Fernanda do Amaral Pereira Gugelmin. A inter-relação entre princípios jurídicos, legitimidade e direitos fundamentais: reflexos a partir da visão de Robert Alexy. Novos Estudos Jurídicos, Itajaí, v.10, n.2, p. 399-416, jul./dez. 2005.

FIORAVANTI, Maurizio. Los derechos fundamentales: apuntes de historia de las constituciones. 4. ed. Madrid: Editorial Trotta, 2003. 165 p.

GUERRA FILHO, Willis Santiago. Direitos Fundamentais, processo e princípio da proporcionalidade. In: WILLIS SANTIAGO, Guerra Filho (Coord.) Dos 
Direitos Humanos aos Direitos Fundamentais. Porto Alegre: Ed. Livraria do Advogado, 1997. P. 11-29.

GUERRA, Sidney. Hermenêutica, ponderação e colisão de direitos fundamentais. Rio de Janeiro: Lumen Juris, 2007. 177 p.

HESSE, Konrad. Trad. Gilmar Ferreira Mendes. A Força Normativa da Constituição. Porto Alegre: Sergio Antonio Fabris Editor, 1991. 40 p.

MATTOS, Sayonara Gonçalves da Silva; CITTADINO, Gisele. Normas constitucionais e colisão de direitos fundamentais : a quebra do sigilo bancário pela autoridade fiscal. Rio de Janeiro, 2004. 118 p. Dissertação (Mestrado) Pontifícia Universidade Católica do Rio de Janeiro, Departamento de Direito.

MEDEIROS, Rui. O Estado de direitos fundamentais português: alcance, limites e desafios. In: Anuário Português de Direito Constitucional, II, 2002, p. 23-43.

MENDES, Gilmar Ferreira. Hermenêutica constitucional e direitos fundamentais. Brasília: Brasília Jurídica, 2002. 322p.

MORAES, Alexandre de. Direitos Humanos Fundamentais: teoria geral. 8 Ed. Rio de Janeiro: Atlas, 2007. 335 p.

NOVAIS, Jorge Reis. Direitos Fundamentais: Trunfos Contra a Maioria. Coimbra, 2006.

PEIXINHO, Manoel Messias; MAIA, Antonio Carlos Cavalcanti. Teorias $e$ métodos de interpretação dos direitos fundamentais. Rio de Janeiro, 2004. 406 p. Tese (Doutorado) - Pontifícia Universidade Católica do Rio de Janeiro, Departamento de Direito.

PEREIRA, Jane Reis Gonçalves. Interpretação Constitucional e Direitos Fundamentais. Renovar, 2006. 546 p.

QUEIROZ, Cristina M. M.. Direitos Fundamentais (teoria geral). Teses e Monografias 4. Faculdade de Direito da Universidade do Porto. Coimbra, 2002. P. 200-265. 
REALE, Miguel. Lições Preliminares de Direito. $27^{\mathrm{a}}$ ed. ajustada ao novo Código Civil. São Paulo: Saraiva, 2005. 391 p.

SABINO, Paulo Ricardo Ferrari; MAIA, Antonio Cavalcanti. $O$ modelo de aplicação de princípios jurídicos de Alexy: da teoria econômica ao direito da concorrência. Rio de Janeiro, 2005. 77 p. Dissertação (Mestrado em Direito)Pontifícia Universidade Católica do Rio de Janeiro.

SARMENTO, Daniel. A ponderação de interesses na Constituição Federal. Rio de Janeiro: Lúmen Júris, 2002. 219 p.

STEINMETZ, Wilson Antonio. Colisão de direitos fundamentais e principio da proporcionalidade. Porto Alegre, Livr. do Advogado, 2001. 223 p.

TORRES, Ricardo Lobo. Teoria dos direitos fundamentais. 2. ed. rev. e atual Rio de Janeiro: Renovar, 2001. 454 p. 


\section{Anexo I}

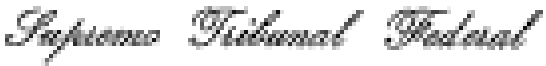

SERVICO DE JURISPRUDBNCIA

D.J. 22.11 .96

BMRNTARIO NO 18 \& 51 = 0 - 2
397

TRIBUNRL PLBNO

$10 / 11 / 94$

\section{HABEAS CORPUS NE Z1373-4 BTO GRANDE DO SUL.}

PACIBNTB : JOSE MNTONIO DOMZS PIMEIEIRO MACHADO

IMPETEMUTE I JOSE ANTOWIO DONSB PTMHEIRO MACHADO

COATOR : TRIBUTAL DE JUSTIÇA DO BSTADO DO RIO GRANDB DO SUL

INVESTICAÇKO DE PATERATDADE - EXAME DNA -

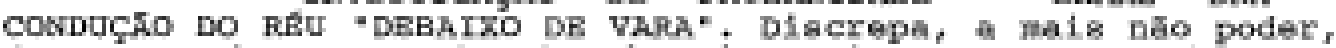
de garantias constitucionals inplicitas e explicitas preservaç̄o de dignidede humana, da intinidede, da intangibilidede do corpo humano, do império da lei e da inexecuģa especifica e direta de obrigaçắo de fazer provimento judicial que, en açä́o civil de inveatigaçăo de paternidade, implique determinaçăo no rentido de o rón aer conduzido ao laboratorio, "debaixo de vara", para coleta do naterial tndiepengavel a feltura do examo DNA. A recusa resolve-se no plano juridico-inatrumental, consideradas a dognatica, a doutrina e a jurisprudencia, no que voltadas to deslinde das questóes lifgadas a prova dos faton.

\section{$A \underline{\mathrm{C}} \mathrm{B} \underline{\mathrm{D}} \mathrm{Q}$}

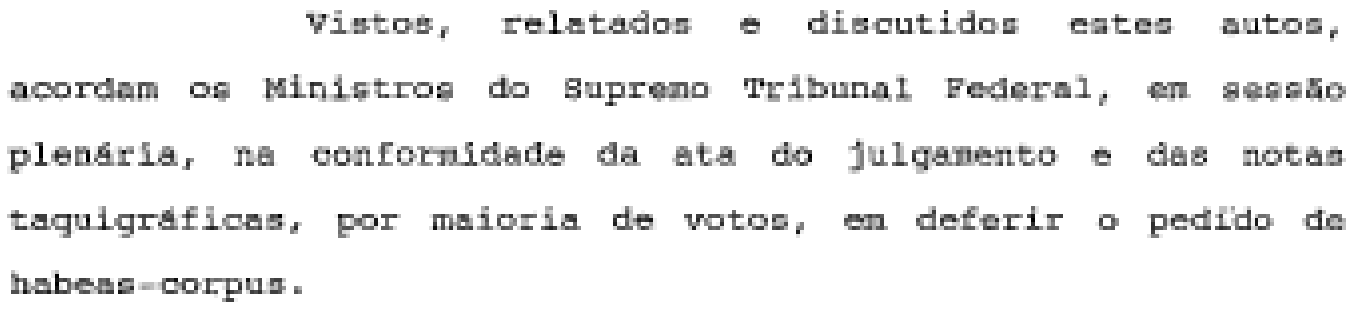

Brasilia, 10 de novenbro de 1994.
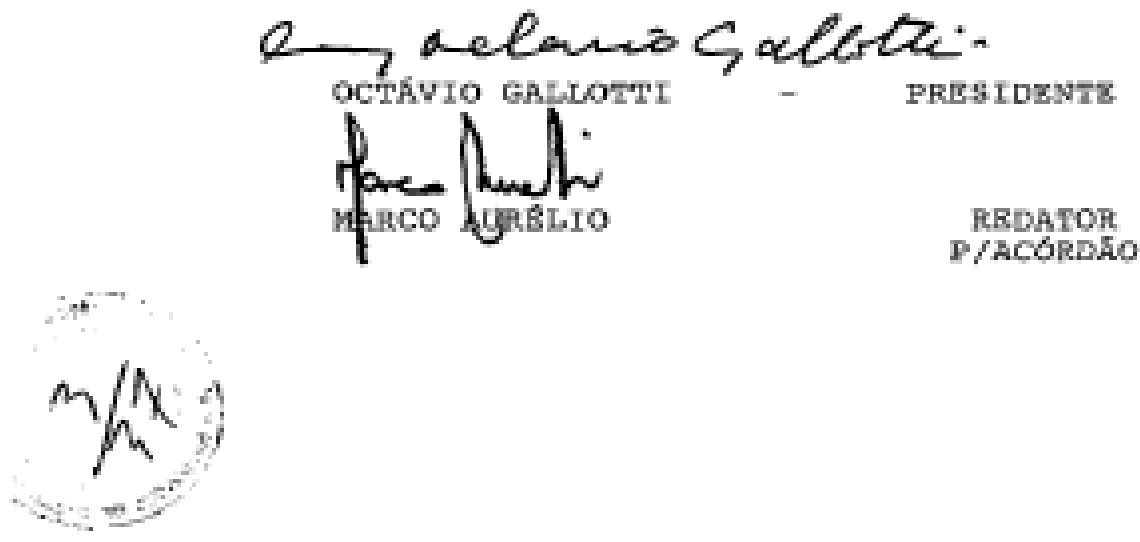
14.1 .84

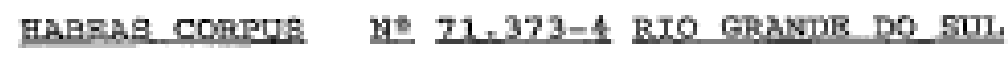

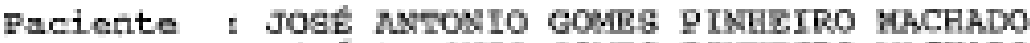
Impetrante. JOBE nMTOHIO GOMEB PIMUETRO MACHADO

Coator \# TRIETNAI, DE JUETICA DO FBTADO DO FIO GRANDE DO BUL

\section{B E I $\mathrm{E}$ T $\mathrm{E}$ I $\mathrm{B}$}

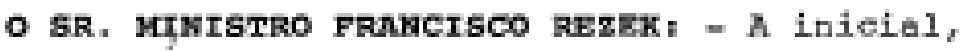
que axpoe on proprtedade a questso juridloa, toi redigida pelo proprio paciente, Joge Mntonio Goneg Pinhefro Mabhado, e diz

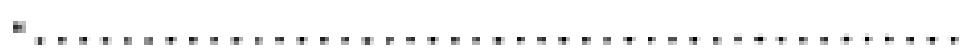

Contra o Impetrante trarita, na Bequnda Vare

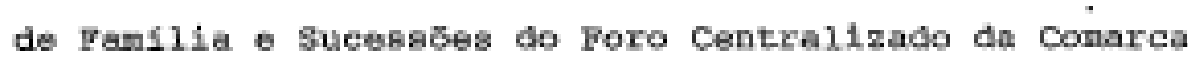
de Porto Rleqre, ume agäo de investigegás de paternidede promovida por ThAIs hapgues Rosh a LIVIA MArques Rogh, ghnese nasoides a 19 de novembro de 1990, filhas de Helolas Maria Marques Bosa.

Ordehada prove perielni eppoifica, modiante andige de grupos senglineos a outres Investigagogr, o Impotrante intimado comanicou que nao se bubmeteria a exanes, o que tol acolto pela Dra. Julza a 20/05/92. reconhecendo que a parte nao arets obrigada b realizactio da prova, mas sua negativa rerd analisado de deords son o roatante da prova.

Depols, pntes de aer cogclulda a adiencia, a Dra, Juina adotou qutra alugar, para coafir o Impetrante a eubmbtex-se abs exanes perialato 
oogltador no infalo. A ditims daclaso (de 27/11/92) ter eute teor que interebea, sendo do Impetiante os aublinhamentor:

"Tendo em vieta nova jurieprudendia que aneça a denpontar eobre o tema da recuan en fazer o okens para comprovacto da pateraidade, reprenentade pelo agravo de inetrumento a" SeBo21022, da 4" canara civel do E. TJRGB, Rev de Jurlap. a 147, págs. 301 a 304 r revieo minha posiģo de 11 . 81 .

No presente caso entho en Jogo interesess de duas menores. Outrosain, pelo que enta nos autor, una das partes eath Raltando con a verdade $e$ o exame dirine dovida estabelecondo, praticamente en definitivo, con quen esta a verdade, desmancarando-me ou a oportuniata ou o que tenta extrix-ae da responeabilidade an patermidade.

Mag hil motivo para que o rab be negue so exame, a menos que esteja con reselo do Iegultado-Hoja, con a avango-das poaquinas gentelcae, 6 inconcebivel que noo seja feito tal exame neste tipo de açión.

Aseim, determino a realizacaso do exane, a oer Iodizado pelo Dr = Jobim, ji

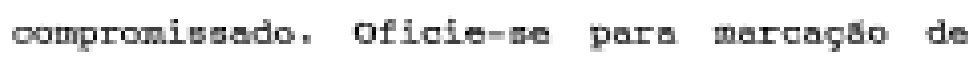
data- Deverd o ran comparecer, agalm que intimado, wab pena de conducho oph vara, als que, no, caso, ael orpo 6 "objeto de $\mathrm{B}^{2}$ 
HC $71.373=4$ RS

$$
\begin{aligned}
& \text { direitos', nâ sendo cebivel invocer } \\
& \text { 'direito personalfeeino de dieponibilidade } \\
& \text { do proprio corpo'. }
\end{aligned}
$$

A determinaçōo nåo tol logo executada, en virtude de egravo de instrumento interposto pelo Impetrante, com efeito sumpenaivo concedido pela meama Dra. Juiza.

Solugto no agravor - Ao julgar o agravo de Insturento aludico, a Oitava Camera civel do TJRB, pela raforia de dois votos contra un, manteve a decisăo de prineiro grau, havendo disposiçōes expresses e nitidas. No julganento do agravo a 4 de novenbro de 1993, coneignou-se Een resealvas que a oitava Camara Crvel do Tribunal de Jugtige do Estado do Rio Grande do sul, por maioria, acorda cm negar provinento no agravo, vencido $\circ \mathrm{Km}$. Dr. Glorgis, que dava provinento.

Wo julgamento dos embargos de deelaraçto a 16 de dezembro de 1993, oferecidos pelo impetrante em face dan omisebes do acordato, a decisto os acolheu, exprimindo os fundamentos e mantendo o dispositivo, para, aanados os pontos omiasos, confirmar, quanto ao mais, tudo $\circ$ que se contén naquele aresto (o acordăo embargado) .

Disno resulta que a deciaso de primelro grau restou assumida ne segunda instancia, pelas explfeitaģöes da Oitava camara civel do TJRs, no julgamento composto, șncluatve na parte que inpōe o 
HC 71.273-4 BS

eompresimanto do Impatranto para aubmater-ne a axame

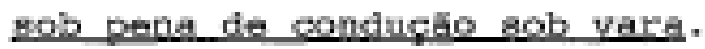

9 Inpetrante tnterpos recureo apecial e

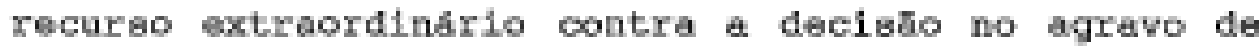

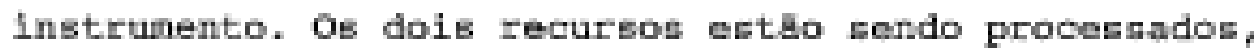

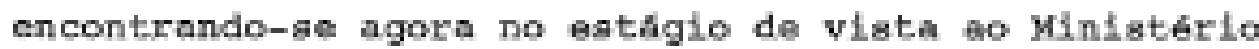
Pablicos.

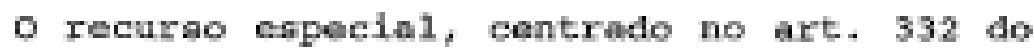
caligo de proseses civil, austanta que a deciedo recorrida contrarlou ans diapoaltho a divergiu da interpretagas a ele dada pela Begunda canara civol do

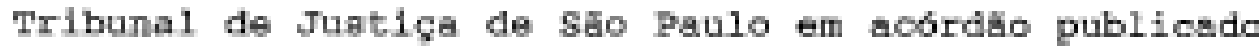
[RTIJBP, LEx, $111 / 350-353$ ).

0 recurao extraordinste axghmenta que a doatano racorrida eontrariou os ineisob $I I$ e $x$ do at. 5* de constituigab de Repbblioa, ecarinador na gua eigrificacko dirata.

Rager recuraos axcopolonelis näo têm efatto subpensivo, eono $f$ ourial, de modo que ae engotou

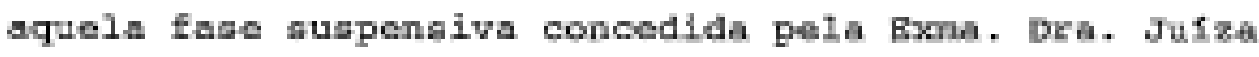
de privelro grau b eludida na parte final do iten $z_{4}$ acima.

Comunicada palo Tribunal a Julzo de origem. - aolugho do agrawo de instumento a marcado polo perito o dia 14 de abril de 1994, as 9 horas, no Hospltal da clinicas de porto Alegre, para ranilzar o enane, a Dra, Julza logo reativou aquela prinitiva doterulnapho, de 27/11/92, explieltou 1 eto ma folha $\mathrm{d}^{4}$ 


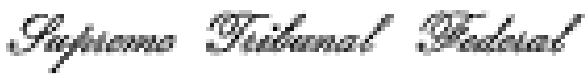

HC 71.373-4 ES

402

207 do processo:

'Intime-se o rfu, sob pena de condupto nob varal Urgenoia, elig que próxima a data marcada para o exame. Int. Em 17/09/94." (Aaginature)

E evidente que agora o Jufro de primeliro grau ja nao opera por iniclativa proprie, mas executa A decisăo que foi asaumida poln oltava camara civel do TURB.

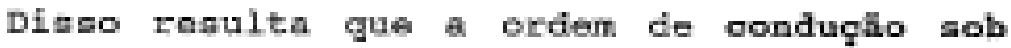
vara ab reputa eonandeda pela aludida camara crvel, de

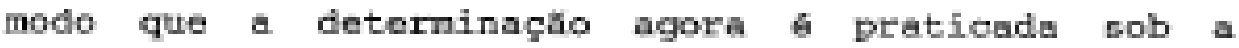
responabilidnde daquele orgto fradiondrio do Tribunal de Juetiga do Rio orande do sul, eon reflexo Irrecundwel aA definiço da competencie para apreclar o ato judicial.

o quadro presente to caradterixa pela ameaça que vigoru contre $\theta$ Impetrante de ser condurido aob vare, pare suhneter-es a some, contre aua vontade, embora batejan am durbo duas nanifestaçoon de desconformidade que poden alterar a determinaçăo aesumida pela be Clmara clvel do pura.

Oe ator judictala ato nitidos, con a eepecificagaso expresas, impondo que o Impetrante compareça on local, diw e hora indicados, pois do contrario serd oonduzido sob vara.

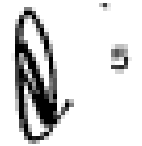


HC $71.373=4$ Res

\begin{abstract}
A orden antecipadamente progranada constitui ameaça de concino, porqua a conduçuo ropreachtaru violenoia oontra a liberdade de lonomogio do Impetrante, cuja recuas fol expresanente manifoatada nos autos, ha osden dada ha llegalidade 2 abueo de poder, parque ae executa nedida regtritiva de liberdade antes de exaurir-se o julgamento da nateria, pela buncitaç5o non tecureon excopetonale.
\end{abstract}

Importa blextar para o inusitado da determineçio, porque no ordenemento proceasual brasileiro a condugbo da parte ab an concebe com o sentido de pristo.

o nă comparocimento da parte pode acarmetar sangoes esperifices, mas nos atoriza que ela ofa conduzlda debalxo do vara, Bm naterda penal o cPP 6 catequrfoo: o acueado eafre og efeltos da revelia te, citado inicialmente ou intimado depola, delvar de oompareaer agi motivo justifieado (art. 366$)$ p ao

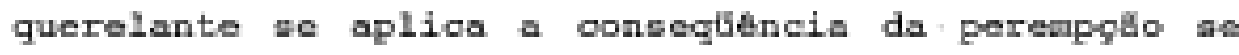
ele delsar de comparecar, fem mottwo juatificado, a Tuw lquer ato to processo if que deva estat ptegente (art. 60. III) En materta aivil a parte que intimada

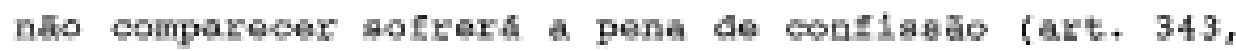
9 37, do GPC). Mas en nentur coso esta autorlzada a conduço onativa da partes.

$$
\text { Em faco da controveraia reconhacida, a }
$$




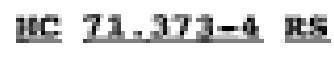

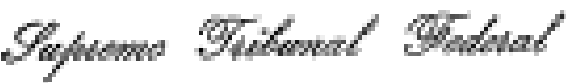

404

problen axlge solucho onputivel on o obdenemento jurldioo vigente.

vum polo, na nateria suecitada, nom pronuncimanto conhecido do Bupreno Tribunal Federni, vigoran preceltos que Eermitem a recusa de, na aço de que be trata, o investigado fornecer seu corpo ao exane. No art. 5 da conatituliclo Federal axilatem an matrizes male eflolentes: - o inciso 1 I refima a tradigio de que nlnguen d obrigado a fazer ou delyar de faxer alguma colsa sentio em virtude de les, do modo que, por nas existir disposigato legal impondo a abbitando, o inveatigado nio pode ber conatrangido a aujeltar-ae a ela; - o incleo $x$ coneagton que sio infiolfiveis a intinidade e a Tida prirada, de sorte que aqui eata radicada a raxă impeditiva do violar epear purticularidades, medlante exames forçados 'que atingen a intimidade a a privacidade. Mo art. 332 do codigo de procese clvil as impede, a contrarto, o uso de mefor ilegftimos, devendo asein considerat-be os que estro vedados ha via conetitucional.

Noutro polo, no entido irrevereivel, realizar o exama no presente eatugio, quando sa irreaignaçoes poden no seu desfecho deterninar a possiblidade de recuga, constitul risco que deve eer avitado pelo Poder Judieifio. Efetivamente, se un dog reeuraoa oxcopoionaia reconheoer a legltimidade da recuas, o exame relto mediante violendia d incompativel com toda a setrutura des gatantia contempladan no art. It da Lei Fundamental, porgue,

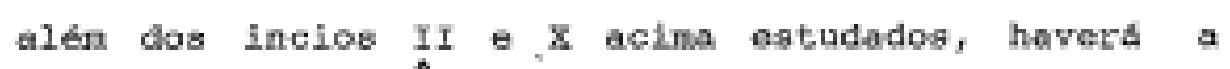
$\mathrm{d}^{7}$ 


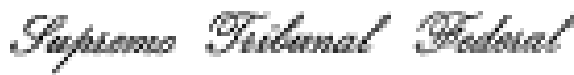

HC $71.373-4$ B.8

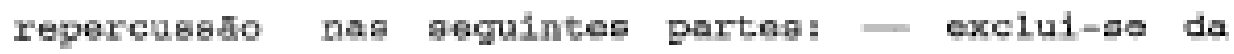
apreoiaga do poder Judioiarlo a ansesen a dreteo, con infregaro a incieo xxy, - priva-ge da liberdade a

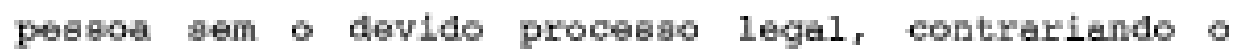
Inciao ITV; - pratica-as violenda equivalente a prisāo sem oonfigurapto delituosa, afrontando o inciso III

Wo conjunto a execuga de orden decortente do julgamento tradux o risoo de violagío grawo das garantiag ongtitueionais coneolidades.

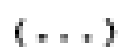

En vista do programa antingiado, oon $a$ Intimapto para o comprecianto no dia duatorze do oorrente ins, ene a edvertenoia da pena de condugho sob vara, deadobra-ae a pretenano.

Limfinarmente, ent carater de wrghnala para evitar que ae promova a realizmoto progranada, 4 necesedio subtar as efeitos de determinacko resultante do aobida no agravo de ingtrunento, ate que seja Julftolo o habeas eotpug.

En definitivo, inports que a determingla fique suspansa ats que abjan julgados os recuras excepcionala 1 terpoator pelo Impetrante an relapto an memo acóndä.

Pelo exporto, o Inpetrante pede:

a) - que vosea Exoeltacis ce digne de ordenar que deda distribuldo tete habods oorpus;

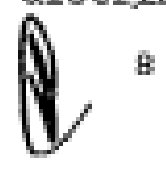




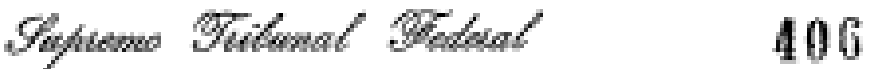

uc 21.373-4 12s

b) - que o sxcelentissino Kinistro Reletor determine en carater lininax a austaçio dos eteiton da decisāo decorxente do feito 593208228 (agravo de instrumento) e 593155963 (enbargos de declaraçso no mesno agrevo) do Tribunal de Justiça do Rio Grande do Sul, dectaro de que resulta a order de o Impetrente comparecer no Hospital de Clinicas de Porto Alegre sob pena de ger condugido, no dia 14 de abril de 1994, às 8 horea;

o) - gue, solioitadas e prestadas aa informaçöes, com observancia dos termos proprios, e praticados os demais ator adequados ao proceseo, 0 Supremo Tribunal. Pederal, pelo 6rgalo competente, acolha o pedido de habeas corpus ea favor do Impetrante, para suspender a mesma orden ate que seja conhecido o resultado final dos recursos eapecial e extraordinario interpostog em releça mo acordāo do alualdo feito (de nameros 593108228 e 593155963 do TURB)." (fls. 03/07).

Deteri a 1ininar, mediante despacho,

Aszencio:

"A deciato do juizo alngular, mantida pelo Tribunel de Juatige, gue determinow o corpereoimento do paciente, sob pena de conduço forç̧ada, para a realizeço do exame de conprovaçăo de paternidade, diz ela propria de sua inspiraçăo em uma jurisprudencia ainda incipiente quanto as consegilencias da resigtencie. 
HC $71.373-4$ BS

Asaim, a vieta das caracterfeticas incomuns do caso, a atento ao fato de estar o exane maxcado para o proximo dia 14, concedo a lininar, para que o peciente naso sefa compelido a faze-1o, ate que o supreno Tribunal pederal decida sobre o pedido de habeas eorpus.

Solicitem-ge informaçōes, e, đepoin, abra-ae vieta A Procuradoria-Geral de Replblice." (F18, 170)

- Subprocurador-Geral da Repablica clátudio Lenos Fonteles, manifestando-se em nome do Kinisterio Pablico Federa1, optna pelo indeferimento do pedido.

B o relatorio. 
o SR. MTNISTRO FRanctsco RIgEK (Relator); Obeervo, de infoio, eer de inteira logica, eabora năo cotidiano, que do foro csvel promene constranginento ilegal corrigivel mediante habeas corpus. No caso en exame, culda-ge de saber se o investigado, na agto do verificağto do paternidade, pode ser forcado, a vinta de aua recuar, a ge subneter a certa prova pericial, o exane hematologico, o tema ganha relevo seja por caura do advento, no canpo da nedicina legal, do exame de deterninaço de paternidade pelo nétodo do DNA (deido denoxirribonucleico), seja a onta da arescente preocupaçio do legialador e dos tribunais con os asreitos da crlança e do aclolescente.

- professor Calo Nario da silva Péreira ponderou hs anos, en obra sobre o tema, que to progresso constante da clencla pode conduzix a fixacrio do tipo sangaineo em termos têo precisos, que venha a constituir elemento de conviç̧oso definitiva de hereditariedade "biologica" (1n "Reconhecimento de paternidade e seus efeltog", Forense, 1977, p. 128). A nova ténica acabou por naterializar a prenoniçăo do reapeitado furista.

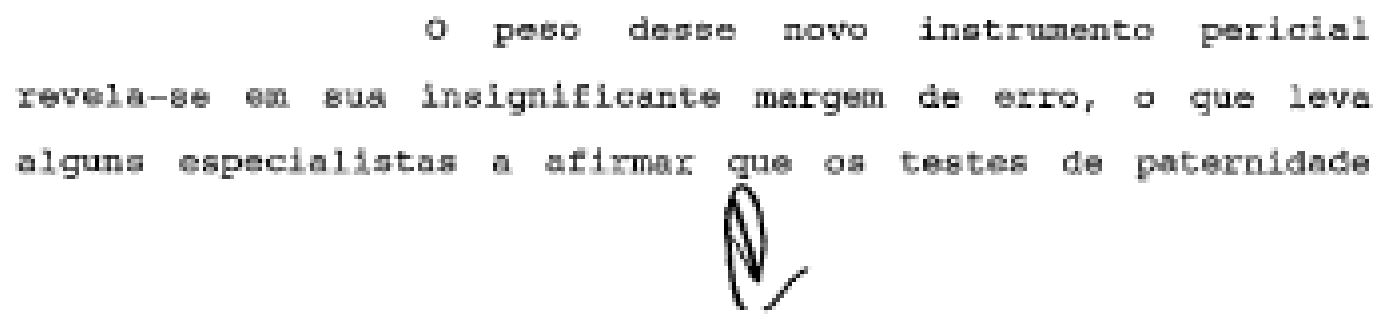




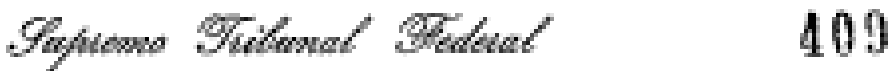

HIC $71,373-4$ Rs

pelo exane direto do puh - geralmente felto no sangue, embora posan dar-se em qualquer outro tecido do corpo que o contenha, ostenta confiabilidade superior a 99,994. A certeze cientifice proporcionada pela nova técnica oferece ao julgador um elemento solido para a conetruçtó da verdade.

De outro lado, observa-8e una superlativa atençso do legislador, a partir da Carte ce 1988, para com os direitos da criança e do adolescente. As inovaçöes eonstitucionais no capitulo da familia, da arianģa, do adolescente e do idoso deram nova conformaça do direito de exlança, de que $\theta$ exemplo o artigo 227 da Carta Politica. A legielaçto intraconatitucional tem acoopanhado, por igual, os avangos verificados neste escato dominio. Assim, a Lei 8,069/90, que diapde mobre o Entatuto da Criança e do Adolescente; a Lei $8.560 / 92$, que regula a investigaça de paternidade dos tilhos havidos fora do casanento, entre outras.

o que temos agora en mera e a questa de saber qual o direito que deve preponderar nas demandas de verifieaç̄o de paternidade: o da orianģa a sus real (e nằo apenas presumida) identidade, ou 0 do indigltado pai a aua intangibilidade fisica.

No Julgarento do RB 99.915 (RTJ 110/1133), sob minha relatoria, ponderei que ne parecla "ainda preaente na Justiça brasileira - cono, de resto, na eocledade brasileira - uma tendencia majoritaria a enfrentar estes cawos centrando atençöes na pessoa do investigado, e sempre empregando uma otica essencialmente penal*. E alentador observar, na hora atual, que a viaso individuocentrica, preocupada con as prerrogativas do direito do investigado, vai cedendo espaço ao direito elementar que ten a pessoa de conhecer sua origen 


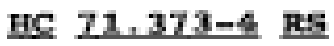

genetice. A verdade Juridlon, geralmonte fundada en presungito, pasaa a poder fidantiffcar-be com a verdade cientifica.

Esteve empre no dominio dea prova a difleuldade malor das açoses inventigatorias. Nä abstante a autononia propordionada pelo codigo de Processo civil ao julz no anpo probutorio, o problema que se the coloca 6 cono

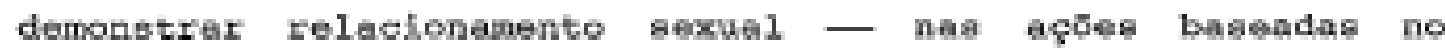
artigo 363-II do codigo civil -, eventualmente un ato singular, e a necessaris relaģa de causa e efeito entie ase Fato a a oncepgo da crlança. Prova docurental o tebtemunal so, quase entpe imposelvels. No canpo pericial, o denenvolvimento cientifico facilita busca da verdade, maa obstaculos cono a recuga a nubmiseto ao exame podert ocorrex, Deve o julgador eaber valarar, com og demaie elementos de prova, a ineubordinaglo. $A$ recusa mesma induz a presungato de paternidade, racilitando o destecho da denanda, man renolvendo de modo inatiafatorio o tena da identidade do investigante.

Provas perictala vinhan nervindo ate pouco tempo atrifa, para produsir apenas a certoza negativa da paternidade. De outro nodo, condizian eo non liquet no eampo da clanela, a buaca de forman menos neguras de convinģa. con o novo exame burge, pela ves primeira, a posstbilidade de ge aubstituir a verdade rieta pela vordade real. Ha hoje una tedentea que proporciona esteza tanto para okeluebo cono para confirmagtio do vineulo genetico.

4 aerto ainda, eono ponderou o Miniaterio Publico Foderal, que a recuga do investigado fimplica descumprimento de um adever proceseval de colaboraça, normativanente poeto no artigo 339 do CPC, verbia:

$$
. \mathrm{N}
$$




\section{Saptuemo Titumal Sedval}

프 71.373-4 ks

Art. 339: 'Ninguém se exime do dever de colaborar com o Poder Judiciario para o descobrimento da verdade"."

Sustenta, meis, o subprocurador-Geral

Claudio Fonteles:

"Nem se quefra argumentar, em paralelo com o Direito Processual penal que, neste, o direito de calar tem previsāe constitucional (artigo 5\%, LXIII), porque 4 repudiada a auto-incriminaģso cogente.

Certo, mas as perspectivas săo inconoilisveis.

o processo persegue a verdade, qualquer que seje sua naturezat ponal; oivil; ato.

Nas, a tal deslderatum, a quando o conflito poeme entre a Sociedade e o Individuo para o privar ou preservar a Ifberdade - porspeotiva tipica do processo penal - ningub́m pode aer obrigado a suto incriminarmese.

Se, todavia, o conflito pocme entre o filho investigante e o pai investigado a que se estabelega, ou nato, o vinculo familiar - porspectiva tiplea do processo civil - ninguëm pode furtar-se a colaboragāo na definiğăo deste vinculo."

Weste trilha, vale destacar gue o direito ao proprio corpo nlo 6 absoluto ou ilimitado. Por vezes a incolunidade corporal deve ceder espaço a un intereses preponderante, como no caso da Kaciną̧⿸to, en nome da sabie 
HC 71.373-4 FB

\section{2}

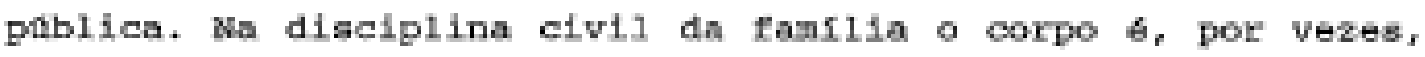
objete de diretes. Estou em que o pringlpio da intangibilidada do horpo humano, que protege un interesag privado, deve dar lugar a diretto h ldentidade, gue salvaguarda, an titina Analise, un interesce tarbem poblico. Nao fol Beg razao gue o lagialador whelbulu a parquot, b viata da inportancia da determinaço do vinaulo de t1liagio, a inieietive para que, em dotominodas eireunstancias, intento a Investigatbria do

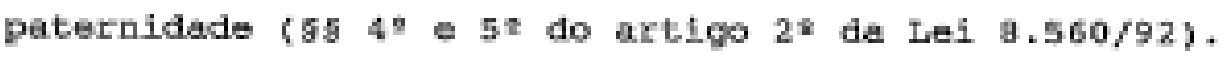

A Conetituica o ciara as pregeituar

"Art. 227 . E dever de fimlia, da goolodade e do Eotsdo angegurar a crianga o no adorasoante, com absoluta prioridade, o direlto d vida, a aado, a alimentigo, a ducapso, wo Iaser, a

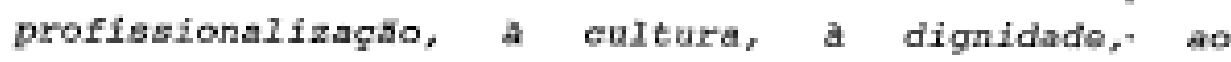
respotto, A Ifberdadie a a convindnola romiliar e comuntefria, alen do coloch-1os a balwo do toda forma

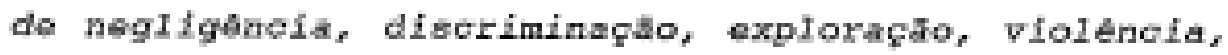

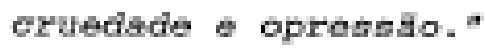

A lei bo6g/90 — Ratatuto de Criaga $a$ do

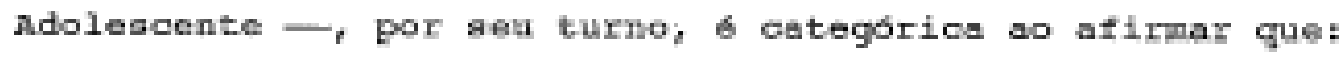

'Art. 27 reconheoiadoto do eatado do Riliegto de direito poraonaliandwo, indiaponivel a imprescritlvel, podendo ser exeroltado oontra os pais

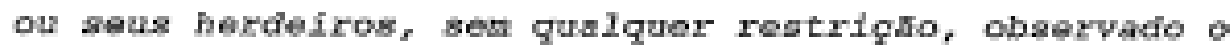
Bagrado de Juatich."

0 inpetranter alaga que a ordam do enducáo 


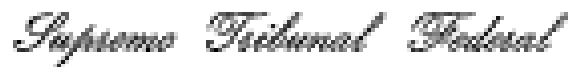

\section{He $71,372-4$ BS}

expedida contra mi afronta o artigo 332 do codigo de procegso civil. Da sua 6tica, o exame of ilegltino, ja que ninguen pode ser constrangido a aubneter-se a prova pericial contra eua vontade, ocorre que a lei, conquanto nito autorire diretamente o exane hematologtoo, como qualquer outro exane, 4 geral. Tem o magistrado a faculdade de determinar a provas que julgat necesearias A Derrelta inetrupto do procesto, podendo a parte, por iqual, propor a realigaço de todas aqualas an direito pernitidas, tal cono fez o paciente en sua contestaça ifla. 37). E o que diz o artigo 130 do coc, emplenentedo pelo artigo 332, que Lnclul todos os mefos moralnente logitimos, alnda que nfo especifleadoa neate esdigo." E 6 eontundente, a relaçso de pertinencia entre a prova pretendida o objeto da açä, onde se discute o tema da paternidade.

Lembra o impetrante que nas exlete 101 que o obrigue a realizax o exame. Haveria, assin, afronta so sitigo 5\%-II de CF. Chega a afirmar que aua recuea pode ser interpretada, conforme diepse o artigo $343-5$ 2e do CPC; coma wia confissto (fle.6). Mas nata ne parece, ante a ordem Juridice da republica neate flani de acculo, que iseo frustre a legitima vontade do julzo de apurar a verdado real. A Lei $6.069 / 90$ veda qualquer rentriço as reconhecinento do estado de filingro, a earto que to recuea eignificara uma restriça a tal reconhecinento. 0 nacrificio imposto a Integridade fisica do paciente 4 rialvel quando confrontado oom o interesae do inventigante, bem aasin con a certesa que a prova pericial pode proporcionar a deciudo do magietrado.

Wn ditino dispoltiwo constitucionsl pertinente que o Investigado diz ter aldo objeto de aftonta 40 que tutela a intimidade, no ingiao $x$ do art. 5\%. A propolto, 


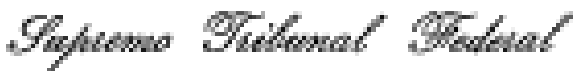

HC. $21,373-4$. BE

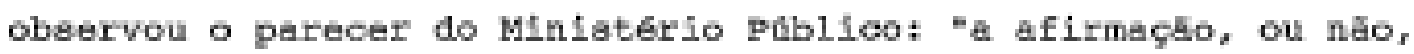
do vinculo tamiliar nilo fe pode opor ao direlto as proprto Kecato. Aesim, a dita intimidade do un nato pode esquda-1o h pretanedo do outro de to-10 como gerado pelo primelro", 9 malia a Constituigäo impōe oono dovar da famflia, da aociadnde do Eatado asecgurar a arianga o direito a digmidader ao reapelbo, nlem de eoloca-la a salvo de toda forma de negligencia. Como bem pondorou a parquet fedexal, no destecho de But mantegteptio, "nis há forma mais grave de negligencia para con wha peanou do que detxar de assunit a responeabilidade de to-la fecundado no ventre materno ..." (f1a + 206).

Estas as ciccungtancias, parece-me quo o

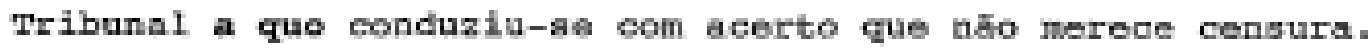
Indefiro o podido.

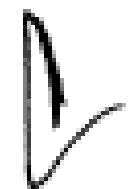


HABRAS CORPUS NE 71,373-4 PARA1BA

$\underline{\mathrm{y}} \mathrm{I} \mathrm{Q}$

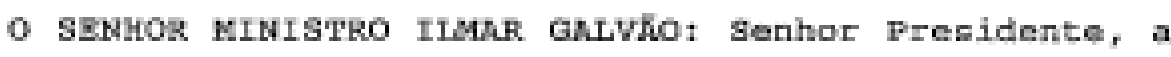
recuan do riu em rormecer o meterial necebedifo a exame portcial "DNA", conguanto posan conflqurar uma prova indicidria du paternidade, que pode satiafazer por Intelro ao autor da agrio.

Primeiramente, porque ge trata de maro indrelo, insuflciente para autorizar une presunça de paternidade suffiente para a prolagtio de sentença oontrarta ao reu; "cono ocotre en apoes metanente obtigacionais.

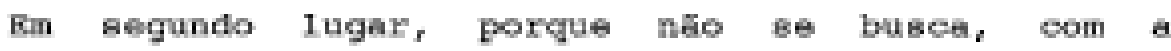
invegtigatoria, a gatiafaçio de interesen meramente patrimonial, mas, sobretudo, a oonsecugaso de interesas foral, que se encontraxa rappoata na reveleço da verdade real acerea de orfgem biologiea do preteneo filho, posta en divide pelo proprio rea ou por outren.

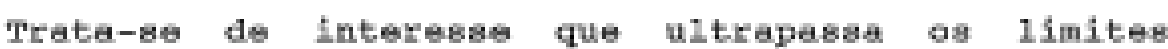
Batritos do patrinonialidade, posaudndo nitida conotacio de ordem publica, agpeoto sufioiente para suplantar, en favor do pretereo I1Iho, o egoretion diredto h rocuan; fundado na incolumidade fleiga, no caso, metada en proporgat ridfoula. Wá 6 por outre razao que, nas apoes da especte, que

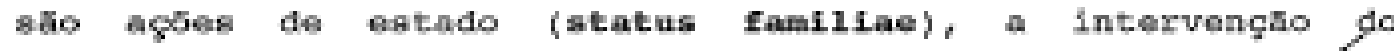


Be $71,373-4$ PB⿴囗十

Miniaterio phbileo abrigatoria (art. 82, II, do CPC). Mo confronto dos dois valores, Senhor Prealdente, noso tenho dovidn on poatelonar-me em favor do filho, raxăo pela qual meu voto e no aentido de indeferfir o habeas oorpus.

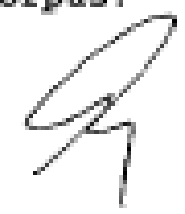

Ians 

Tribuna1 Foderal, pudeane defrontar-me oom un guadro de tho extravagante - aob a minka sptica e oom a devida venia dos Senhoreg Miniatros que me antegederan - abugo de poder a Implicar Inagival conatranglmento para o Paciante.

Ha esptoie, "tem-se que, enl determinado procebro civil - esto de Investigacto de paternidade - requeret-se las Autoras devem te-lo feito con o objetivg de comprovar fato conatitutivo do direltop o axana danominado DNA, am relactio bo qual neo coloco duvldes quanbo a valia, A seguranga do reaultado. Aquele que deveria fornecer, do proprio gorpo, a mubstangin indispenetvel para que fosse realizado recusou-se a

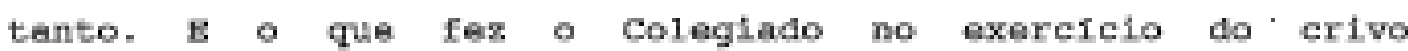
revinionalz Tal como a Julzo, determinoi a submisedo do

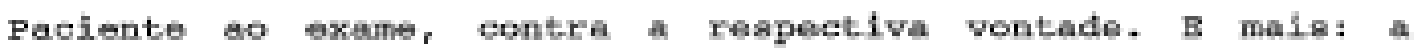
conducta "debaixo de vara", como se foese poselvel colocar o paciente en uma camian do forea e al lova-io ao laboratorio para, imobilimado, ver recolhido, do proprio corpo - repibo - 0 naterial nechatin io.

Benhor Presidente, para mim a vioneid o impir e

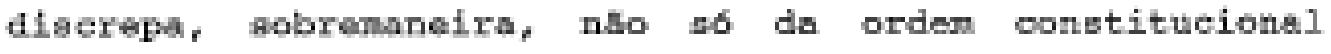
vLgor, bono tambeim das nomas ingtrumentais conung aplicaveis (a) 


\section{Shenowe Tilanat Mratal}

볻 71.373-4 $\mathrm{BS}$

espécie. \& certo que inexiste, no codigo de Processo Civil, disposttivo cue discipline, de forma expresas, o tena. Todavia, hi outros doe quaie, ume ves interpretedos, emanam 1 uz suffciente a definiçso das conseqübncias da recusa. Refiro-me ao teor do $32 \%$ do artigo 343 do codigo de Processo civil, quanto ao depoimento pessosl, à intimeçāo para presta-10, mostrando-se o destinatario silente e deixando de comparecer en Julzo. Qual 6 a consequenela prevista, expressanente, no código de Processo Civil? A execuçto especteica da ordem judiciel? Năo. o legielador encontrou outre soluçăo: a admissibilidade ricta, e certo - dos fatos.'Distingam-se as posiçóes - de róu e de testemunha. Dou mais un exemplot o do artigo 359, que euida da exibiçäo de documento, guando a parte e intimade para tanto, mas nto o faz. A repercusatio juridica nso 6 , em si, a pristo ou a aneaça a menma, para que apresente o docunento.

No caso conereto, o Julzo competente, que é 9 da investigaçäo de paternidade, sabera dar à recusa do Ré, ora Paciente, o efeito juxidlco-proceasual mais consentsneo, isto no aabtto da prova e da distribuiçăo respectiva, afastada a execuçto especifica e direta da obrigaçăo de fazer.

Senhor Presidente, quando o nobre Relator cómeçou a relatar este habeas-corpus, a materia pareceu-me de simplicidade tranciscana, mas vejo que năo $6, \theta$ que os enfogues - ejú temos dois votos no sentido da denegaça da ordern - eấo diversos.

Pę̧o vầnia para subsorever o voto vencido proferido perante a Corte de origen pelo ilustre Desembargador Jos6 Carlos Teixeira Giorgis e que tem o seguinte teor: 


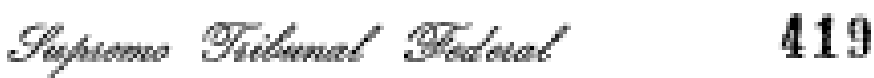

플 71, 373-4 BE

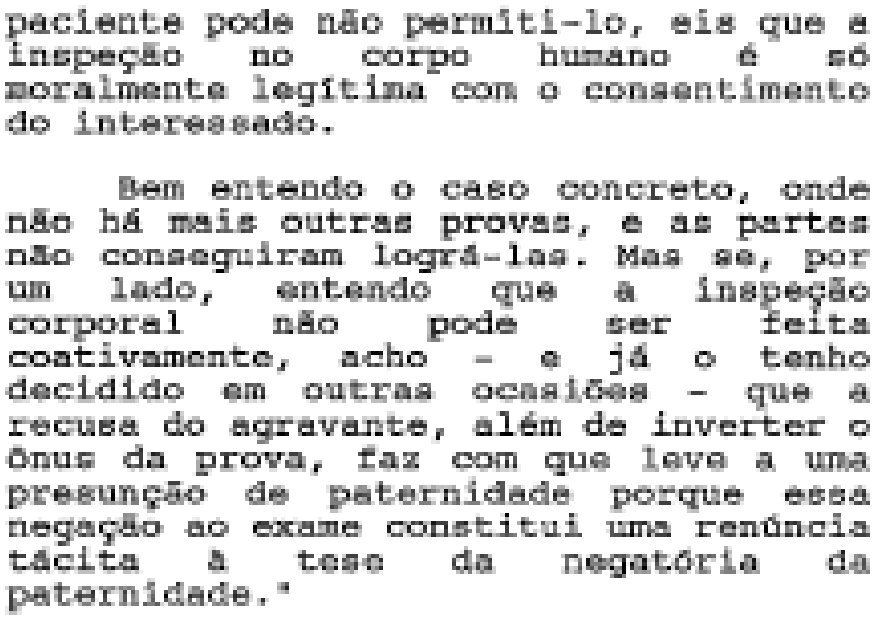

Minguén esta compelido, pela orden juridica, a adentrar a Justiga para questionar a reapectiva paternidade, da nebmet forma que há consequancias para o rato de vir aquele que 4 apontado cono pal a recuar-ae ao exame que objetive o egclarecimento da aituaçio. E certo que compete aog cidadson on geral colaborar com o Judiciarior ao nenos the buede da prevalencla dos renpectivon intereages a que o bacrificlo - an especie, uma rimples espetadela - na 6 to grande ageim. Todav10, principlog conett tuctonata obstaculizan a solucho dada A requa. Refiro-me, en primeiro lugar, so da legalidade, no que ninguom o obrigado a farer ou delxar de fazer alqum colah entio en virtude de lei. Inexiste lei reveladora de amparo a otdem judiclal atacede neate babsas-corpas - no santido de o

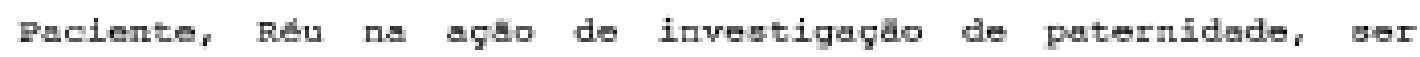
onduzldo a laboratorio para a colheta do material indiagenanvel ao arase. Anda que houvenad, satarta maculada, conilderados os interesses en queatao - eninentemente peasoais a Anegivel earga patrimonial - pela inconstitucionalidade. Digo 1ato porquanto a Carta Polftion da Republica - que o Dr. uliagea cuinarien, en perfeita sintese, apontoi cono a carfa 
HC $71.373-4$ Rs

\begin{abstract}
Cidads: - consigna que sāo invioláveis a intimidade, a vida privade, a honre e a imagem das pessoas - inciso $\mathrm{x}$ do rol das garantias constitucionais (artigo $5^{2}$ ). Onde tican a intangibilidade do corpo humano, a dignidade da pessos, uma vez agasalhada a esfruxula forma de proporcionar a una das partes, en demanda civil, a feitura de una certa prova? o quadro 6 extravagante o em boa hora deu-se a impetraçaso deste habeas-corpus. B irrecusavel o direito do paciente de năo ser conduzido, medisnte coerçăo fisiea, ao laboratorio. B irrecusavel o direito do paciente de naso permitir que se the retire, das proprias veian, porç⿰丿丶⿱⿰㇒一乂 seja, para a realizaçăo do exame. A recusa do paciente ha de ser resolvida năo no canpo da violencia fisica, da ofense a dignidade humana, mas no pleno instrumental, reservado so Ju1zo competente - ou seja, o da investigaçöo de paternidade - a anflise cabrvel e a derintçăo, sopesadas a prova coligida, e a recusa do xu. Assim o o porque a hipbtese nobo 6 daquelas am que o interesse pablico sobrepoemse ao individual, cono a das vacinaçöen obrigatórias ex epoca de epidemias, ou mesmo o da busca da preservação da vida humana, naqueles conhecldos, casos en que conviçбes religiosas arraigadas acabam por conduzir a perda de racionelidade.
\end{abstract}

Por tudo, peço venia ao nobre Relator para conceder a ordea e cassar a deterninaçăo no sentido de o Paciente ger conduzido, "debaixo de vara", para colhefa do sangue viabilizador do exame, ao laboratorio. 


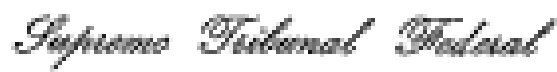

$10 / 11 / 94$

TRIBUNRL PLZNO

BABEAS CORDUS 뜨 21.373-4 RXO GRANDE DO SUL

Y 92

o sr. Minietro Carlos velioso: - Sr. Presidente, a Conctituiça estabelece, no art. 227 , caput;

"B dever da tamilia, da socledade e do Bstado assegurar à criança a ao adoleseente, con absoluta prióricade, o direito a vida, a mafide, a alimentaģão, à educaçsio, ao lazer, a profissionailgação, a cultura, A dignidede, ao respeito, a liberdade e a convivencia faniliar e conunitsria, alcm de coloch-1os a salvo de toda forma de neglfgencia, diecrininaçto, exploraçso, violencia, crueldade c opressão."

Va1 alem a Congtituiço. No $56^{2}$ do nesao artigo 227 eatabelece:

"O8 fllhos, hevidos ou tão da relação do casamento, ou por adoçăo, terăo os ziesmos direitos e gualificaçoes, probbidas qualaquer designaçoes digcriminatorias relativas a r1. iaçăo."

Das resultar paxa o rilbo, as que peneo, 0 direito de conhecer o seu pai biológico. Base direito se insere naquilo que a Conetituiçäo assegura a criença e a adolescente: uouls 


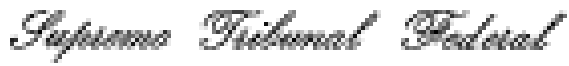

HC $71,373-4$ BS

o direlto a dignidade pessoul.

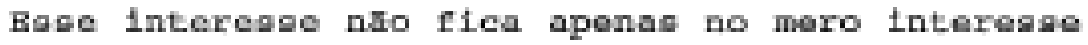
patrimonial. A conesquencia da nao submisedo do ore inpetrante no exame, mpontou o sx. Miniatro Mnroo Aurelio, geria empreatar

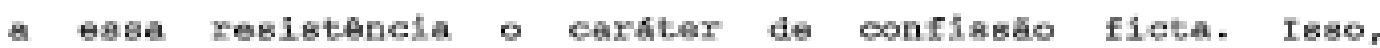
entretanto, ae tem inportanoia para a satigtacio de noros

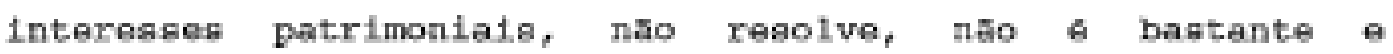

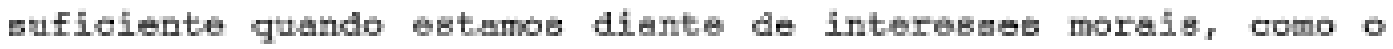

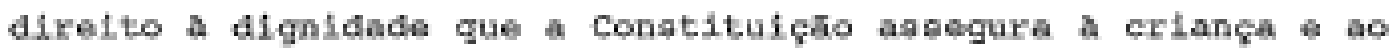
adoleacente, certo que egha nesma constitulgajo assegura ans filhos, havidos ou näo ds relagäo do casamento, ou por adopto,

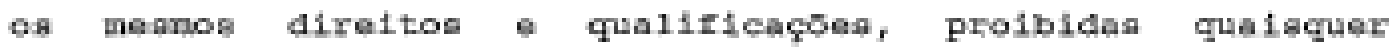
desiqueter discriminatorias nelativas a filiacto. Tanbem desse diepositivo onstitucional - 5 bl do art. $227=$ defluem

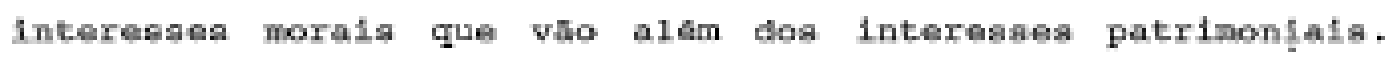
ora, Br. Presidente, nib ha no mudo interenge moral malor do que eate: o do Ilbo conbecer ou saber quen 6 o seu pal biologion.

Asein, tenho cono perfeftamente aplickvelis, no

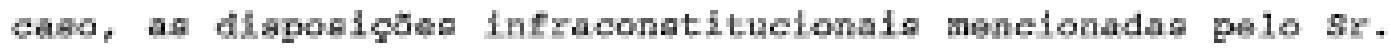
Minietro Relator, especialnente a que es fincreve no art. $3 \mathrm{~g}^{2}$ do cPc. 0 exane, no camo, tabrigatorio, deve ser realizado.

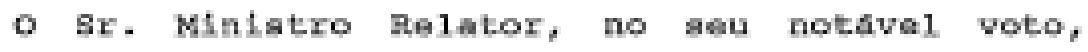
delxou claro que, tendo em vista o desenvolvinento das cibnaias

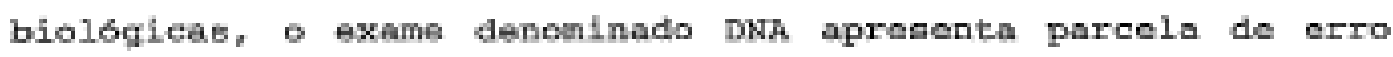
diminuta, oferecendo pratichmente certara intogral. Penco que se inagre no diretto a dignidade, que a constitulço anogura 
ao menor, ou no direito que a Constitulę̆o asgegure aos filhos no 862 do art. 227, ter en măos ease exane. Esse filho terk, Ielto o exame, possibilidade de conhecer, con certeza, o seu pai biologico: ou a possibilidade de saber, con certeza, que o individuo que está a negar ser o seu pai biológico, năo o 6 , na verdade.

Regiatre-se que nå presta obsequio a atgnidade de ura pessoa, ser esta sustentada por outrem, como se fora seu pai, simplesmente porque esse outrem n⿳亠丷厂 quis bubreter-se a exame, Hicou sujeito a pena procensual de confissajo ficta. Isto, vale repetir, resolve a questio patrinonial. Nessas questöes, entretanto, não conta apenas a questäo petrimonial. Questōes como esta demonstram, alias, que o direito de femilia nưo contêm apenas disposiçoes privatisticas, que o direito de fasilia 4 multo mals pabileo do que privado.

Hoje, quando o direlto de fanilia apresenta alto grau de desenvolvimento, quando as elenclas blologicas alcançaram, tamben, altissima evoluçăo, a resistencia á exame lembra a reaiationcia que foi oposta, no seculo passado, a obrigetoriedade da vacina. o desenvolvinento do direito de famflia, o desenvolvimento das ciencias biologicas, impede, a esta altura, o setiehismo que se costuna emprester a certos meios de prova.

Com essas breves consideraģoses, peģo licenģa so Sr. Ministro Marco Aur61io, que infetou a divergencia, para acompanhar o voto do Sr. Minletro Pranelsco Rezek, Relator. 


\title{
HABBAS CORPUS N2 $21.373-4$ RTO GRANDB DO SUL
}

\author{
v 오 $\underline{\underline{x}}$ 으
}

O SENHOR KTMISTRO SBPOLVEDA PERTBNCE; Senhor Presidente, O brilho dos votos que the antecederan mostra que o caso retrata un confronto de valorea conatitucioneis relevantes.

No entanto, a esta altura, os argunentos estalo poetos. Convenceu-me o Sr. Ninistro Relator, Franclnco Rezek, a os que o acompanharan de que năo se pode opor o minimo ou para usar da expresebo do eminente Miniatro Relator - o risivel sacrificio imposto a inviolabilidade corporel a eminencia dos interesses constitucionelmente tutelados a investigaço da propria paternidade.

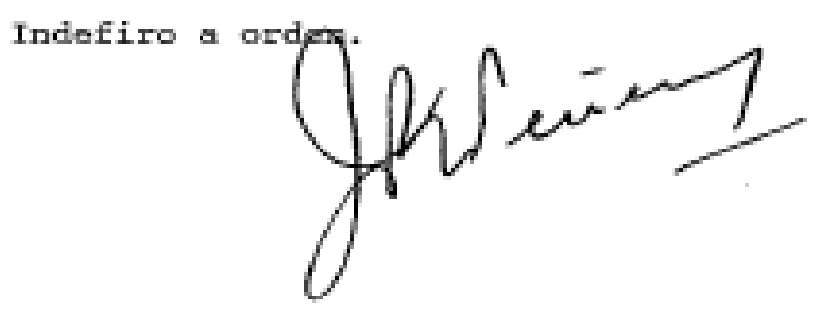

Ibe/ 


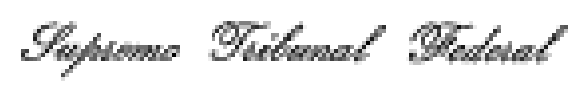

$10 / 11 / 94$

HABEAR CORPUS
KE. 71.373-4 BTO GRAKDE DO BUL

TRIBUNAT, PLEKO

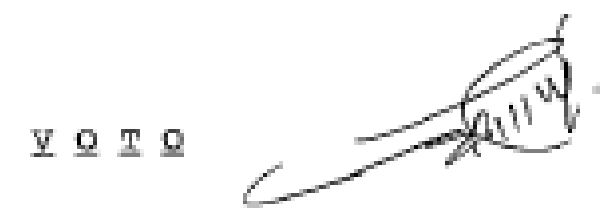

O SEMHOR MINTSTRO SYDNEY SANCHESI -

Sr. Presidente, peço venfa eo Minfitro-Relator e ade que o seguiran para acompanhar os votoa dos Ministros MARCo AURRLIO A CBLSO DE MELLO.

Não me parece poseivel conduzir alguem a juizo e aubmete-1o, contra sua vontaide, a ate a força, a extraço de aangue, conto tanbếm naso ne pareceria razodvel forçs-lo a ejaculaẹāo, para obtençso de esperna, nen forçar alguém a fornecer elenentos graficos, de proprio punho, para exame grafotecnico.

Mesno no proceseo penel, o reu pode ser citado peşe comparecer a interrogatorio e năo comparecer. Podera o Juiz, nesse caso, conduzi-lo coercitivanente ou tera que decretar a revelia?

Neano que se adinita que posan ou deva ser conduzido 'coercitivamente, não poderd ele se celer? claro que jim. parece-ne repugnar a naturese das colsas e a propria natureza humana compelir algubm, contra aua vontade, a servir cono objeto de prova, com violagato a intimidade até do corpo fart. 5\%, inciso $\mathrm{x}$, da C.F.).

A recusa, obviamente, poder6 repercutir, negativamente, contra aquele que dela se vale, podendo-ie, ate, considerar provado o que se pretendia provar com 0 exane recuesdo.

Alisa, em situaçăo como a dos autos, a recusa do 


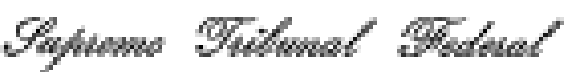

\section{HC 71.373-4 aㅗ}

\section{6}

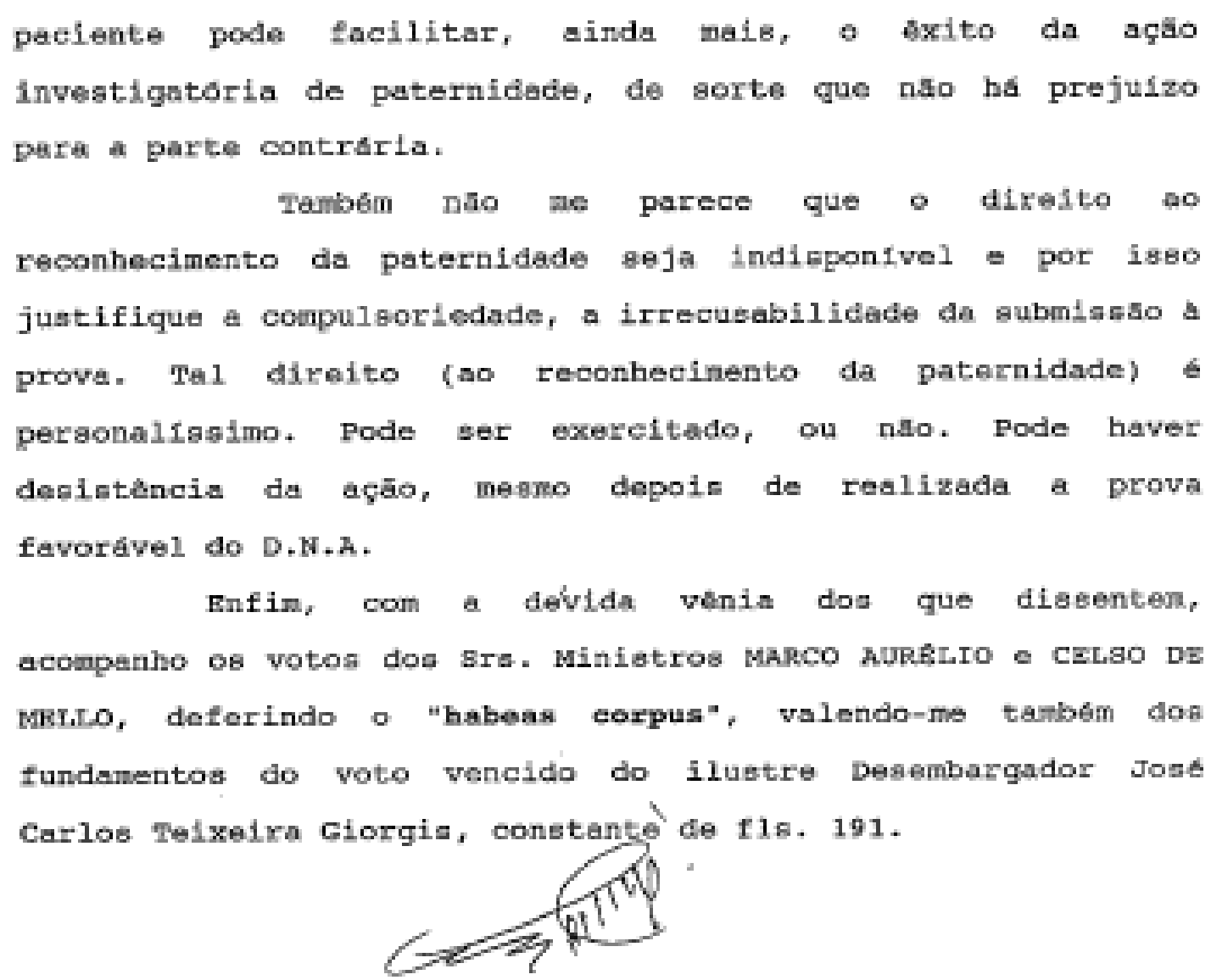




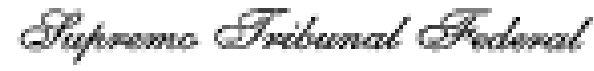

427

10.11 .94

THIDCMIRL, PI.TIO

HE $71,373-4 / 130$ - RIO GRANDE DO 901

Y 0 T

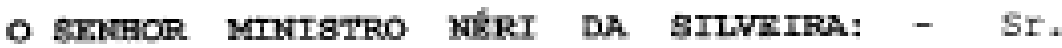

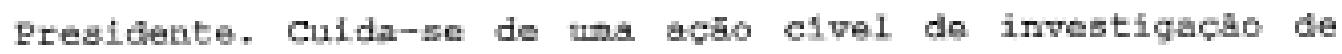
paternidade. No curge dease procedimento fol requaridn a realizacto de certa prova pelo autor, o reli opsa-3e A efetrqacio dessa prova, porque, para tanto, mister ge raxia dispor de ate pxoprio corpo. Perdunta-89: o ren pode opor-Be A realizacto de ume prova podida pelo autor con objotivo de esclarecer a verdade dos fatog? He un dispositivo no codipo de Promeno civil, acerea das provas, art. 339 , que eatabolede:

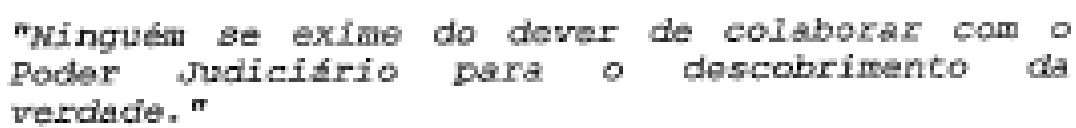

b da indagar se esae comando tem a forpa de compelir o row polo dover de oplaborar con o Poder

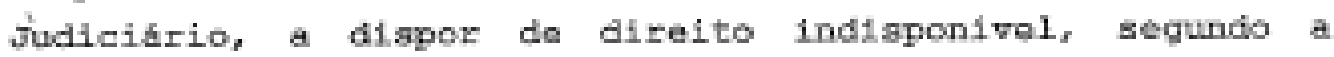
conatituicho. En verdado, de soordo com a constituicko, $A$ direlto Individum indigpontrel 0 que pretende, aqui, aseagurar, por anta via do "habeas corpus", a paciente. 0 ton no quer que the and extralo do corpo material hemboldgioo dentinado ao exame do DN. Ferfunterse: 0

$$
b^{2} \min
$$


Boder Judiciário pode obrigar alguan ta subaber-ge a ease tipo de exane? o puctente onsidera constrangimento ilegal ser obelgado ab exame aludido. Em favor desen poslcionamento, invoca-se o disposto no inciso $\mathrm{x}$ do art. $\mathrm{g}$ " da constitufico que assegura a inviolabilidade da intimldade, a aqui cabe ver compreondida, tambem, a inviolabilidade do orpo. Ba outro disposttivo que, a mau

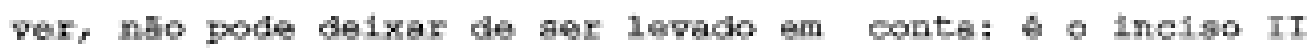
do art. $5^{\circ}$ da constituicto que reza:

"ninguda sard obrigado a fazer ou delwar de farer algum colsu sonso en virtude do lat."

Nao ha lei alquma, obrigando pai presumido, ou quem rou on acho de invatignefo de paternidade, a rujeltarse a prova desse raturara, que prosaupse, para a sue consecucas, naterial extraido do corpo do proprio sur. Dessa maneira, se bato ha sequer 1el, - ponto que aeris questionavel, se exiatisse = requiano assa materia, ninguen pode aer realmente obrigado, compelide a se sujeiter a tal exame. Dir-se-h! mas se niso for constituida ensa prova, sert Irustrada a eventualidade da procedencia de acro o on laso o paciente estart, nuto só delixando de colaborar con o Poder Judiciario, cono a impedir que o autor veja assegurado, pela ordan turidioa, direito que eata a pletteer ao Poder Judicitirto the soja reconhecidot a relacto de filiacto com o réu. a proprio sistens constitueional, entretanto, raspondo a essa queation, quando so adnite, om materia de acho do investigacto de paternidade, o decreto de sus procedencla, nto so en razio de provas documentals ou testemuniais, mas tambén por indictos a por presuncos.

$$
\text { 2. } / \mathrm{b}-\mathrm{x}
$$


Trata-se, é certo, de demanda, ordinariamente, com prova de diffcil produço. Suatenta-se, pola, que a prova pretendida pelo antor é extremamente eticlente, de alta qualidade, no processo de investigaçă de paternidade, tornando-se, quase definitiva, a cortera a embasar o jufzo do magistrado. quando positivo o resultado.

No caso concreto, o voto vencido do ilustre Desembargador Jose Carlos Telxeira Ceorgis colocou, em ternos precisos, a quaestio juris. A recusa do réu implica presuncio de reconhecimento do fato da paternidade e ten que ser assin tratade, com consequencie favortivel ab autor. Dirse-ba sempre algubn poderá levantar duvida e $15 s 0$ feriria a dignidade do autor, poxque o conplexo das provas năo seria derinstivo. Tanto nuaa circunatancia cotto na outra, ajuizada a aça, a paternidade scmante será reconhecida por via de decisio judtctal, que e sempre susceptivel de ser discutida) dal os recursos. Esta prova, que hoje se tem cono quase incontrastável, admite, entretanto, erro. Há, teoricamente, a possibilidade de exro.

Desaa naneira, penso que se resguardan os prineiplos constituctone1s da privacidade e da lejalidade, que favorecen wo paciente; nâ resulta do decisum, no ceso concreto, no que concerne a realizaço da prova, prejuizo definitivo ao autor, porque hâ uma consequancia dessa negativa, qual seja a confissăo, o reconhecimento da paternidade. Em verdade, om principio, nenhua juiz deixaxa, diante da recusa do rêu de submeter-se ao exame do Dar, de dar pela procedencta da acto, tendo nessa recusa o reconhecinento do reu quento a paternidede. Por isso nao quer se sujeitar ao exame que asbe ser bastante preciso.

$$
\text { ใ. Whin }
$$


o gue considero, aqui, em debete, nho them esse

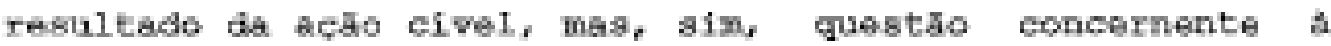

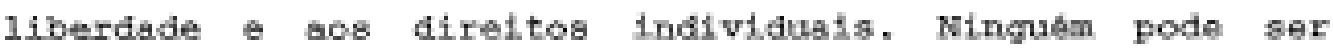
conatrangido, contra sua wontade, a un taxane que $1 m p l i c a$ extracho de materlal homatolígloo de sel eorpo.

A.sim sendo, ponta a questên nesaes tarmos, com a devida venta do brilhanta poto do enltutente Relator e dos

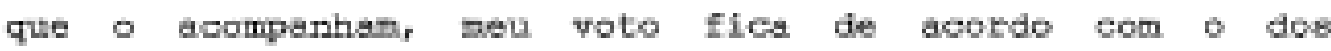

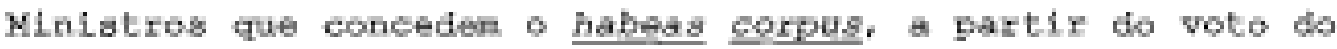
Gr. Ministro Mareo Nurelfo.

9. $n+m$

aN근 


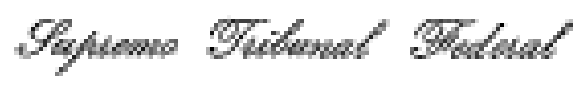

\section{1}

$10 / 11 / 94$

TBIBUNAL PLENO

HAREAS CORPUG NI 21.373 -4 RIO GRMDE DO SUL

$\underline{\underline{Y}} \mathbf{\underline { T }}$

o SENHOR MINIGTRO MORETRA ALVES! - BT. presidente, o direlto a inpostgaçao de paternidade 4 un direito disponiver, tanto beim que se pode deikar de propor a agho. Adenala, ninguém pode propo-2a, fa gue 6 un diteito pereonalianimo, depola da morte do filho que podaria pretander eser investiqapto. Estanos, pois, diante do dols valores: un diponive1; outro, gue a conatitulgio neaguarda, e gue 4 o da

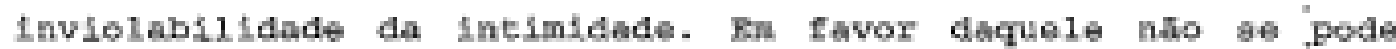
violar este.

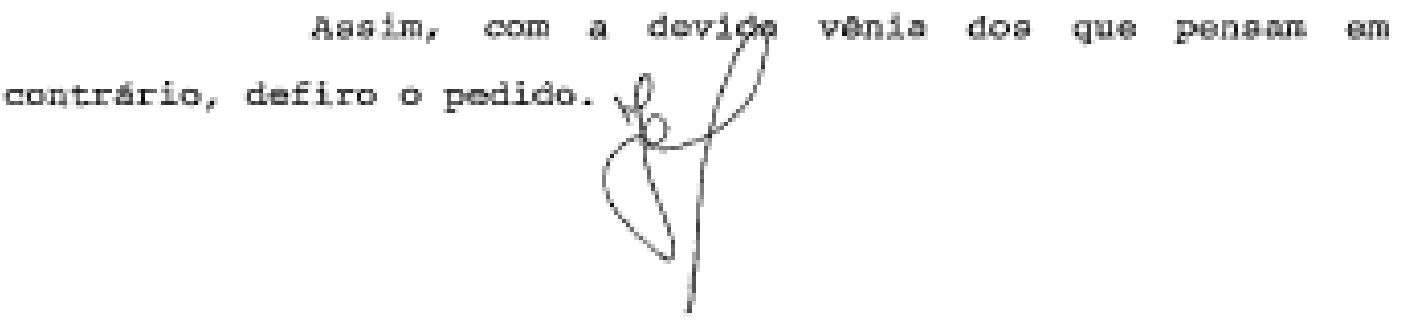


O SEMROR MINISTRO OCTAVIO GALIOTPI (PRESTDENTE) : Peģo vénia, ao eminente Relator e aqueles que o seguiram, para acompanhar o voto do Miniatro MaRCo AuRELIO.

E certo que não 4 meramente patrimonial o direlto que ne pretende ver declarado na aç̦o de inventigaçăo de paternidade, mas também alo 6 un direito indisponivel, B 6 un direlto individual, nô corresponde a interease coletivo, como sucederia se se tratasse de un processo criminal, ou também na hipotese, agui aventada, da vacinaçăo, que responde a proteçăo de un lnterease de asubde póblica.

De recuse do paciente, decorre, no processo civil, uma presungio favorável as alegagbes da parte contrária. Bsaa parte, cono autora da açso, supoesese que

iconheça, ou pretenda conhecer a verdede, a eleger o rea da eçä̊ de invertigatơria.

Se, a tal convicçăo propria do autor, vem a juntar-se a declaraçăo do juiz extrasda, ou nāo, de una presunçoso, a decorrer, por sua vez, do procedinento da parte contreria, - penso que naso podera o autor, legttinamente, considerar que nó esteja eatabelecida a verdade.

Acompanhe, por 1smo, o douto voto do Ministro Marco nurítio, defertindo o pedido. Le. 


\title{
Primuirto
}

\section{FXTATO DE ATA}

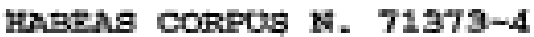 \\ GRIGEM i RIO GRANUE DO SUL

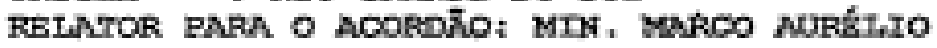 \\ FRCIE - : JOSE AKTOWIO GOWBS PINUETRO MACHADO \\ IMPTE. $\quad$ JOSE ANTONIO GOMES PTNHEIRO MACHADO \\ COATOR : TRTOMTAE DE JUSTRCA DO ESTADO DO RIO GRANDE DO BUT.
}

Dedske: For proporta do Ministro Franciapo menk (Reletor), Turna, por unanimldada, deliborgu atetar ao Flentrio o julqumento do presonte habeas corpos. Ausentes ocasionalmente os

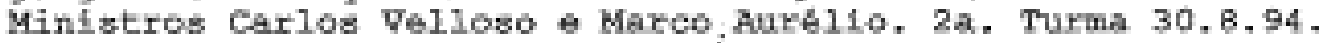

Dealabor Ror maloria de vatos o Tribunal deferiu o podido de haboas corpus, vencidos os Kinistrog Franciseo Bezek [Belatorj, Ilmar Galvá, carlos Velloas e sepalueda partance que o indeferiam. Votos o Presidente. Polator para o nodrdio o Kinistro Marpo AirA110. P1anate 10.11.94:

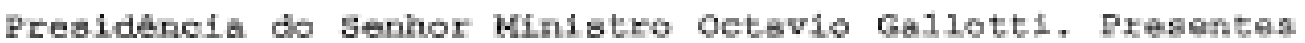

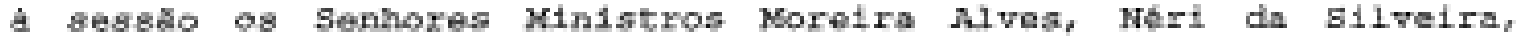
Bytney ganchas, Beptivede Pertence, Geleo de Mello, Garlod We1loso.

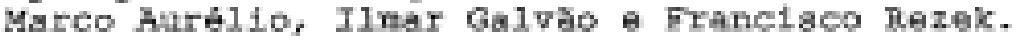

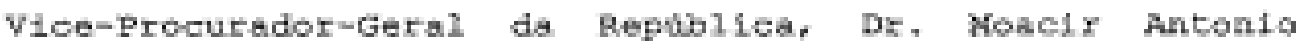
Machado 4 s1ra.

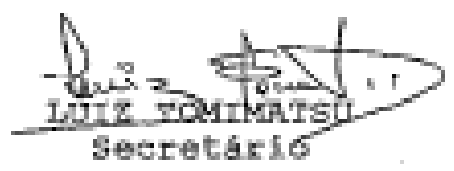




\section{Anexo II}

Seprome Eribunal Fedexal

SERVICOO DE JURLSPRUDENCLA

D.J. 15.05 .98

EMENTARIO $1910-01$
130

PJIMETRA TURMA

$31 / 03 / 98$

\section{HABEAS CORPUS $\mathrm{N}, 76.060-4$ SAKTA CATARTRK}

RRLATOR ; MIN, SEPÜLVEDA DERTXNCE

PACIENTE: NRAKTE JOSÉ MONTEIRO FILHO

IMPETRANTE: BLISA PIMENTA

CONTOR: TRIBUNAL DE JUSTIÇA DO ESTADO DE SMNTA CATARIMA

EMrmTa : DNR: submissâo compuls6ria so fornecimento de angue para a pesquisa do pNA: eatado da queståo no direito comparado: precedente do STF que libera do constrangimento o ré em açăo de investigaço de paternidade (HC 71.373) e o diasenoo dos votoe vencidos: deferimento, nåo obatante, do te na espécie, em que se cuida de aituaçio atfpica na qual ae pretende - de reato, apenas para obter prova de retorco - aubmeter ao exame o pai presumido, em processo gue ter por objeto a pretensa de tercelro de ver-ge declarado $\circ$ pai biológico da criança nascida na constäncia do casamento do paciente: hipotese na qual, a luz do princlpio da proporcionalidade ou da razoabilidade, se impóe evitar a afronta à aignidade pessoal que, nas circunatincias, a sua participaçăo na pericie substantivaria.

Vistos, relatados e discutidos eates autos, acordam os Ministros da Primeira Turma do Supreno Tribunal Federal, na conformidade da ata do julgamento a das notas taquigraticas, por unanimidade de votoa, em deferir o pedido de habeas-corpua .

Braa11ia, 31 de março de 1998.

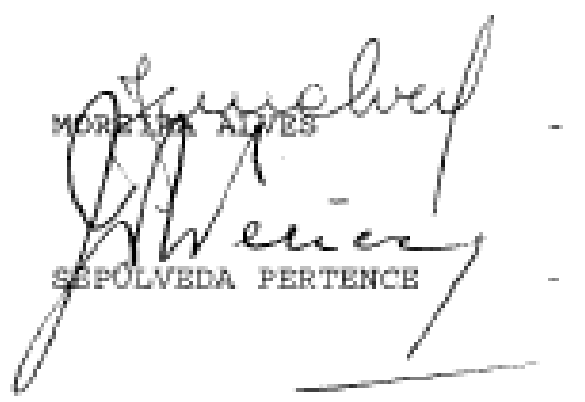

PRESTDENTE

RELATER

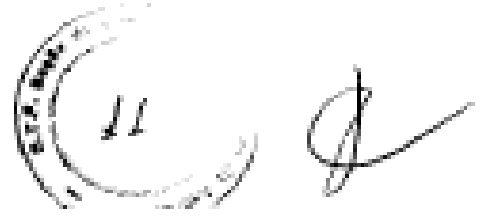




\section{HARXAS CORPUS $\mathrm{N}, 76,060-4$ SAMTA CATARTRA}

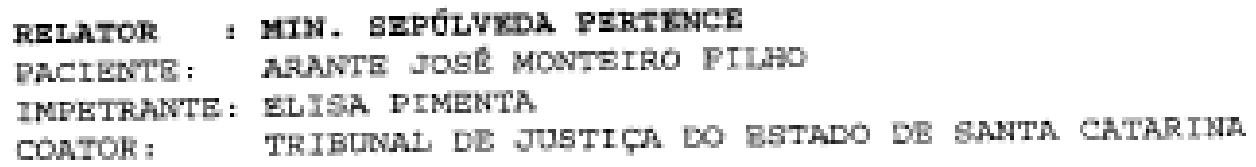

$\mathrm{R} \mathrm{B}$ I $\mathrm{A} \Phi \mathrm{B} I \mathrm{I}$

\section{- SEMHOR MINIGTRO SEPdLVEDA PERTRNCR - (Relator): Para}

deterir a liminar, s88im reauni o easo (v.2/E.587) =

"Pai presumido de menor nascido na constáncia de seu casamento, o paciente responde a "açlo ordinsirta de reconhecimento de filiaçăo c/c. retificaço de regietro*, movida por terceiro, gue ae pretende pai bioldgico do infance.

Ordenada a submissăo do paciente so exame DNA, en seu ravor se impetra habeas corpus, cow pedido Iiminar, para ilvrar-ae do constrangimento.

A vista do decidido pelo plensrio do Tribunal no HC 72.373, I0.12.94, M. Aurelio - posto que por majoria, contra quatro votos vencidos, incluido o meu, e năo por unanimidade, como equivocadamente assevera a impetractio a, náo posso negar a plauabilidade da resiatincia do paciente, no caso, en aituaçio aparentemente maig favoravel que a do interesaado no precedente.

Defiro, poig, a Iiminax para gue, até a decisáo deste habeas corpua, năo seja o paciente constrangido a gubmeter-se ao exame DNA; comunique-ge ao relator do Ag. 12406, do Tribunal de Justica de Santa catarina, e ae Jujz da I* Vara de Familia da Comarca de ploriandpolis".

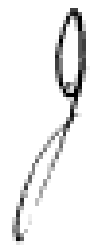




\section{Stepremo STribusal Shaderal}

BC $76060-4-S C$

\section{2}

Acrescento que a deciašo questionada 6 a acórdăo do Tribunal de Justiça de santa Catarina (f, 247) que, improvendo agravo contra $\circ$ despacho baneador, repeliu as preliminarea de carência da ą̧̄o, invocando para tanto decisāo do sTJ, da lavra do em. Ministro salvio de Figueiredo (f. 251 ss) - gue, de sua vez recorda, a do STF, no RE 80.805, Xavier, RTJ 78/534 - e manteve o acferimento de orden de aubmeter-ac o paciente, entăo agravante, so exane do DNA (v.1/f, 247), csseada, em conseqũenela, a liminar gue o auspendera $\{\mathrm{V}, 1 / \mathrm{f}, 135)$.

Das informaçoses da presidencia do Tribunal a quo - que vieram 1netrufdas com numerosas peças do processo principal já trazidas pela impetrante - eolbe-se mais, primeiro, que já foram rejeitados os embargos de declaraçö́ opostos pelo paciente å acbrazo que julgou o agravo e, segunco, que, efetivamente, a determinaça do Juiz de primeito grau para que fosse ele gubmetido ao exame as fol austada em cumprimento de liminar de habeas-corpue por mim. deferida ( $\mathrm{v}, 3 / \mathrm{f}, 603)$.

Eelo Miniaterio Páblico Federal, opinou o il. Subprocurador-Geral Mardem Costa pinto pelo deferimento da ordem, anotando $(\mathrm{v}, 4 / \mathrm{f}, 903)$ !

2. Tem razlio a impetrapilo, eis que diante das garantias conatitucionais da preservaçifo da intimidade e da intanglbilidade do corpo humano, o paciente năo pode ser corpelido a subweter-ge 20 exame hematologico de DNA. devendo a rocusa oox interpretada e avaliada no contoxto da prova segundo as balizas ditadas pola doutrina o pela jurisprudencia sobre o tema.

3. A questăo, aliá, fá fol objeto de apreciaçio polo plendrio do supremo Tribunal Federal, que

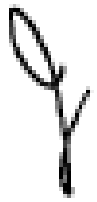




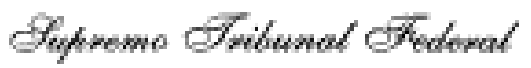

典 $76060-4-$ sc

deoidiu no gentido da tese da impetraço em acórdāo aseim ementado?

"ENENTA; INVESTIGACĂO DE PATERNIDADE - EXAME DNA - CONOUCT̃O DO REU *DEBAIXO DE VARA". Discrepa, a mais naio poder, de garantias constitucionais implleitas e expllcitas preaervaçáo da dignidade mumana, da intimidade. da intangibilidade do corpo huarno, do implrio da les e da inexecucăo especifica e direta de obrigaça de tazer - provimento judicial que, em aço civil de investigacto de paternidade, implique determinaço no sentido de o rél ser conduzido ao laboratório, "debaixo de vara", para coleta do material indigpensável a feitura do exame DNA. A recusa resolve-se no plano furfaico-inatrumental. congideradas dogabicica, a doutrina e a -juxisprudincia, no que voltadas ao deglindo das questoros 1 igadas a prova dog fatos. (H.C. 72.373/RS - ReI. Min. FRANCISCO REZEK - DJ 20/21/1994 - PP-45.686)

E relatorio.

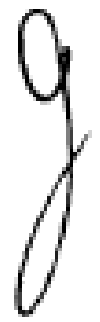




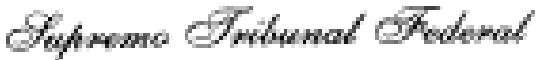

$B C 76060-4-B C$

\section{1}

표 $\mathrm{x}$ 은

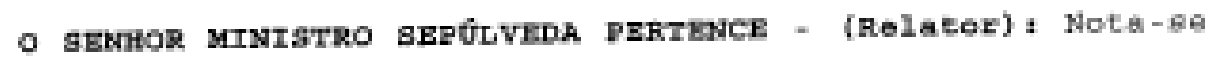
de logo gue o acordio plentixto evocado pelo paxecer da procuradoriaGeral - HC 71.373, 10.11.94, DJ 22.11.96 - , nAio ef da lavra do em. Ministro Rezek - relator originario, mas vencido - e sim do em. Ministro Marco Aurbilo.

Con. o notúvel voto vencido do Ministro Rezek, alinhamo-nos oe ema. Ministros Ilmar Galvao e Carlos Velloso e eu próprio, no gentido da possibilidade a conduçăo do investigado a colheita henática para o pesquias do DNa - malgrado decorrence da reduzidfanima invasăo a sua integridade fiaica -, en atença i prevalencia gue emprestanos ao "direito elementar que tem a pessoe de conbecer aua origom gen6tios" ou geja, "à sua real (e não prosuadda) 1dentidaden (Rezek).

- caso propieiou-me a ocasizo de colher informaçēes, posto que apressado, sobre o estado da questão no direito comparado.

Abstraías as conotaçōes erpecificas do problema no processo penal iv.g., f́ngel Gil hernandez, Intervenoioned Corporalen y Derechoe Fundamentales, Madrid, ed. Colex I995, Kichel Taruffo, Le prove ocientifiohe nella recente eoperienza otatunitenoe, Riv. It. Dir, Proc., Civile, 1996, n. 1/219); Daniela Vigoni, Corte Costiturionale, prolievo ematico e teat del Dar, Riv. It. Dir, Proe, Penale, 1996, 4/1.022), 6 de reconhecer que, no campo da invertigaço da paternidade, nos ordenamentos europeus de maior<smiles>C1CCCCC1</smiles> 


\section{Gupremo SFribusal OFdenat}

HC $76060=4-3 C$

\section{5}

trânsito entre nós - com a exceçăo da Alemanha - prevalece a teae que, no Tribunal, xeuniu a maioria.

"A Franç, a Italia e a Eapanha" - sintetiza Rainer Frazk (L'Bxamen Biologique soua Contrainte dans le Cadre de 1.gtabliagement on Droft Allemand, na Róvue internat. dx, conpare, 1995, n. 4/905, 909) - "se identificaw ex que a recusa de gubmeterse ao exame biologico näo tem consegelénclas senăo na apreciaçăo dag provas belo julz, ao passo que o direito inglis considera que a recusa a aujeltar-se d ardem fudicial gue ordena o exame corporal vale por obetruir a busca da prova e deve conduzir necesgariamente a perda do processo".

"Esca diferenca de valoraço de comportamentos semelhantes entre of slatemas juridicos de influţcia romaniata, de uma parte, e - siatema juridico ingles, de outra parte, - proseggue aquele professor de Priburg - "encontra sua verdadeira explícaço no fato de que a França, a Italia e a Espanha obedecer aco prinefpios concernentes ao estado ds peasoa: um fulgamento sobre a filiaçắ produg efeitos erua ames e deve, por osaa raszo, ter en conta a verdade biológica, so passo que na Inglaterra as questósa atinentes ao direito da filiaçio săo sempre examitradas enquanto questóes prefudiefais autobnoms, incidentes, no ambito de procegsos de alimentos ou relativos a sucesabo*.

Dá conta o autor \{1b., p. 909\} de que no mesme grupo se situan, mutatia mutandia, o direito guiço e o austriaco.

A exceço mais notivel na Buropa ocidental e assim a Alemanba, onde vige, desde a reforma de 1939, a regra da submiasōo Q 


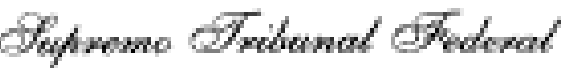

IIC $76060-4=8 C$

\section{6}

cotiva dae partes a dus testeminhas a colhetta do sangue, dese

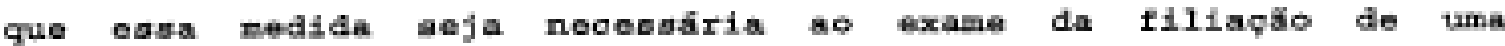
eriangas".

A fnovaça dota do auge do nacional socialiamo quando, por Eorca da politia rabial do regimo totalitario - note Frank lib-, P.

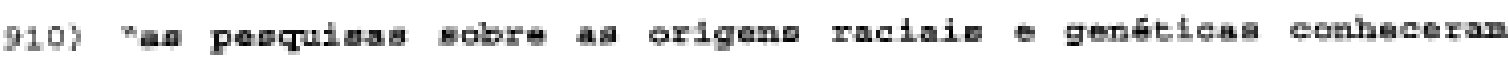
importaneia greacente", excedente do domfnio do direito da infancia teanto agala, informa, que a regra da lei proceasual civil fot estandida, am 1943, ase procedimontog administrativod de apuraça abmante de pertineneia a uma raça ou a un ciaj.

o intereseante, no entanto, aegundo atesta 0 juriata germanteo, \& que a regra da oompulaoriedade do exame, nab Fot entigmatizada, no apbs-guerta, como vinculada ao pensamento nazieta,

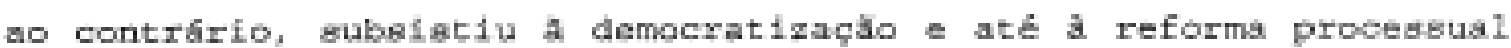
de 1950, justiflenda como decorrancia do principio inquibitstio que Aemina, no direito alemio, os procedimentou relativos a filiapáto: timalmente, a legitimidade do aimena veio a reforçar-ne con a afirmacto pelo Tribunal Conatitucionil Foderal, entre on direitog gerala da personalidsde, do "direlto ao conhocimento da origen

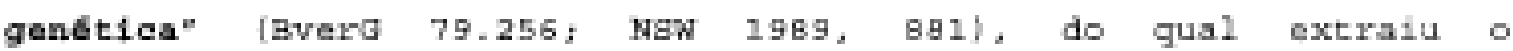

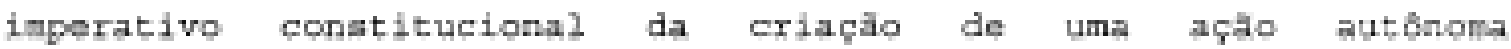
declarutoria da filiaço gendtion, nüo aujeita A limitapoos da conteataçĭo da legitimidade preaunida: contra o que - Lnforma o autor - nas ae pbde antepor o direlto i integridade esrporal, en

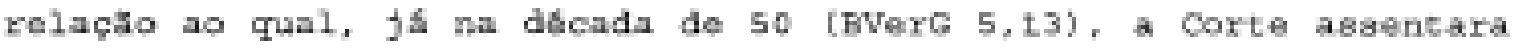
que manfeatamente noto a agride a colbeita de ura pequena quantidade de angue [Frank, 1b.. p. 911).

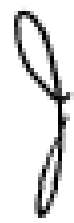


Sinilar, no ponto, ao alemblo 6 o direito norte-anericano $e$ - dos pafaes nordicos Frank, ob. loc. cit., p. 920; Marcelo Stalterl, Genetica e processo: la prova del "dna fingerprint", Riv. Trimegtr. Dix, e Proc., Civile, Ano XLvir, n. 1 (3.93), P. 189), nos Estados Unidos, informa stalteri (1b., p. 220), os ordenamentos estafuais têm adotado s regra do Uniforme Darentage Act, de 1973, 8. II, A, a teor Ga qual "the Court aay, and upon the requeat of a party ahall require the child, mother or alleged father to subnit to blood teata", sob pena de contempt of Cort e, pois, de aujeiçăo compulabria ao exame.

De minha parte, nato obstante o respeito a maioria formada no HC 71.313 e o dominio do seu entendimento no direito comparado, ainda nāo me animo a abandonar a corrente minoritaria no gentido explicito no meu voto vencido - de que năo se poce opor o minimo ou - para usar de expressão do eninente Ministro Relator - o risfvel Bacriffcio a inviolabilidade corporal /decorrente da "simplea ospetadela", a que alude o voto condutor do em. Ministro Marco Aurbilo) - *à eminênoia dos interesses onetitucionalmente tuteladoa à 1nventigaçio da propria patornidade* .

A digreaslo, entretanto - e com as mishas escusas - vale apenas o titulo de reacrva do eventual e oportuno reexame da tese do precedente lenbrado.

Na capécie, por certo, näo eata presentes as circunstincias - gue, atinentes ao aiteito fundamental a propria a real identidade genética - me induzen a insistir na ressalva prudente.

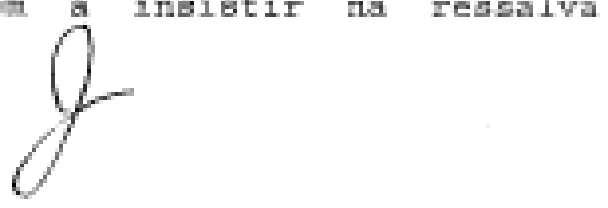


HC $76060-4=3 C$

\section{Gipremo EFribunal Fredexal}

\section{8}

Cuida-ae squi, cono visto, de hipbtese atipica, em gue o processo tem por objeto a pretemion de um terceiro de ver-se declarado pai da crisuç gerada na conetancia do ceasmento do paciente, que assim tem por ai a preaunçāo legal da paternidade e contra quem, por is8o, se dirige a açăo.

Nš discuto aqui a questāo civil da admisgibilidade da demsnda

o gue, entretanto, nas parece resistix, que naí não seja. ao confronto do princlpio da razoabtlidade ou da proporcionalidade de fundamental ioportaneia para o deslinde constitucional da coliesio de Aireitos fundamentais - E gue se pretenda constranger fiaicamente - pal presumido so fornecimento de uma prova de reforço contra a presunçăo de que é titular.

É de aublinhar que efetivamente se euidaria de simples prova de reforço de um fato que, de outro modo, ae pode comprovar.

Com efeito. A revolução, na irea da invertigaçlo da paternidade, da deacoberta do codigo gendtico individual, em relaça ao velho cotejo dos tipos sangùineos dos envolvidos, esta ent que o reaultado deste, se preatava apenas e eventualmente a exclusão Ga filiaça questionada, ao passo que o dNA leva asbidamente a reaultados positivos de indices probabilfoticos tendentes a certeza.

segue-se daf a prescindibilidade, em regra, de ordenada coaclo do paciente ao exame hematolbgico, a busca do excluato da sua paternidade presumida, quando a evidencia positiva da alegada B

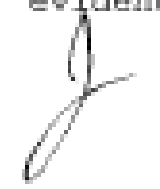


$76050=4=8 C$

Elupinemo STribunal frederal

\section{9}

paternicace genética do autor da demanda pode ser inveatigada sem a participaçio do rớcu ié expreasivo, aliks, que on autos ju contenham laudo particular de análise do DNA do autor, do menor e de sua mä $\mathrm{v}, 4 /(-853)$,

Base o quadro, o primeiro e mais alto obstáculo conetitucione1 a aubjugaça do paciente a tornar-ge abjeto da prova do DNA מă \& certasente a ofenaa da colheita de material, minimamente invasiva, a sua integridade fisica, mas sim a afronta a sua dignidade pessosl, que, nas circunstaneias, a participaçăo na periefa substantivaria.

De tudo, desiro a ordem para vedar definitivamente a produç̆o da prova guestionadan e o meu voto.

EBS/

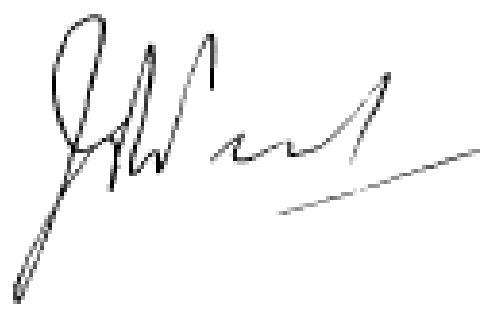




\section{Duprowo thribunal thedenal}

PRIMEIRA TURMA

\section{EXTRATO DE ATA}
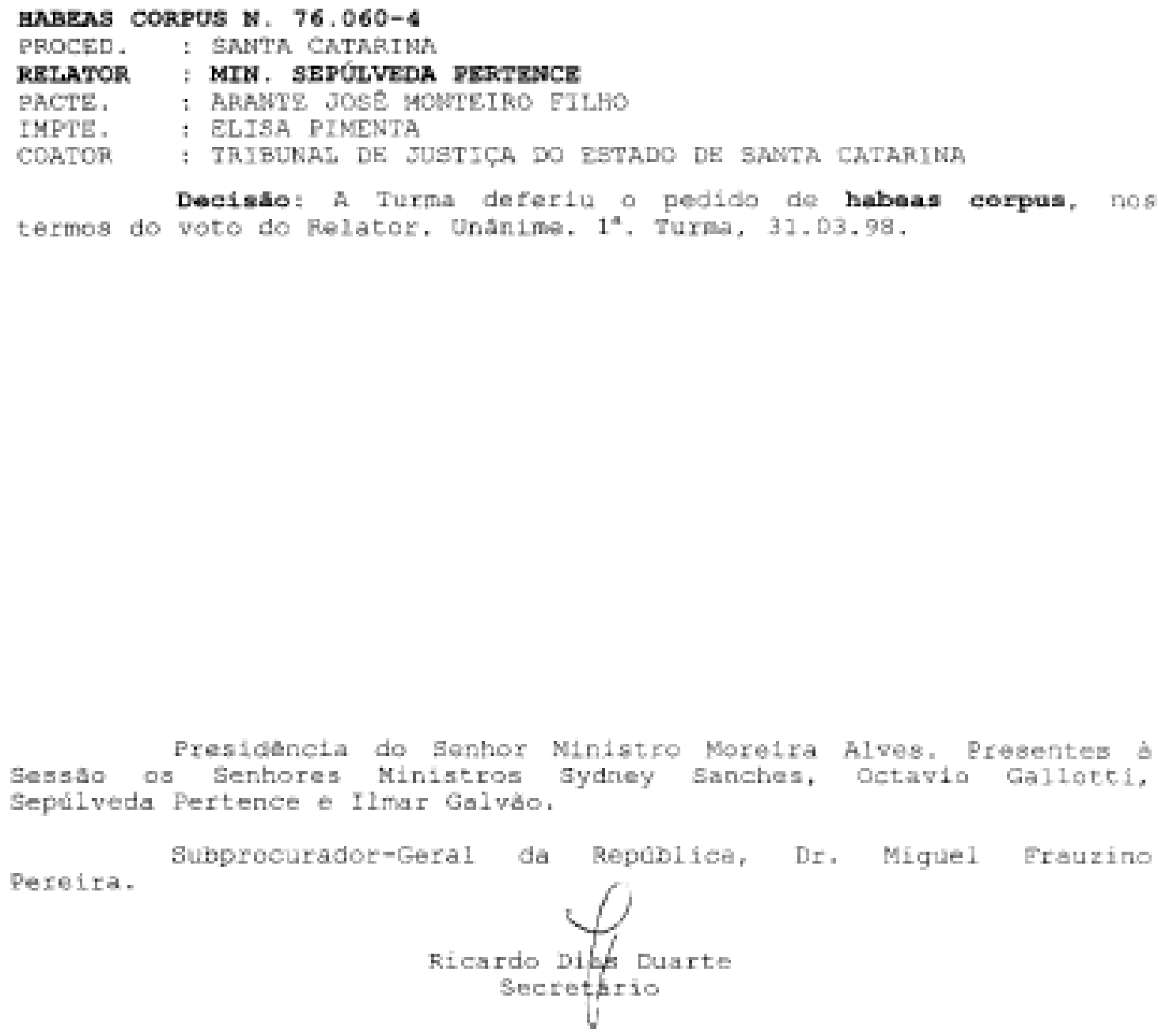